$12 / \mu^{1196}+2(4)$

\title{
Biotechnology for Removal of Carbon Disulfide Emissions: Final Report
}

Energy Systems Division Argonne National Laboratory

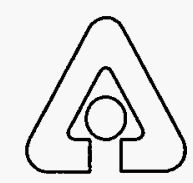

Operated by The University of Chicago, under Contract W-31-109-Eng-38, for the

United States Department of Energy

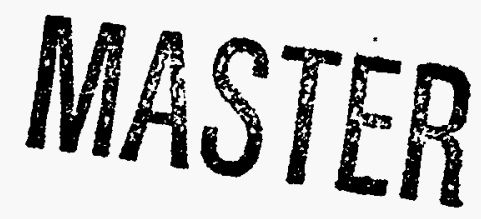




\section{Argonne National Laboratory}

Argonne National Laboratory, with facilities in the states of Illinois and Idaho, is owned by the United States Government, and operated by the University of Chicago under the provisions of a contract with the Department of Energy.

This technical report is a product of Argonne's Energy Systems Division.

For information on the division's scientific and engineering activities, contact:

Director, Energy Systems Division

Argonne National Laboratory

Argonne, Illinois 60439-4815

Telephone (708) 252-3724

Publishing support services were provided by Argonne's Information and Publishing Division (for more information, see IPD's home page: http://www.ipd.anl.gov/).

\section{Disclaimer}

This report was prepared as an account of work sponsored by an agency of the United States Government. Neither the United States Government nor any agency thereof, nor any of their employees, makes any warranty, express or implied, or assumes any legal liability or responsibility for the accuracy, completeness, or usefulness of any information, apparatus, product, or process disclosed, or represents that its use would not infringe privately owned rights. Reference herein to any specific commercial product, process, or service by trade name, trademark, manufacturer, or otherwise, does not necessarily constitute or imply its endorsement, recommendation, or favoring by the United States Government or any agency thereof. The views and opinions of authors expressed herein do not necessarily state or reflect those of the United States Government or any agency thereof.

Reproduced directly from the best available copy. Available to DOE and DOE contractors from the Office of Scientific and Technical Information, P.O. Box 62, Oak Ridge, TN 37831; prices available from (615) 576-8401.

Available to the public from the National Technical Information Service, U.S. Department of Commerce, 5285 Port Royal Road, Springfield, VA 22161. 


\section{Biotechnology for Removal of Carbon Disulfide Emissions: Final Report}

by M.J. Mclntosh

Energy Systems Division,

Argonne National Laboratory, 9700 South Cass Avenue, Argonne, Illinois 60439

July 1995

Work sponsored by United States Department of Energy, Assistant Secretary for Energy Efficiency and Renewable Energy 


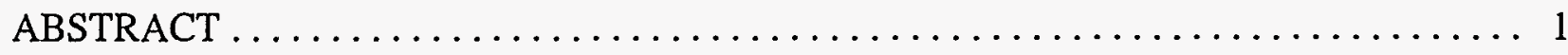

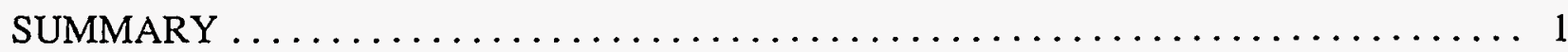

1 INTRODUCTION $\ldots \ldots \ldots \ldots \ldots \ldots \ldots \ldots \ldots \ldots \ldots \ldots \ldots \ldots \ldots \ldots \ldots \ldots \ldots \ldots \ldots$

2 BIOTECHNOLOGY FOR AIR PURIFICATION $\ldots \ldots \ldots \ldots \ldots \ldots \ldots \ldots$

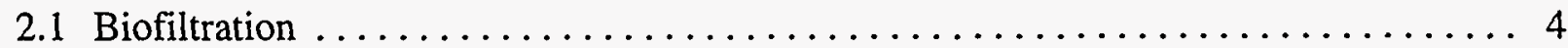

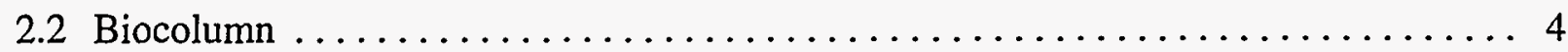

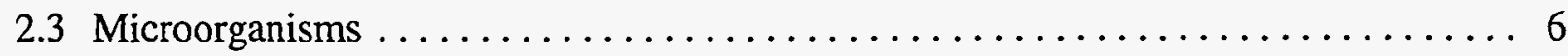

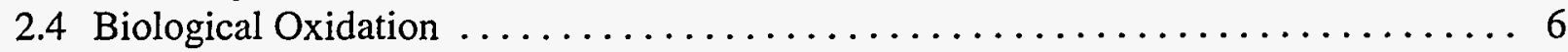

3 DISPOSAL OF BY-PRODUCTS $\ldots \ldots \ldots \ldots \ldots \ldots \ldots \ldots \ldots \ldots \ldots \ldots \ldots \ldots \ldots \ldots \ldots \ldots$

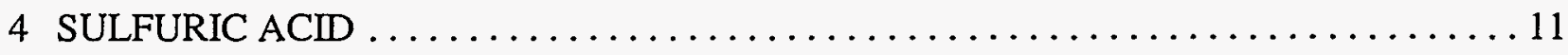

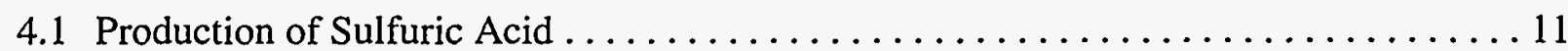

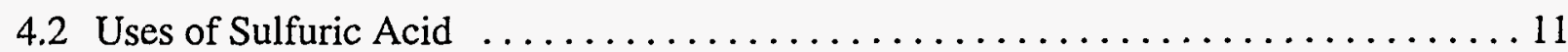

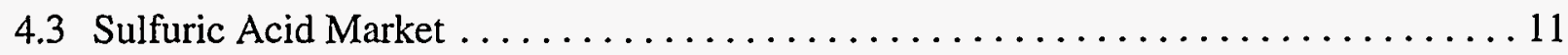

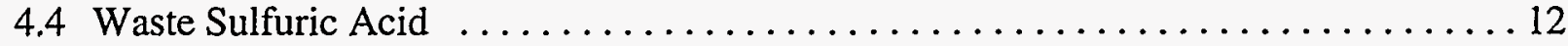

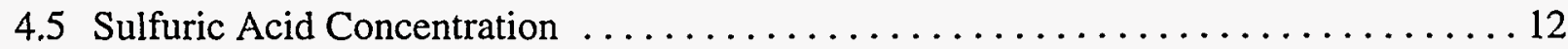

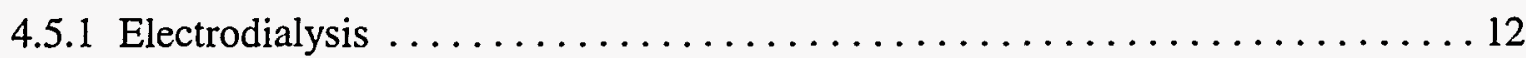

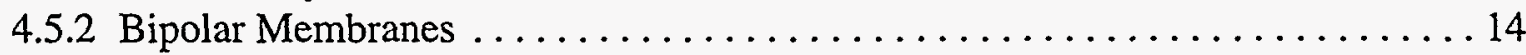

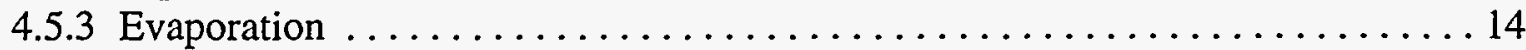

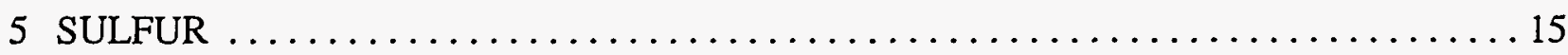

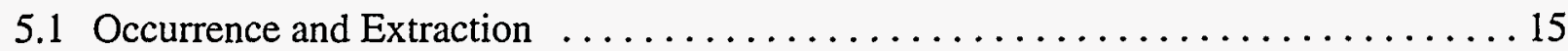

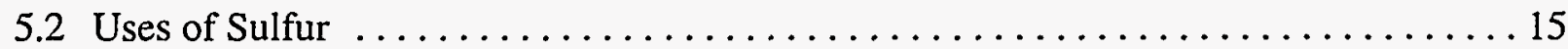

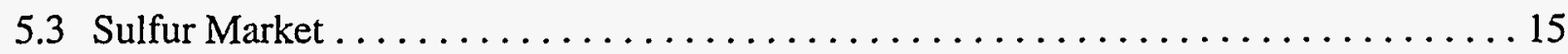

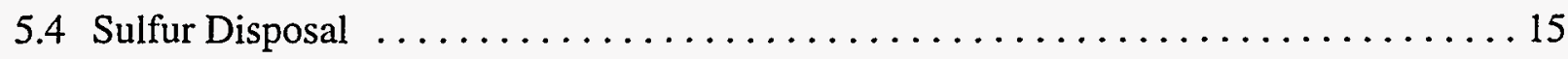

6 COST ESTIMATES FOR $\mathrm{CS}_{2}$ REMOVAL PROCESSES $\ldots \ldots \ldots \ldots \ldots \ldots \ldots \ldots$

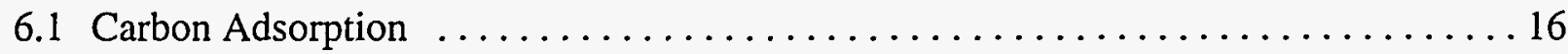

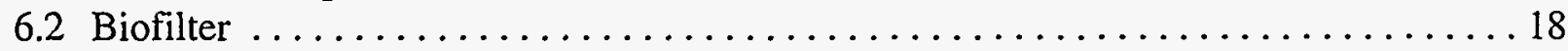

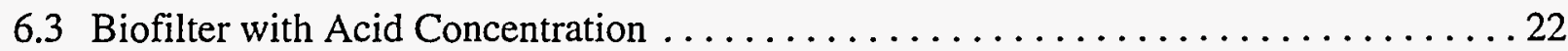

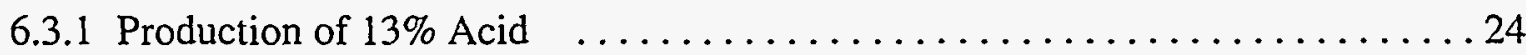

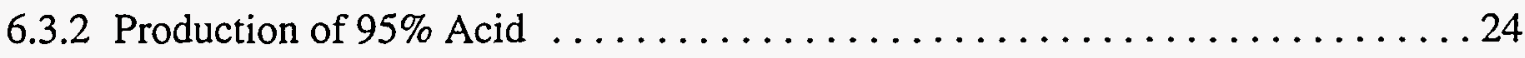

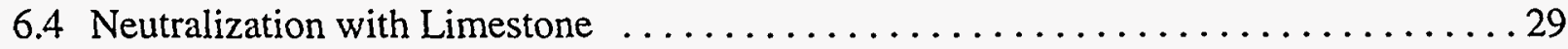

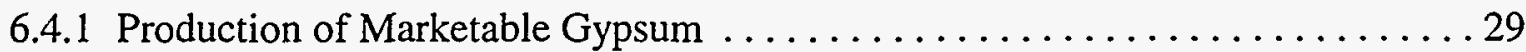

6.4 .2 Production of Waste Gypsum $\ldots \ldots \ldots \ldots \ldots \ldots \ldots \ldots \ldots \ldots \ldots \ldots \ldots \ldots \ldots$ 


\section{CONTENTS (Cont.)}

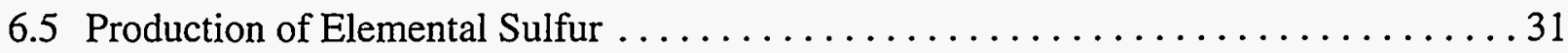

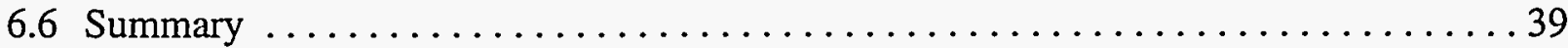

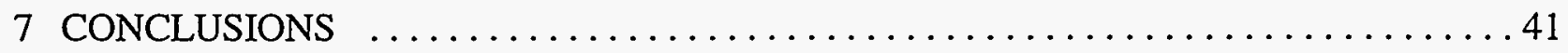

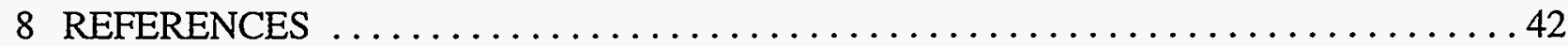

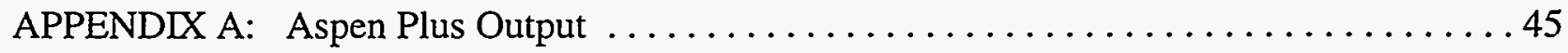

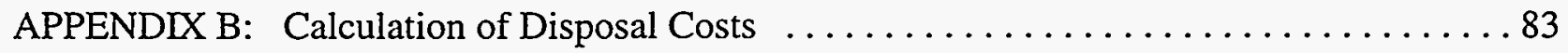

APPENDIX C: Calculations Used in Completing the Material Balance .............. 95

\section{TABLES}

1 Summary of Potential Sulfur and Sulfur Compounds Recovered from

Teepak Sources . . . . . . . . . . . . . . . . . . . . . . . . . . . . 9

2 Summary of Disposal Costs for Possible Wastes Produced at Teepak $\ldots \ldots \ldots \ldots \ldots 10$

3 Maximum Concentration Percentages for Different Methods of

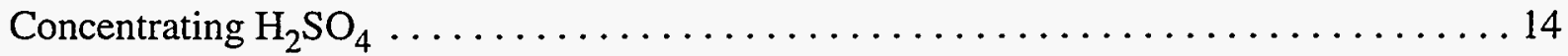

4 Summary of Simulation Results for a Carbon Adsorption Plant . . . . . . . . . . . . . 19

5 Assumptions for the Process and Economic Simulation for a Biofilter Plant . . . . . . 20

6 Summary of Simulation Results for a Biofilter Plant with 3\% Acid Waste $\ldots \ldots \ldots \ldots 23$

7 Operating Constants for Acid Concentration Plants $\ldots \ldots \ldots \ldots \ldots \ldots \ldots \ldots \ldots \ldots \ldots \ldots \ldots$

8 Summary of Simulation Results for a Biofilter Plant with Acid

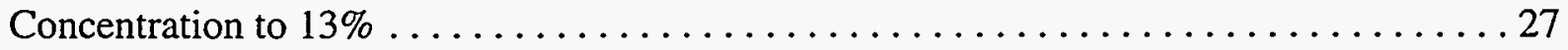

9 Summary of Simulation Results for a Biofilter Plant with Acid

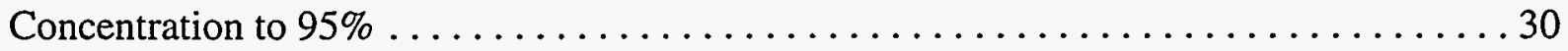

10 Summary of Simulation Results for a Biofilter Plant with Acid Concentration

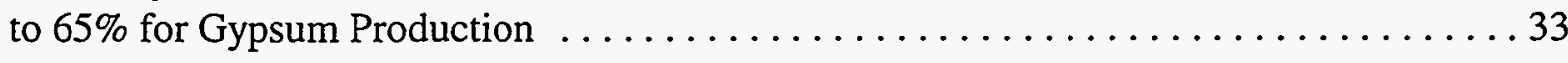




\section{TABLES (Cont.)}

11 Summary of Simulation Results for a Biofilter Plant with $3 \% \mathrm{H}_{2} \mathrm{SO}_{4}$

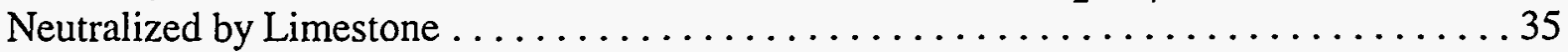

12 Summary of Simulation Results for a Biocolumn Producing Elemental Sulfur . . . . . 38

13 Summary of Costs for $\mathrm{CS}_{2}$ Removal Processes $\ldots \ldots \ldots \ldots \ldots \ldots \ldots \ldots \ldots$

\section{FIGURES}

1 Closed Modular Biofiltration Unit $\ldots \ldots \ldots \ldots \ldots \ldots \ldots \ldots \ldots \ldots \ldots \ldots \ldots \ldots \ldots \ldots$

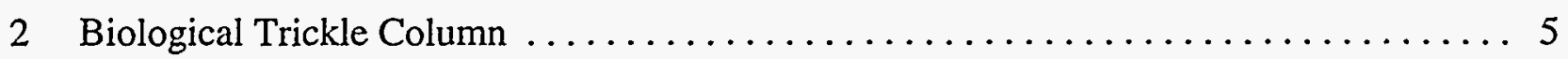

3 Process Flow Diagram of a Wastewater Treatment Facility $\ldots \ldots \ldots \ldots \ldots \ldots \ldots$

4 Process Flow Diagram for a Carbon Adsorption Plant $\ldots \ldots \ldots \ldots \ldots \ldots \ldots \ldots \ldots$

5 Configuration of One Double Unit of a Biofilter Field $\ldots \ldots \ldots \ldots \ldots \ldots \ldots \ldots \ldots \ldots$

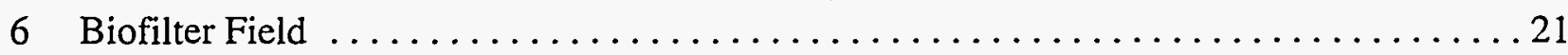

7 Process Flow Diagram for a Biofilter Plant $\ldots \ldots \ldots \ldots \ldots \ldots \ldots \ldots \ldots \ldots \ldots \ldots \ldots \ldots$

8 Biofiltration/Acid Concentration Plant for Producing $13 \%$ Acid $\ldots \ldots \ldots \ldots \ldots \ldots 25$

9 Biofiltration/Acid Concentration Plant for Producing $95 \%$ Acid $\ldots \ldots \ldots \ldots \ldots \ldots 28$

10 Process Flow Diagram for a Gypsum Plant $\ldots \ldots \ldots \ldots \ldots \ldots \ldots \ldots \ldots \ldots \ldots \ldots \ldots \ldots \ldots$

11 Process Flow Diagram for a Biofilter Plant with Gypsum Production for Disposal . . . . 34

12 Process Flow Diagram for a Biocolumn Plant $\ldots \ldots \ldots \ldots \ldots \ldots \ldots \ldots \ldots \ldots \ldots \ldots \ldots$

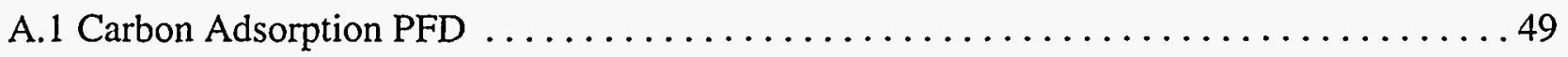

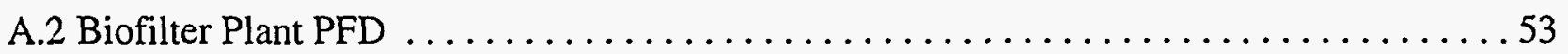

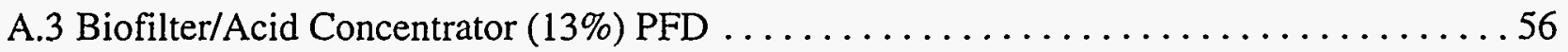

A.4 Biofilter/Acid Concentrator (95\%) PFD $\ldots \ldots \ldots \ldots \ldots \ldots \ldots \ldots \ldots \ldots \ldots \ldots \ldots \ldots \ldots \ldots \ldots$ 
FIGURES (Cont.)

A.5 Biofilter/Acid Concentrator (65\%)/Gypsum Production PFD $\ldots \ldots \ldots \ldots \ldots \ldots$

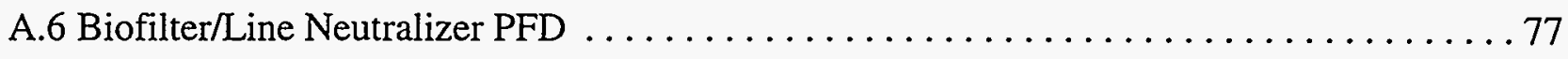

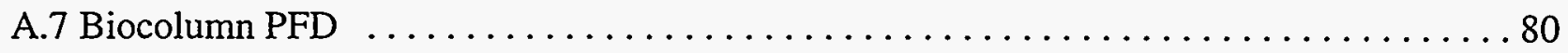




\title{
BIOTECHNOLOGY FOR REMOVAL OF CARBON DISULFIDE EMISSIONS: \\ FINAL REPORT
}

by

\author{
M.J. McIntosh
}

\begin{abstract}
Biological removal in a "biofilter" plant of carbon disulfide and hydrogen sulfide from the air effluent of a viscose plant at Teepak, Inc., is analyzed from process and economic standpoints by use of the Aspen Plus simulation program. The metabolic product from the biofilter, $3 \%$ sulfuric acid, must be transformed at the source into either a marketable or recyclable commodity (such as $95 \%$ sulfuric acid, high-quality sulfur, or high-quality gypsum) or a material with reasonable landfill costs (such as sulfur or gypsum). The simulations indicate that the total capital requirement for production of concentrated sulfuric acid is $\$ 48.9$ million; for high-quality gypsum, $\$ 40.4$ million; and for high-quality sulfur, $\$ 29.4$ million. Production of concentrated sulfur for landfill is not economically practical. The process to neutralize the $3 \%$ acid effluent with limestone and landfill the resulting lowquality gypsum requires the lowest total investment of the processes simulated, $\$ 8.7$ million, including the biofilter plant.
\end{abstract}

\section{SUMMARY}

A viscose plant operated by Teepak, Inc., produces approximately $644,000 \mathrm{~m}^{3} / \mathrm{h}$ of waste air contaminated with $293 \mathrm{mg}$ of $\mathrm{CS}_{2}$ and $146 \mathrm{mg}$ of $\mathrm{H}_{2} \mathrm{~S}$ per cubic meter. The $\mathrm{H}_{2} \mathrm{~S}$ is currently being removed by alkali scrubbing, but the $\mathrm{CS}_{2}$ is emitted to the atmosphere. Biological removal of these contaminants is analyzed from process and economic standpoints. A "biofilter" plant is estimated to consist of a field of 104 large porous beds or biofilters. One acre of area is required, assuming the biofilter units are double-stacked. Each biofilter treats a portion of the air by passing it through a bed of organic material and activated carbon that is saturated with the sulfurmetabolizing bacteria, thiobacillus. A recycling solution carries the metabolic product, $3 \%$ sulfuric acid, from the biofilter to other processing units. 
The $3 \%$ sulfuric acid has no commercial value and cannot be disposed of at a reasonable cost. If the biofilter is to be used, the dilute acid must be transformed at the source, either into a marketable or recyclable commodity or into a material less costly to dispose of than acid. Possible marketable commodities are concentrated sulfuric acid (95\%), high-quality sulfur, and high-quality gypsum. Possible materials with reasonable landfill costs are sulfur and gypsum.

The production of concentrated acid and high-quality gypsum requires acid concentration by evaporation. Budget estimates $( \pm 30 \%)$ indicate that the total capital requirements for these processes are $\$ 48.9$ million (acid) and $\$ 40.4$ million (gypsum). For comparison, a carbon adsorption plant for $\mathrm{CS}_{2}$ removal would have a total capital requirement of $\$ 31.6$ million (calculated by using the same estimating methods).

It is possible for a marketable high-quality sulfur to be produced in a packed column containing surfaces saturated with thiobacillus. The total capital requirement is estimated to be $\$ 29.4$ million. Production of concentrated sulfur for landfill is not economically practical.

To neutralize the 3\% acid effluent from a biofilter plant with powdered limestone, by using a simple stirred-tank reactor followed by a clarifier, may require a total investment as low as $\$ 8.7$ million, including the biofilter plant. The resulting low-quality gypsum product is sent to a landfill. Because of the relatively low estimated cost, this option is recommended for further, more detailed, process and economic study. 


\section{INTRODUCTION}

A plant in Danville, Illinois, operated by Teepak, Inc., manufactures cellulose food casings by means of the viscose process (a well-known process for producing such cellulose polymeric materials as food casings, rayon, etc.). Approximately $644,000 \mathrm{~m}^{3}$ of ventilation air is emitted from the plant per hour. Prior to scrubbing, this airstream is contaminated with about $293 \mathrm{mg}$ of $\mathrm{CS}_{2}$ and $146 \mathrm{mg}$ of $\mathrm{H}_{2} \mathrm{~S}$ per cubic meter. Caustic scrubbing removes the $\mathrm{H}_{2} \mathrm{~S}$ but not the $\mathrm{CS}_{2}$. The Clean Air Act Amendments of 1990 require that these $\mathrm{CS}_{2}$ emissions eventually be eliminated or greatly reduced.

Argonne National Laboratory has previously studied the possibility of using currently available, well-known, gas cleanup methods, including adsorption and absorption, to remove the $\mathrm{CS}_{2}$ [1]. Common absorption and incineration were found to be either infeasible or very expensive. Carbon adsorption was found to be effective and less expensive and, therefore, was a possibility. This current study is a supplement to the previous study. Instead of focusing on well-known, proven methods, this study considers less well-known, bacterial-based methods, emphasizing comparative cost estimates.

In particular, two slightly different bacterial-based processes are under consideration for cleaning the Teepak airstream. Both use the sulfur-metabolizing bacteria, thiobacillus, to oxidize and thereby destroy the airborne sulfide contaminants $\mathrm{H}_{2} \mathrm{~S}$ and $\mathrm{CS}_{2}$. In one case, certain conditions (discussed in Section 2.4) are controlled to force the reaction to near 100\% oxidation of the sulfide, producing sulfate (i.e., sulfuric acid). In the other case, it is assumed that complete oxidation can be discouraged, and much less of the sulfide is converted to sulfate; most of the sulfur in the sulfides becomes elemental sulfur. Representative processes for these two cases are simulated in detail, and economic models of the processes are presented (see Appendix A for a detailed explanation of the costing application of Aspen Plus, a well-known simulator). In this report, the term "biofiltration" is used for the process that oxidizes to sulfate, and the term "biocolumn" is used for the process that produces mostly elemental sulfur.

Ancillary processes for sulfuric acid concentration and gypsum production are also evaluated in various combinations with the biological processes. Process simulation is used to select the most economically feasible means of removing sulfide gases from the Teepak air, while minimizing disposal costs of sulfur-based by-products. 


\section{BIOTECHNOLOGY FOR AIR PURIFICATION}

\subsection{BIOFILTRATION}

Biofiltration is defined as the removal and oxidation of organic gases (or such inorganic gases as $\mathrm{H}_{2} \mathrm{~S}$ and $\mathrm{CS}_{2}$ ) from contaminated air by microorganisms in a "filter" or bed of porous compost or soil. It is a relatively new technique for reducing industrial emissions of polluted air. The first biological air filters appeared in the 1950s and were used to treat odorous air from compost factories and sewage-water treatment plants. With the development of new biologically active materials in the late 1970s, the applicability of biofiltration has expanded [2].

Recently, a closed-type modular biofiltration unit, or "biofilter," has been developed. This unit is illustrated in Figure 1. Polluted air is conducted via a pressure chamber through a porous filter (i.e., a layer of biologically active material approximately $1-\mathrm{m}$ thick). The filter material is continuously sprayed from above with a recycled-water solution to provide nutrients and to maintain filter moisture content between 60 and $70 \mathrm{wt} \%$. The filter material comprises a mixture of selected tree bark, compost, microorganisms, and adsorbents (e.g., activated carbon). This mixture forms an optimal environment for selected microorganisms. Within the filter, the microorganisms attach to all surfaces, forming a layer of microbial life called the "biolayer."

Contaminants and oxygen are transported by diffusion through the biolayer from the gas/liquid interface to the microorganisms. Inorganic nutrients necessary for microbial life are also supplied. Contaminants (such as sulfides) are taken up by the microorganisms, which use the contaminants for growth and other metabolic activities, and the oxidized form is excreted.

The applicability of biofiltration is increasing continually. The number of contaminant chemicals that can be treated successfully, as well as the number of installations, is increasing yearly. This growth is not only due to increased applicability but also due to increasing knowledge of the biodegradation process.

\subsection{BIOCOLUMN}

In the biological trickle column (biocolumn) configuration, a vertical cylinder is filled with a relatively large-size plastic or ceramic packing, e.g., the packing rings shown in Figure 2. The microorganisms form a surface biolayer on the packing. A recycled-water solution of controlled $\mathrm{pH}$, containing dissolved bacterial nutrients, flows downward. Contaminated air passes upward, where the biolayer removes the contaminants [3]. In the case of $\mathrm{H}_{2} \mathrm{~S}$ and $\mathrm{CS}_{2}$ contaminants, autotrophic 


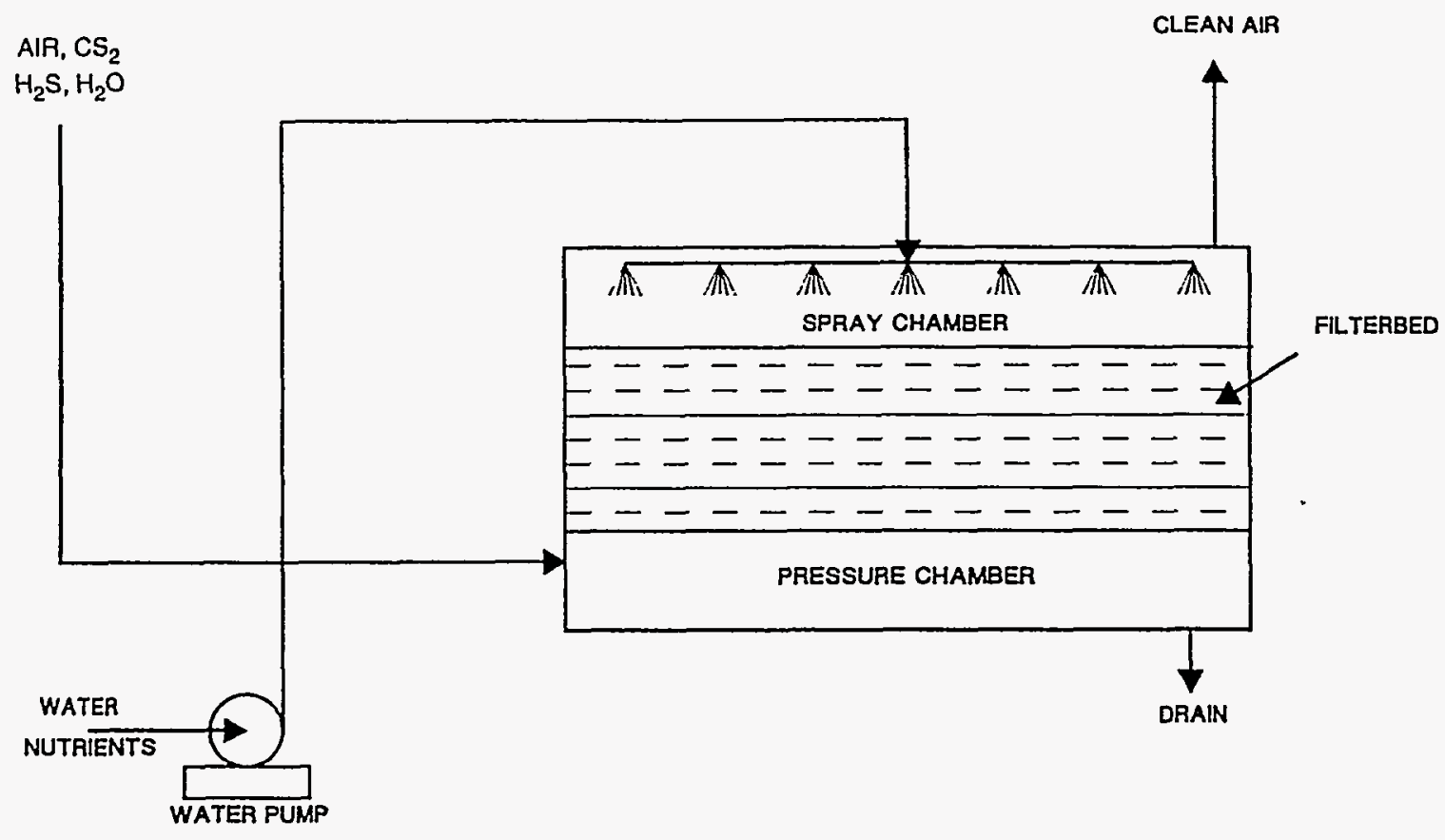

FIGURE 1 Closed Modular Biofiltration Unit

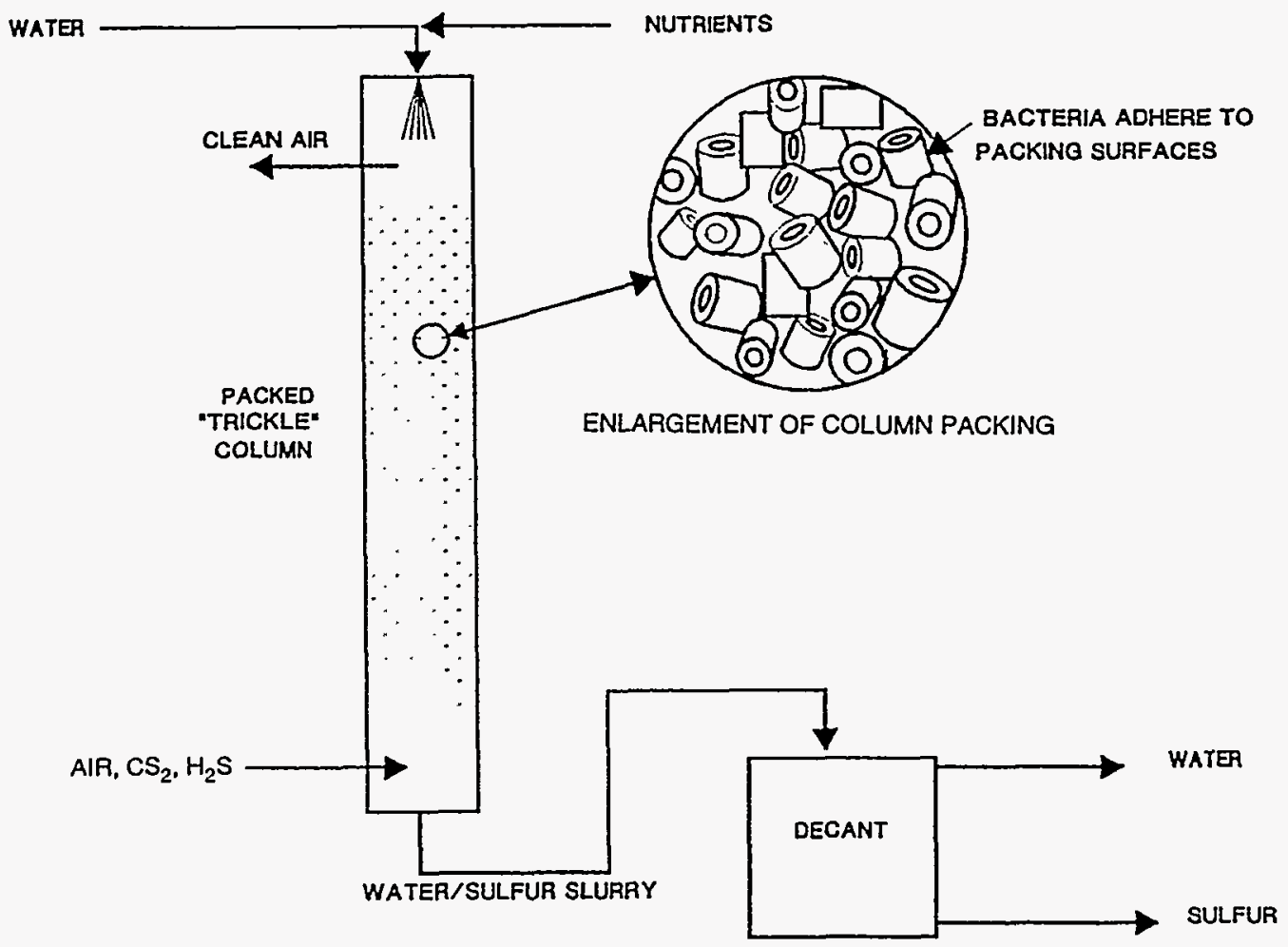

FIGURE 2 Biological Trickle Column (Biocolumn) 
bacteria of genus Thiobacillus are used. When the $\mathrm{pH}$ is maintained near neutral, large amounts of sulfur are produced, which exit the reactor as colloidal-sized particles [3]. This sulfur is carried through the column by the recycle liquid. If a favorable environment in the biocolumn is maintained, the biolayer can last for years with relatively little loss of microorganisms.

\subsection{MICROORGANISMS}

Many common soil bacteria can oxidize reduced sulfur compounds like $\mathrm{CS}_{2}$ and $\mathrm{H}_{2} \mathrm{~S}$. Some bacteria do this oxidation aerobically (in the presence of air), and others do it anaerobically (in the absence of oxygen). These microbes comprise both heterotrophic (obtaining nourishment from organic substances) and autotrophic (obtaining nourishment by synthesis of inorganic materials) types. Both types have been studied for biological removal of sulfur contaminants from water and air, but most of the work to date has been centered on autotrophic species, especially those of the genus Thiobacillus, which use reduced sulfur compounds as electron donors and carbon dioxide as a carbon source.

In some cases, the microbial population is composed of mixed cultures that have been enriched from common ditch mud [4]. In other cases, pure strains have been used [5]. Several studies have shown the applicability of mixed cultures grown from sewer sludge [3]. In particular, Thiobacillus denitrificans has been used to reduce $\mathrm{H}_{2} \mathrm{~S}$ under a variety of conditions [5]. This microbe has also shown a tolerance for $\mathrm{CS}_{2}$. In only a few cases have these biological methods been directly applied in $\mathrm{CS}_{2}$ removal from air emissions from a viscose plant [6].

\subsection{BIOLOGICAL OXIDATION}

The inorganic oxidation of sulfide in thiobacilli appears to proceed through three sequential reactions:

$$
\begin{gathered}
2 \mathrm{HS}^{-}+\mathrm{O}_{2} \rightarrow 2 \mathrm{OH}^{-}+2 \mathrm{~S}^{\circ}(\text { membrane bound }) \\
\left.\left.\mathrm{S}^{o} \text { (membrane bound }\right) \rightarrow \mathrm{S}^{\circ} \text { (extracellular }\right) \\
\left.2 \mathrm{~S}^{\circ} \text { (membrane bound }\right)+4 \mathrm{O}_{2} \rightarrow 2 \mathrm{SO}_{4}=+2 \mathrm{H}^{+}
\end{gathered}
$$

The economics of producing free sulfur, compared to the economics of producing sulfuric acid, depend on many variables, and separate evaluation of each individual case is necessary. Therefore, relative to the above three-stage reaction, two issues are pertinent: First, how can the three 
reactions be controlled, thereby controlling the relative yields of free sulfur and sulfuric acid? Second, how can possible by-products, such as free sulfur or sulfuric acid, best be recovered from the reactor and prepared for potential users?

A small amount of work has been done to address the first issue. In one study, which used a water-based, stirred gas/liquid reactor, it was concluded for thiobacillus that the third reaction can be suppressed by controlling oxygen and sulfide concentrations [4]. At high sulfide concentrations (exceeding $20 \mathrm{mg} / \mathrm{L}$ ), the second reaction was suppressed by the sulfide itself, so high oxygen concentration can be used to increase oxidation rates; at lower sulfide concentrations, the second reaction can be suppressed by increasing oxygen concentration.

Another study found that the relative rates of reactions 1 and 3 are different for different strains of thiobacillus [5], and these different strains require different acidities of the recycle solution to thrive [3]. The strains that favor reaction 1 thrive at neutral $\mathrm{pH}$, so maintenance of the bioreactor at $\mathrm{pH} 6$ or 7 will eventually eliminate strains that favor reaction 3 , and the production of elemental sulfur will be enhanced.

Some aspects of the recovery of by-products are addressed in detail in Section 6, where it is assumed that sulfuric acid can be recovered from the biofilter in dilute solution and that elemental sulfur can be recovered from the biocolumn. However, the recovery of elemental sulfur is less certain. Some researchers have stated that it is impossible to separate biomass and sulfur in a stirred reactor [4]. However, nonstirred experiments indicate that colloidal sulfur is indeed excreted by the bacteria and can be recovered from a packed, washed column [3]. Furthermore, the bacteria will remain in the column as long as favorable conditions are maintained. Therefore, the removed sulfur is not highly contaminated with bacteria cells. This concept has been described and patented by Torres-Cardona, et al. [7] and discussed by Cork [8]. 


\section{DISPOSAL OF BY-PRODUCTS}

As mentioned in the Introduction, approximately $644,000 \mathrm{~m}^{3} / \mathrm{h}$ of sulfide-contaminated air is emitted at Teepak. The $\mathrm{CS}_{2}$ levels are around $293 \mathrm{mg} / \mathrm{m}^{3}$. Caustic scrubbers currently remove about $9.4 \times 10^{7} \mathrm{mg}$ of $\mathrm{H}_{2} \mathrm{~S}$ per hour from this air. If all sulfur, including that of the $\mathrm{H}_{2} \mathrm{~S}$ currently removed by caustic scrubbing, were collected as elemental sulfur, about 2,392 tons of sulfur would be produced per year. This section covers generalized possibilities for disposal of either recovered sulfur or compounds that can be made from it; that is, the scope of the disposal problem is estimated and discussed without regard to how the sulfides are recovered from air and how the resulting sulfur compounds are processed. ${ }^{1}$ Also in this section, and in Appendix B, disposal costs are developed for possible sulfur compounds considered as wastes. Some possible forms of the recovered sulfur are (1) high-quality sulfur, (2) concentrated sulfuric acid, (3) dilute sulfuric acid, and (4) gypsum.

If all the sulfur were oxidized to sulfate, about 7,307 tons of sulfuric acid per year would be produced. Assuming $4 \%$ losses, collection possibilities for elemental sulfur and pure sulfuric acid become, respectively, 4.59 million pounds or 2,296 tons of sulfur per year and 14.0 million pounds or 7,015 tons of acid per year. If the sulfuric acid were obtained in a dilute form (such as 3\%), about 233,830 tons of dilute acid per year would be produced. If the acid were obtained at $13 \%$, about 53,961 tons of dilute acid per year would be produced. If the sulfur were contained in gypsum, about 12,351 tons of gypsum per year would be produced. Calculations to obtain these numbers are detailed in Appendix B. Table 1 summarizes the results.

Since sulfur is considered a nonhazardous waste and can be safely landfilled, it is possible that the sulfur recovered from the Teepak emissions could be disposed of in a relatively inexpensive, special-waste landfill. The costs for disposal of elemental sulfur, along with the other possible products, are estimated in Appendix B and summarized in Table 2.

The sulfuric acid produced by removing $\mathrm{H}_{2} \mathrm{~S}$ and $\mathrm{CS}_{2}$ emissions could be sent to a treatment facility, where it would be neutralized and the solids sent to a landfill for disposal. Likewise, the sulfuric acid could be reacted with limestone to produce gypsum that would be disposed of in a special-waste landfill. The disposal costs for sulfuric acid and gypsum are listed in Table 2.

1 In Section 6 of this report, the problem of how the sulfides may be recovered and processed to other forms that may be sold or disposed of is considered, and economic estimates are developed. Therefore, in some cases in Section 6, the various possible recovered sulfur compounds are assumed to be valuable commodities, revenue from their sales is estimated, and this estimate is used as a component of the economics. In other cases, the production of a disposable substance is evaluated. 
TABLE 1 Summary of Potential Sulfur and Sulfur Compounds Recovered from Teepak Sources

\begin{tabular}{|c|c|c|c|c|c|c|c|c|c|}
\hline \multirow[b]{2}{*}{ Source } & \multicolumn{3}{|c|}{ Rate of Emission } & \multirow[b]{2}{*}{$\begin{array}{c}\text { Sulfur } \\
\text { Recovery } \\
(\%) \\
\end{array}$} & \multirow{2}{*}{$\begin{array}{l}\text { Potential } \\
\text { Recovered } \\
\text { Sulfur } \\
\text { (tons/yr) }\end{array}$} & \multirow{2}{*}{$\begin{array}{c}\text { Potential } \\
100 \% \\
\text { Sulfuric Acid } \\
\text { (tons/yr) } \\
\end{array}$} & \multirow{2}{*}{$\begin{array}{c}\text { Potential } \\
\text { 13\% Sulfuric } \\
\text { Acid } \\
\text { (tons/yr) }\end{array}$} & \multirow{2}{*}{$\begin{array}{l}\text { Potential } \\
\text { 3\% Sulfuric } \\
\text { Acid } \\
\text { (tons/yr) }\end{array}$} & \multirow[b]{2}{*}{$\begin{array}{r}\text { Potential } \\
\text { Gypsum } \\
\text { (tons/yr) }\end{array}$} \\
\hline & $\begin{array}{c}\text { Air } \\
\left(10^{3} \mathrm{~m}^{3} / \mathrm{h}\right)\end{array}$ & $\begin{array}{c}\mathrm{CS}_{2} \\
\left(\mathrm{mg} / \mathrm{m}^{3}\right) \\
\end{array}$ & $\begin{array}{c}\mathrm{H}_{2} \mathrm{~S} \\
\left(\mathrm{mg} / \mathrm{m}^{3}\right)\end{array}$ & & & & & & \\
\hline Teepak 1 & 290 & 293 & 320 & 96 & $1,484.1$ & $4,532.4$ & $34,872.3$ & $151,111.5$ & $7,981.9$ \\
\hline Teepak 2 & 354 & 293 & 0 & 96 & 812.4 & $2,482.5$ & $19,089.2$ & $82,718.8$ & $4,369.3$ \\
\hline Total & 644 & & & & $2,296.5$ & $7,014.9$ & $53,961.5$ & $233,830.3$ & $12,351.2$ \\
\hline
\end{tabular}


TABLE 2 Summary of Disposal Costs for Possible Wastes Produced at Teepak

\begin{tabular}{|c|c|c|c|c|}
\hline \multirow[b]{2}{*}{ Item } & \multicolumn{4}{|c|}{ Waste Type } \\
\hline & $\begin{array}{c}3 \% \mathrm{H}_{2} \mathrm{SO}_{4} \\
\text { Solution }\end{array}$ & $\begin{array}{c}100 \% \\
\mathrm{H}_{2} \mathrm{SO}_{4}\end{array}$ & Gypsum & $\begin{array}{c}\text { Elemental } \\
\text { Sulfur }\end{array}$ \\
\hline $\begin{array}{l}\text { Amount produced } \\
\text { (tons/yr) }\end{array}$ & 233,830 & 7,015 & 12,351 & 2,296 \\
\hline \multicolumn{5}{|l|}{ Annual costs } \\
\hline Lab analysis & $\$ 1.3 \times 10^{3}$ & $\$ 1.3 \times 10^{3}$ & $\$ 2.8 \times 10^{3}$ & $\$ 2.8 \times 10^{3}$ \\
\hline Transport & $\$ 11.1 \times 10^{6}$ & $\$ 187.4 \times 10^{3}$ & $\$ 79.2 \times 10^{3}$ & $\$ 16.7 \times 10^{3}$ \\
\hline $\begin{array}{l}\text { Treatment } \\
\text { and landfill }\end{array}$ & $\begin{array}{c}\$ 32.9 \times 10^{6} \\
\text { to } \\
\$ 49.4 \times 10^{6}\end{array}$ & $\begin{array}{l}\$ 2.2 \times 10^{6} \\
\text { to } \\
\$ 2.8 \times 10^{6}\end{array}$ & $\$ 95 \times 10^{3}$ & $\$ 19.9 \times 10^{3}$ \\
\hline Taxes & $\$ 3.0 \times 10^{6}$ & $\$ 50.6 \times 10^{3}$ & $\begin{array}{l}\text { included in } \\
\text { treatment }\end{array}$ & $\begin{array}{c}\text { included in } \\
\text { treatment }\end{array}$ \\
\hline Total & $\begin{array}{c}\$ 47 \times 10^{6} \\
\text { to } \\
\$ 63.6 \times 10^{6}\end{array}$ & $\begin{array}{l}\$ 2.4 \times 10^{6} \\
\text { to } \\
\$ 3.0 \times 10^{6}\end{array}$ & $\$ 177 \times 10^{3}$ & $\$ 39.4 \times 10^{3}$ \\
\hline
\end{tabular}

Obviously, at a disposal cost approaching $\$ 63$ million per year, 3\% sulfuric acid is not a good choice for disposal. The disposal cost of pure sulfuric acid, at $\$ 3.05$ million, is only a fraction of the cost for dilute acid disposal, but, as discussed in Section 4, concentrated acid production is financially infeasible. However, Teepak uses concentrated sulfuric acid, currently worth around $4.0 \phi / \mathrm{lb}$, as a purchased commodity for the process. For example, in 1991, 15.55 million pounds of concentrated sulfuric acid were purchased, and in 1992, 16.11 million pounds were purchased. Therefore, it is possible that weak sulfuric acid produced by biofiltration recovery of $\mathrm{CS}_{2}$ and $\mathrm{H}_{2} \mathrm{~S}$ emissions, with subsequent concentration, could be entirely consumed at Teepak by recycle to the viscose process. Sulfuric acid is neutralized by sodium hydroxide in the viscose process, and, at Teepak, the majority of the resulting sodium sulfate is recrystallized and sold as a by-product.

From the above discussion, it is clear that disposal costs, especially for acid, are very high. The idea of marketing products from sulfide removal, especially sulfuric acid or elemental sulfur, seems sensible, since the sale of by-products would alleviate the expense of disposal and could possibly provide revenue. However, these and other alternatives cannot be evaluated unless the total cost of each option is estimated on a comparable basis. Such cost estimates are considered directly in Section 6. Sections 4 and 5 discuss generalized information on sulfuric acid and elemental sulfur as commodities. 


\section{SULFURIC ACID}

\subsection{PRODUCTION OF SULFURIC ACID}

Sulfuric acid is the highest volume chemical produced in the United States, and by far the most widely used industrial chemical. About $75 \%$ of commercial sulfuric acid is produced by burning elemental sulfur and passing the resulting sulfur dioxide, with oxygen, over a vanadium pentoxide catalyst to oxidize it to sulfur trioxide. The absorption of sulfur trioxide by an acid/water system produces the final product. This process is called the "contact" process [9].

Other, similar means of producing sulfuric acid are related to an increasing need to limit environmental damage by sulfur oxides emissions [10]. Recovery of sulfur oxides from copper, zinc, or lead smelter gases and subsequent processing of the oxides to sulfuric acid currently provides over $10 \%$ of sulfuric acid production. Regeneration of spent acid (by combustion) and other environmental-based production account for most of the remaining production.

\subsection{USES OF SULFURIC ACID}

The production of phosphate fertilizers consumes at least $70 \%$ of yearly U.S. sulfuric acid production [11]. Phosphate rock is converted to phosphoric acid and calcium sulfates. Further processing of the acid with ammonia produces diammonium phosphate (DAP), the final product. Other uses of sulfuric acid include production of inorganic pigments, textile fibers, explosives, petroleum products, alcohols, pulp, paper, detèrgents, and other chemicals, as well as a leaching agent for ores, a pickling agent for iron and steel, and a component for lead storage batteries.

\subsection{SULFURIC ACID MARKET}

Overall growth in sulfuric acid consumption is expected to average about $0.5 \%$ per year through 1995 [12]. The 1991 production was 44.2 million tons in the United States. Also, 1.8 million tons were imported, largely by-products from Canadian smelters. The fertilizer industry has recently struggled with a worldwide oversupply of DAP [13-16]. Economic difficulties in important user countries (such as India and China) have intensified the problem [17]. However, even with a DAP recovery, the use of sulfuric acid is expected to decline in the fertilizer industry. Balancing this decline is the increasing use of sulfuric acid in leaching ore to obtain copper [18]. 


\subsection{WASTE SULFURIC ACID}

Sulfuric acid is considered a hazardous waste. Commercial treatment facilities for neutralization and disposal exist [19]. For example, Clean Harbors Environmental Services, Inc., of Chicago, Ill., neutralizes the acid with sodium hydroxide. Most of the inorganic impurities in the solution are precipitated. The water is separated from the solids and discharged to the sewage system. The solids, which are a mixture of inorganics and hydroxides, are dewatered by pressure filtration and transported to a landfill. The generalized waste treatment process at Clean Harbors is illustrated in Figure 3. The results of our study (Table 2) indicate that the cost of treating weak acid by this method is too high for consideration.

Sulfuric acid can also be neutralized by limestone to produce gypsum (calcium sulfate). The gypsum product may be disposed of or, if of high purity, sold. The neutralization proceeds according to the following reaction:

$$
\mathrm{CaCO}_{3}+\mathrm{H}_{2} \mathrm{SO}_{4} \rightarrow \mathrm{CaSO}_{4}+\mathrm{H}_{2} \mathrm{CO}_{3}
$$

This reaction is easy to maintain as long as there is a sufficient supply of limestone. However, if excess acid is applied to a bed of limestone, it will precipitate the calcium sulfate and deactivate the limestone bed. To avoid this problem, sulfuric acid must be applied to a limestone bed at a rate less than $5 \mathrm{gpm} / \mathrm{ft}^{2}$ (gpm is gallons per minute) and be diluted to an upper limit of about $5 \%$ [20,21]. Reacting powdered limestone in a large stirred reactor may alleviate the deactivation problem, but it will not assure quality control of the gypsum produced. Gypsum disposal is a disadvantage of this method of neutralization. The costs associated with gypsum disposal and neutralization and with disposal of sulfuric acid are listed in Table 2.

\subsection{SULFURIC ACID CONCENTRATION}

Since biological treatment of $\mathrm{CS}_{2}$-laden air produces a weak sulfuric acid that has no market value and carries a very large disposal liability, concentration to a strong acid must be considered. Some of the various means of acid concentration are reviewed below. The maximum concentrations that can be attained with these methods are listed in Table 3.

\subsubsection{Electrodialysis}

Electrodialysis technology incorporates a succession of cation exchange membranes and an anion-exchange membrane placed between a pair of electrodes. The ions pass through the membranes in preference to all other species due to the voltage difference. Electrodialysis will not 


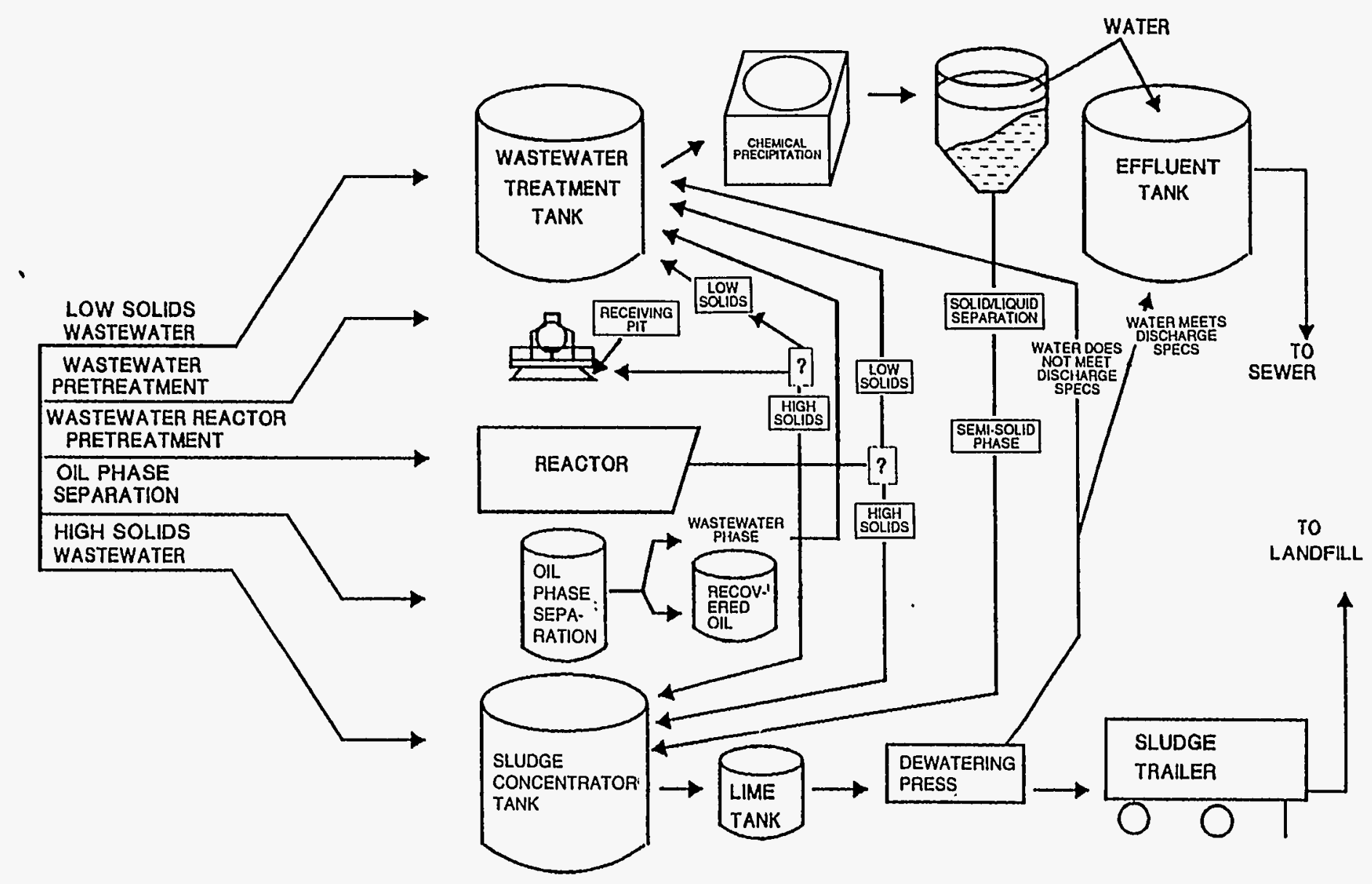

FIGURE 3 Process Flow Diagram of a Wastewater Treatment Facility 
concentrate sulfuric acid solutions above 5\%, because above $5 \%$ the concentration gradient between the cells is large enough that the cationexchange membrane passes $\mathrm{H}^{+}$ion due to osmotic pressure. Ionics, Inc., has done research with acidblocking membranes in acid concentrations above 5\% [22]. Unfortunately, the development was not fully successful; therefore, acid-blocking membranes have never been commercialized.
TABLE 3 Maximum Concentration Percentages for Different Methods of Concentrating $\mathrm{H}_{2} \mathrm{SO}_{4}$

\begin{tabular}{lc}
\hline $\begin{array}{c}\text { Method of } \\
\text { Concentrating } \\
\mathrm{H}_{2} \mathrm{SO}_{4}\end{array}$ & $\begin{array}{c}\text { Practical } \\
\text { Maximum } \\
\text { Concentration (\%) }\end{array}$ \\
\hline Bipolar Membrane & 10 \\
Electrodialysis & 5 \\
Evaporation & 95 \\
\hline
\end{tabular}

\subsubsection{Bipolar Membranes}

Graves Water Division, formerly Aquatech Systems, a business unit of Allied Signal Inc., has commercialized the use of electrodialysis with bipolar membrane technology [23]. This technology uses a stack of water-splitting cells placed between an electric potential to separate and concentrate the ions in a solution. Each water-splitting cell consists of three compartments - acid, salt, and base - which are bounded by the bipolar, anion, and cation membranes. The bipolar membrane, which contains a cation-selective region and an anion-selective region separated by a very thin interface, is the heart of the water-splitting cell. The water-splitting cell is placed between a pair of electrodes, with the cation-selective side toward the cathode. When an electric potential is placed across the electrodes, the cations and anions move across the monopolar membranes into their respective compartments. Bipolar membranes will not concentrate sulfuric acid solutions above $10 \%$, because the anion exchange membrane is not perfectly selective to the $\mathrm{H}^{+}$ions.

\subsubsection{Evaporation}

Evaporation is the removal of a solvent from a solution by vaporization of the solvent. It represents the most common method of concentration of dilute sulfuric acid and the only practical way to concentrate the effluent from the biofilter. It is discussed relative to process technology and economics in Section 6. 


\section{SULFUR}

\subsection{OCCURRENCE AND EXTRACTION}

The primary deposits of sulfur in North America occur in the Gulf Coast region of the United States and Mexico. Most of these deposits occur in salt domes. It is believed that the free sulfur was formed by reduction of sulfate minerals by anaerobic bacteria [24].

The sulfur is usually extracted by pumping hot water into the deposits, melting the sulfur, and pumping the melted sulfur to the surface. This technique is called the Frasch process [25]. In addition to production of sulfur by extraction methods, sulfur is also recovered as a by-product from desulfurization processing of petroleum and natural gas. This source accounts for the largest portion of world sulfur production.

\subsection{USES OF SULFUR}

The main use of elemental sulfur is in the production of sulfuric acid, which, as discussed in Section 4, has a wide range of industrial uses. The largest use of sulfuric acid is in the manufacturing of phosphate fertilizer.

\subsection{SULFUR MARKET}

Over the last few years, the sulfur market has experienced price weakness related to sulfuric acid demand, in particular for fertilizer production. However, this decline is temporary, because developing countries are raising crop production by $3 \% / y r$ and most soils require fertilizer to sustain this growth rate. Rapidly increasing levels of food production in developing countries will boost global demand for sulfur-produced fertilizers from the current 14.7 million metric tons to 18.6 million metric tons by the turn of the century [25].

\subsection{SULFUR DISPOSAL}

Sulfur is considered a nonhazardous waste and may be disposed of in a special-waste landfill. A complete laboratory analysis must be performed in compliance with U.S. Environmental Protection Agency (EPA) requirements [26] to show that the sulfur waste does not contain other, more hazardous, components. To estimate the disposal cost of sulfur collected at Teepak, commercial- waste landfills were contacted and asked to provide estimates. On the basis of these estimates, the average disposal cost was calculated as shown in Appendix B and summarized in Table 2. 


\section{COST ESTIMATES FOR $\mathrm{CS}_{2}$ REMOVAL PROCESSES}

In Section 3, disposal costs for each of three different forms of sulfate and for elemental sulfur were estimated. In this section, estimates of plant investment and operating costs are discussed for several different combinations of biological $\mathrm{CS}_{2}$ removal and by-product production or treatment processes.

Aspen Plus, a well-known process simulator, has been applied to all processes, thereby developing process flow diagrams and plant designs; then process economic methods, coupled with Aspen Plus economic routines, have been used to estimate costs. The factored cost estimates developed have an absolute accuracy of only $\pm 30 \%$. However, since the same methods have been used for each process, it is believed that good relative accuracy was obtained and that the resulting cost ranking of processes is reliable. Of course, estimated costs are dependent on the assumptions and methods used. All details of the assumptions and results for each process are given below and in Appendix A.

In order to compare the cost estimates for the biological processes with a cost estimate for a standard nonbiological $\mathrm{CS}_{2}$ removal process, a carbon adsorption process has been simulated and costed by using methods exactly comparable to those used for the biological processes.

\subsection{CARBON ADSORPTION}

Carbon adsorption is a well-known process that has been extensively studied as a $\mathrm{CS}_{2}$ removal application [1]. Rather than using previously estimated costs for carbon adsorption, new costs were developed from Aspen Plus. The new costs are believed to provide a better basis for comparison - not because they are more accurate, but because the reference material, techniques, and assumptions used are similar to those used in the biological simulations.

In previous studies of $\mathrm{CS}_{2}$ removal by carbon adsorption, the best economics resulted by using an air feed that was only partially dried (to avoid extensive refrigerant dryer costs) and by desorbing with steam rather than with nitrogen [1]. This version is therefore the one presented here. Figure 4 shows the process flow diagram. Note that the line of adsorption towers shown in the figure is only representative, since 16 operating towers and four spares are required for the actual process.

The Teepak flow of contaminated air is split into four equal flows and each is sent to a large blower for boosting pressure to 5 psig. The air enters four refrigerant dryers that cool and remove moisture to about $50 \%$ relative humidity. The air is recombined in a single manifold and sent to the 


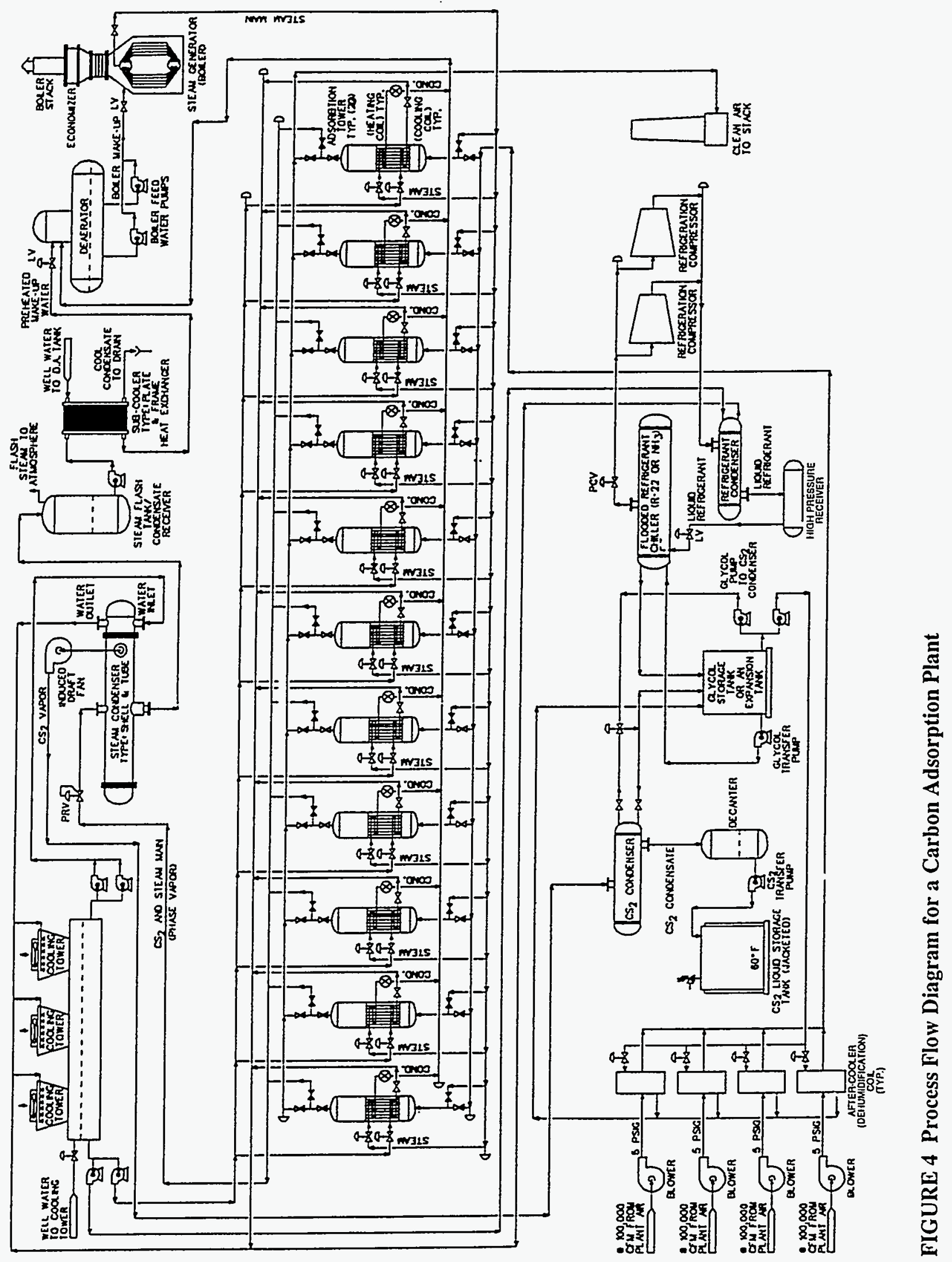


adsorption towers, which are housed in a prefabricated building. The air is split into 16 equal streams, each of which enters a single adsorption tower that has a carbon-bed depth of $5.4 \mathrm{ft}$. In the towers, $\mathrm{CS}_{2}$ and $\mathrm{H}_{2} \mathrm{~S}$ are removed, and the clean air is discharged to the atmosphere.

The breakthrough time is $16 \mathrm{~h}$; therefore, after a given adsorption tower has been operating for $16 \mathrm{~h}$, the $\mathrm{CS}_{2}$ concentration of the existing air will rise to $10 \mathrm{ppm}$, the breakpoint. The flow will then be directed to a freshly desorbed and cooled tower, and the previous tower will be desorbed. Each tower can be cooled with chilled water or heated with 150-psig steam by internal bed coils.

Desorption is accomplished by sealing the tower and flushing with $\mathrm{N}_{2}$, using steam coils to heat the bed to the desorption temperature (typically $300^{\circ} \mathrm{F}$ ), and then flooding the tower with $300^{\circ} \mathrm{F}$ steam, which will carry off the $\mathrm{CS}_{2}$. This preheating action prevents the desorption steam from exiting the tower with low $\mathrm{CS}_{2}$ concentration while the bed is being heated. Since excessive diluting of $\mathrm{CS}_{2}$ is prevented, this preheating step allows more efficient condensation and recovery of $\mathrm{CS}_{2}$. When desorption is completed, the hot bed must be cooled to less than $200^{\circ} \mathrm{F}$ before admitting air, to avoid the possibility of fire. The $\mathrm{CS}_{2}$ /steam mixture from the desorption flow is sent to a chilled-water condenser, where the steam is condensed. The resulting $\mathrm{CS}_{2} / \mathrm{H}_{2} \mathrm{O}$ vapor is further condensed in a refrigerant condenser, and the liquid $\mathrm{CS}_{2}$ is decanted and stored.

A summary of the results of the simulation is given in Table 4 . The table indicates that the total investment estimate is $\$ 31.6$ million, with $\$ 8.9$ million yearly operating costs, which includes a credit for the value of the recovered $\mathrm{CS}_{2}$ of almost $\$ 1$ million per year. Total equipment cost is about $\$ 5.6$ million. More details from the simulation are given in Appendix A.

\subsection{BIOFILTER}

Aspen Plus process and economic simulations have been developed for a biofilter plant that would purify the Teepak air emissions and produce 3\% sulfuric acid by-product. The assumptions used in preparing the biofilter plant simulation are given in Table 5.

The calculations used by Aspen Plus in completing the material balance for the biofilter are given in Appendix C. Details of the biofilter setup assumed for the simulations are given in Figures 5 and 6. A schematic process-flow diagram, showing the results of the mass balance, is given in Figure 7. A summary of the results from the Aspen Plus process and economic simulation is given in Table 6. The results indicate that the total investment is $\$ 7.8$ million, with $\$ 65.3$ million yearly operating costs. Total equipment cost is $\$ 1.4$ million. In this case, the $\mathrm{CS}_{2}$ is destroyed and worthless dilute sulfuric acid (3\%) is produced; thus, no by-product credit can be taken. The cost of disposal of the 3\% sulfuric acid (by methods outlined in Appendix B and Section 3) is more than $\$ 62$ million per year. The disposal cost represents $95.8 \%$ of total operating costs. 
A. Annual Operating Cost Summary

Production capacity for all products Base period

Plant availability

Raw material

Steam
$100.0 \%$

1996, Quarter I

$328 / 365.25$ days

$40,000 \mathrm{lb} / \mathrm{h}$ at $\$ 0.0028139 / \mathrm{lb}$

$\underline{\text { Annual Cost }(\$)}$

Raw material

Utilities

Labor (operators: two per shift, three shifts)

Operating $(16,000 \mathrm{~h})$

Maintenance

Supervision

Fringe benefits

Subtotal

Supplies

Operating

Maintenance

Subtotal

General works

General and administration

Property tax

Property insurance

Subtotal

Depreciation (15 years, straight line)

Gross operating cost

Less by-product credit

Net operating cost
Total

$\underline{\text { Annual Cost (\$) }}$

888,000

$1,574,000$

396,000

959,000

271,000

650,000

$2,276,000$

40,000

639,000

679,000

976,000

533,000

213,000

$1,722,000$

$1,776,000$

$\overline{8,915,000}$

993,000

$\overline{7,922,000}$

$5,090,000$

Fixed cost

$1,536,00$

Gross cost excluding depreciation

$7,139,000$

$8,915,000$

B. Process Unit Direct Cost Summary

Equipment cost

Total investment 
1. Contaminated Air

Flow

Moisture

Contamination

2. Biofilter Unit Cost

$\begin{array}{ll}\text { Units } & \text { Steel ISO containers, } 8 \mathrm{ft} \times 8 \mathrm{ft} \times 40 \mathrm{ft} \\ \text { Initial cost } & \$ 5,000 \\ \text { Modifications } & \$ 4,000 \\ \text { Total costs } & \$ 9,000\end{array}$

$400,000 \mathrm{ft}^{3} / \mathrm{min}\left(679,000 \mathrm{~m}^{3} / \mathrm{h}\right)^{\mathrm{a}}$

Saturated at $70^{\circ} \mathrm{F}$

$100 \mathrm{ppm} \mathrm{CS}_{2}, 80 \mathrm{ppm} \mathrm{H}_{2} \mathrm{~S}$

3. Superficial Velocity in Biofilter Bed

$12 \mathrm{ft} / \mathrm{min}$ (this value is an average of 13 existing biofilter systems from Ref. 27)

4. Overall Chemical Reaction in Biofilter

$$
5 \mathrm{CS}_{2}+4 \mathrm{H}_{2} \mathrm{~S}+10 \mathrm{H}_{2} \mathrm{O}+28 \mathrm{O}_{2} \rightarrow 14 \mathrm{H}_{2} \mathrm{SO}_{4}+5 \mathrm{CO}_{2}
$$

5. Total Number of Biofilter Units, $N$

From assumptions 1,2 , and $3, \mathrm{~N}=\left(400,00 \mathrm{ft}^{3} / \mathrm{min}\right) /[(12 \mathrm{ft} / \mathrm{min})(8 \mathrm{ft} \times 40 \mathrm{ft})]=104$

6. Configuration of Biofilter Field

Stacks of double units

Land area

7. Service Lines in Biofilter Field

Air feed

Solution feed

Acid recovery

8. Removal Efficiency of Biofilter
$\mathrm{CS}_{2}$
$100 \%$
$100 \%$

9. Solution Delivery Rate

Liquid-to-gas mass ratio

0.43

10. Acid Concentration in Solution

Acid-to-water mass ratio

11. Clean Air
Flow
Moisture
Contamination

52 (see Figures 5-6)

1 acre (see Figure 6 )

Horizontal ducting: $840 \mathrm{ft}$

Vertical ducting: $520 \mathrm{ft}$

Hastelloy pipe: $2,192 \mathrm{ft}$

Hastelloy pipe: $1,880 \mathrm{ft}$ 


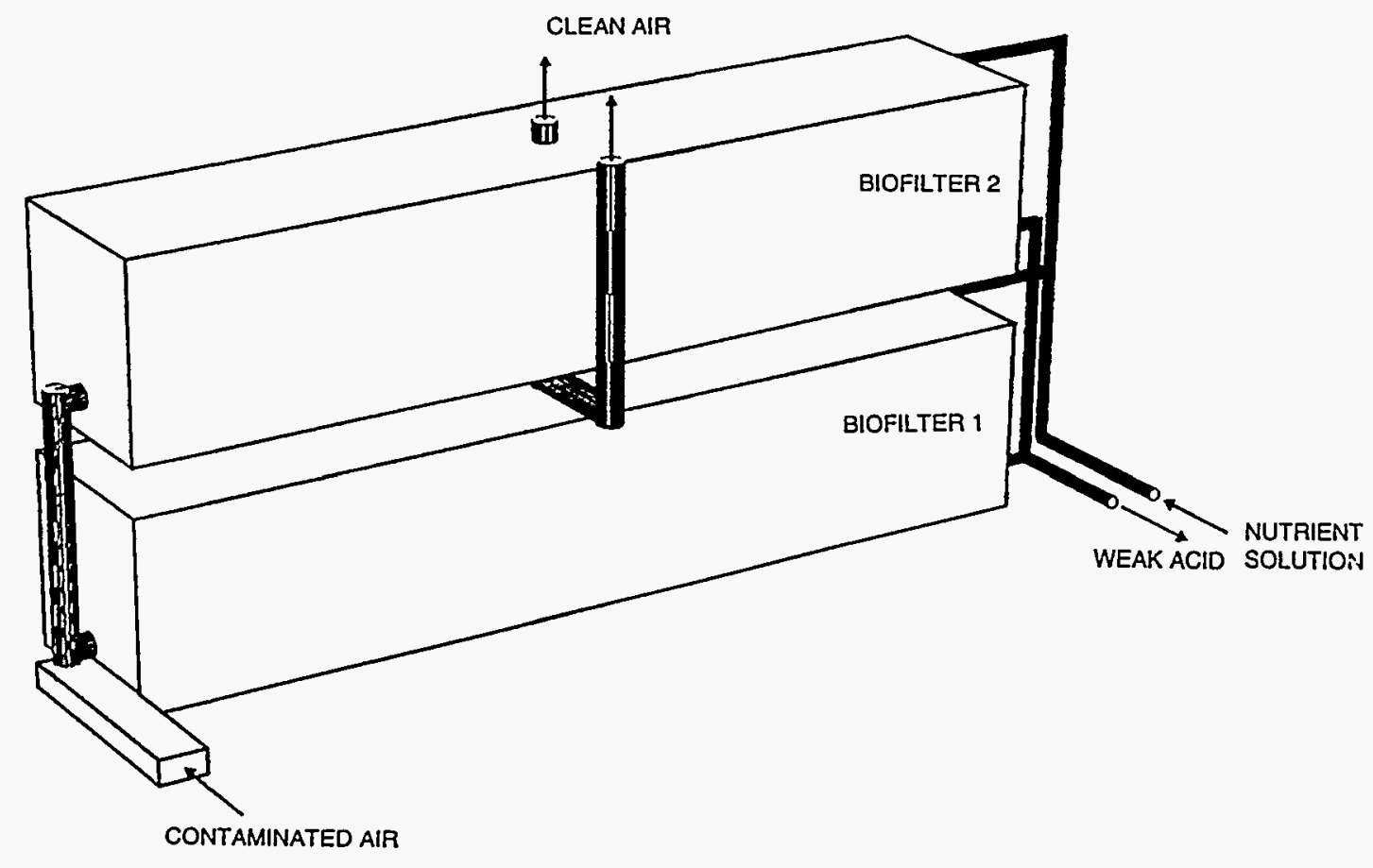

FIGURE 5 Configuration of One Double Unit of a Biofilter Field

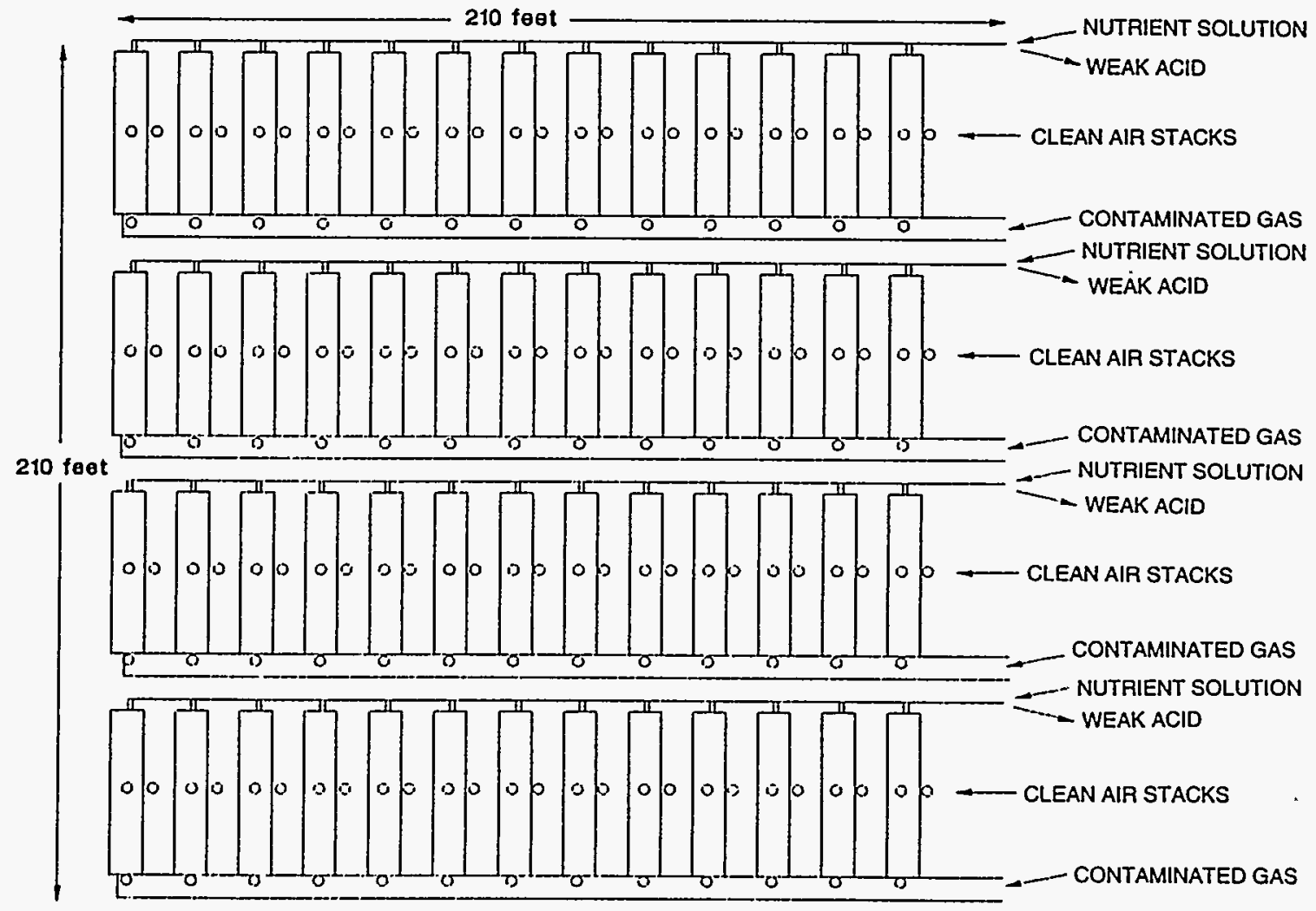

\section{FIGURE 6 Biofilter Field}




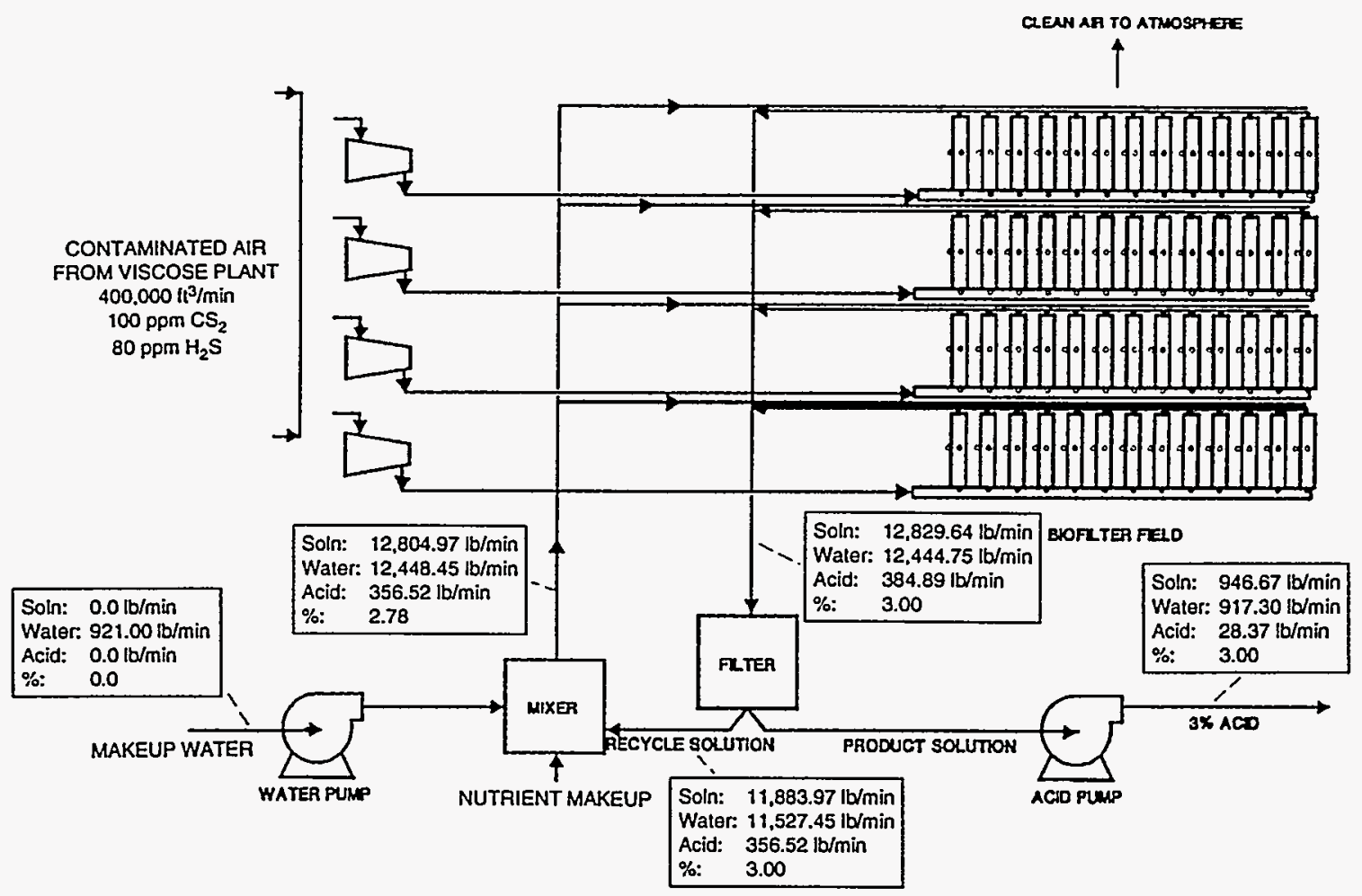

FIGURE 7 Process Flow Diagram for a Biofilter Plant

The disposal cost is that incurred if the $3 \%$ acid were treated and disposed of by a company specializing in such disposal; this cost is based on vendor quotes. Obviously, it is too large for serious consideration. It is given here simply for perspective. More details of the results from the Aspen Plus simulation are given in Appendixes $\mathrm{A}$ and $\mathrm{C}$.

\subsection{BIOFILTER WITH ACID CONCENTRATION}

As mentioned above, the product of biofiltration is dilute sulfuric acid, which has no market value but which carries a large disposal liability. Since concentrated sulfuric acid (95\%) is a valuable commodity, with a current market value of about $4 \phi / \mathrm{lb}$, the addition of an acid concentration plant to the biofilter was assumed to be an option worthy of study. Also, the viscose process under some assumptions could use $13 \%$ sulfuric acid to neutralize and precipitate the cellulose polymer in the final stage of the process. Therefore, another option we have chosen to study is acid concentration to $13 \%$ for the production of assumed recyclable $13 \%$ acid. $^{2}$ Based on the reasonable assumption

2 This option is only hypothetical, since the use of $13 \%$ acid directly would require additional evaporation capacity downstream of the viscose process. This additional capacity is not included in the $13 \%$ acid production cost estimates that follow. This option is given to emphasize the large effect of capacity on acid evaporation economics. 
TABLE 6 Summary of Simulation Results for a Biofilter Plant with 3\% Acid Waste

A. Annual Operating Cost Summary

Production capacity for all products

Base period

Plant availability

Raw material

$$
\mathrm{H}_{2} \mathrm{O}
$$

Raw material

Utilities

$$
130,000
$$

Waste treatment

Labor (operators: two per shift, three shifts)

$$
\begin{aligned}
& \text { Operating }(16,000 \mathrm{~h}) \\
& \text { Maintenance } \\
& \text { Supervision } \\
& \text { Fringe benefits } \\
& \text { Subtotal }
\end{aligned}
$$

Supplies

Operating

Maintenance Subtotal

General works

General and administration

Property tax

Property insurance

Subtotal

Depreciation (15 years, straight line)

Gross operating cost

Less by-product credit

Net operating cost

Summary

Fixed cost

Variable cost

Gross cost excluding depreciation Gross operating cost
$100.0 \%$

1995, Quarter III

$328 / 365.25$ days

$55,260 \mathrm{lb} / \mathrm{h}$ at $\$ 0.00014273 / \mathrm{lb}$

Annual Cost (\$)

Total

Annual Cost (\$)

62,000

$62,562,000$

385,000

274,000

132,000

316,000

$1,107,000$

38,000

183,000

221,000

474,000

152,000

61,000

688,000

508,000

$\overline{65,273,000}$

$\overline{65,278,000}$

$=$

$2,016,000$

$62,755,000$

B. Process Unit Direct Cost Summary

Equipment cost

Total investment
$1,357,900$

$7,768,000$ 
of $4 \phi / \mathrm{lb}$ for $95 \%$ acid, $13 \%$ acid is estimated to be worth $0.55 \phi / \mathrm{lb}$ to Teepak. This value is used in the estimates discussed below to calculate the hypothetical recycle credit to Teepak for $13 \%$ acid.

\subsubsection{Production of $13 \%$ Acid}

A schematic process flow diagram showing the combined biofiltration and acid concentration plant is given as Figure 8 . The biofiltration effluent acid is concentrated from $3 \%$ to $13 \% \mathrm{H}_{2} \mathrm{SO}_{4}$ in a single-stage concentrator. The reboiler, constructed of zirconium, is arranged in a natural circulation loop. The use of natural circulation eliminates the need for an expensive forcedcirculation pump in hot-acid service. The separator is constructed of fiberglass-reinforced plastic (FRP), and the overhead vapors are condensed in a $316 \mathrm{~L}$ stainless steel condenser. The system is maintained under vacuum by a jet-ejector/condenser system. The distillates flow from the condensers and ejectors to an FRP distillate tank and are then pumped to battery limits for disposal. The product is cooled in a carbon-block cooler and flows by gravity to battery limits for reuse. Table 7 lists the operating constants used in the simulation.

A summary of the results from the Aspen Plus process and economics simulation is given in Table 8. As shown, the total investment is $\$ 26.8$ million, which represents $\$ 19.1$ million for the evaporation plant and $\$ 7.7$ million for the biofilter plant. The annual gross operating costs are $\$ 6.1$ million for the evaporation plant and $\$ 1.9$ million for the biofilter plant. The total equipment cost is $\$ 4.7$ million, with $\$ 3.4$ million for the evaporation plant and $\$ 1.3$ million for the biofilter plant. By-product credit of $\$ 750,000$ per year for the $13 \%$ acid recycled to the viscose process produces a net operating cost of $\$ 7.3$ million.

\subsubsection{Production of $95 \%$ Acid}

For the case of production of $95 \%$ sulfuric acid, Figure 9 shows the combined biofiltration and acid concentration plant. The feed acid is concentrated from $3 \%$ to $95 \%$ in a three-stage concentrator. All three reboilers are arranged in natural circulation loops. The first-stage reboiler is constructed of zirconium; the second- and third-stage reboilers are constructed of tantalum. As for the $13 \%$-acid case, forced circulation pumps are not required in any of the stages. The first-stage separator is constructed from FRP, while the second- and third-stage separators are constructed from glass-lined steel. The acid overflows by gravity between stages. The overhead vapors from stages 1 and 2 are condensed in 316L stainless steel condensers.

The $95 \%$ solution has a relatively high vapor pressure of sulfuric acid, which requires that the vapors from stage 3 be condensed in a brick-lined, steel scrubber-condenser, with $75 \% \mathrm{H}_{2} \mathrm{SO}_{4}$ as the condensing liquid. A makeup stream from the stage 2 overflow is added to the scrubber-pump 


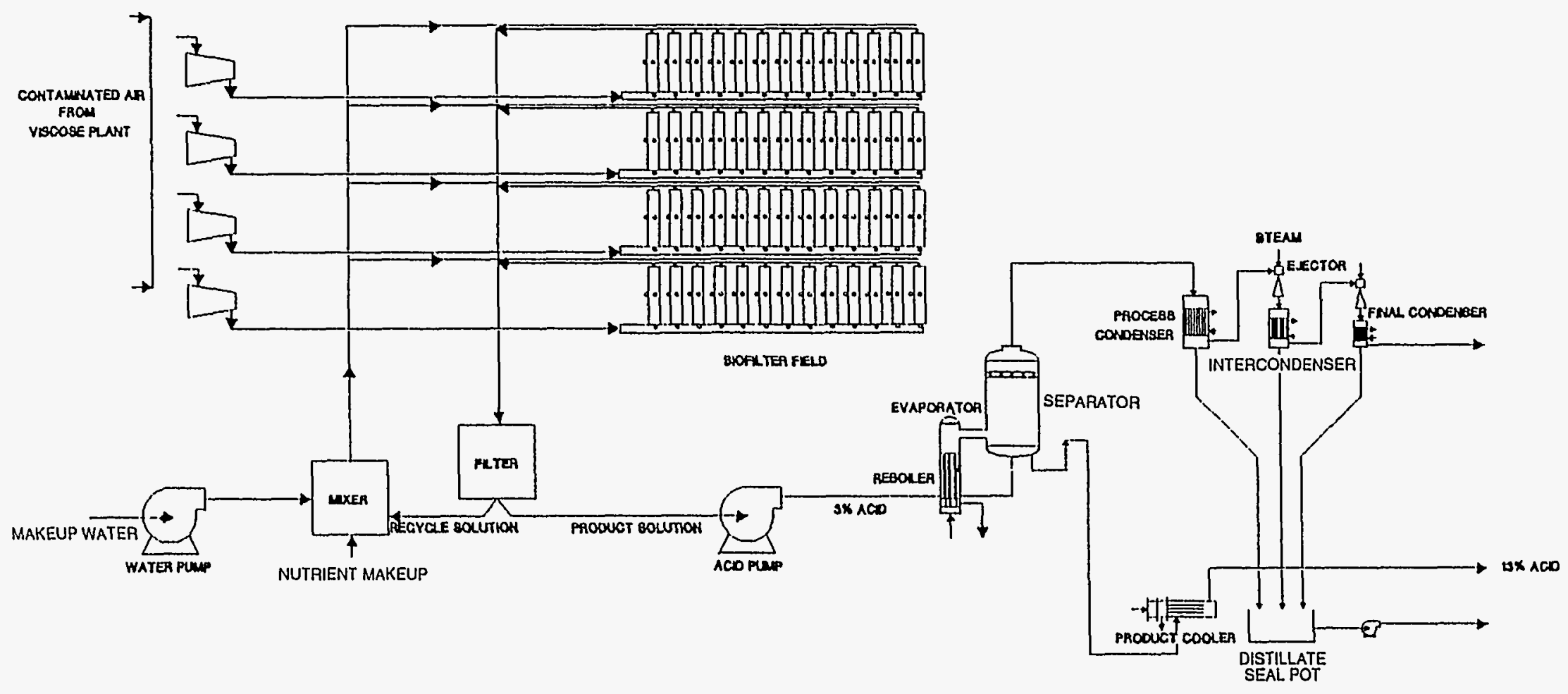

FIGURE 8 Biofiltration/Acid Concentration Plant for Producing 13\%Acid 
TABLE 7 Operating Constants for Acid Concentration

\section{Plants}

\begin{tabular}{|c|c|c|}
\hline $\begin{array}{l}\text { Operating } \\
\text { Constant }\end{array}$ & $\begin{array}{l}\text { Concentration } \\
\text { to } 13 \%\end{array}$ & $\begin{array}{c}\text { Concentration } \\
\text { to } 95 \%\end{array}$ \\
\hline \multicolumn{3}{|l|}{ Feed Acid } \\
\hline Flow & $53,200 \mathrm{lb} / \mathrm{h}$ & $53,200 \mathrm{lb} / \mathrm{h}$ \\
\hline Concentration & $3 \% \mathrm{H}_{2} \mathrm{SO}_{4}$ & $3 \% \mathrm{H}_{2} \mathrm{SO}_{4}$ \\
\hline Temperature & $75^{\circ} \mathrm{F}$ & $75^{\circ} \mathrm{F}^{2}$ \\
\hline \multicolumn{3}{|l|}{ Product Acid } \\
\hline Flow & $12,277 \mathrm{lb} / \mathrm{h}$ & $1,407 \mathrm{lb} / \mathrm{h}$ \\
\hline Concentration & $13 \% \mathrm{H}_{2} \mathrm{SO} 4$ & $95 \% \mathrm{H}_{2} \mathrm{SO}_{4}$ \\
\hline Temperature & $120^{\circ} \mathrm{F}^{2}$ & $200^{\circ} \mathrm{F}^{2}$ \\
\hline \multicolumn{3}{|l|}{ Distillate } \\
\hline Flow & $40,923 \mathrm{lb} / \mathrm{h}$ & $51,656 \mathrm{lb} / \mathrm{h}$ \\
\hline Concentration & $<100 \mathrm{ppm}$ & $0.25 \% \mathrm{H}_{2} \mathrm{SO}_{4}$ \\
\hline Temperature & $120^{\circ} \mathrm{F}$ & $120^{\circ} \mathrm{F}$ \\
\hline \multicolumn{3}{|l|}{ Steam } \\
\hline Consumption & $53,000 \mathrm{lb} / \mathrm{h}$ & $51,656 \mathrm{lb} / \mathrm{h}$ \\
\hline Pressure & 100 psig & 250 psig \\
\hline \multicolumn{3}{|l|}{ Cooling Water } \\
\hline Flow & 5,500 usgpm $^{\mathrm{a}}$ & 7,900 usgpm \\
\hline Supply temperature & $86^{\circ} \mathrm{F}$ & $86^{\circ} \mathrm{F}$ \\
\hline Return temperature & $104^{\circ} \mathrm{F}$ & $104^{\circ} \mathrm{F}$ \\
\hline Electrical Power (pumps only) & $10 \mathrm{hp}$ & $20 \mathrm{hp}$ \\
\hline
\end{tabular}

a usgpm $=$ U.S. gallons per minute.

tank, and a bleed stream from the scrubber circulation loop joins the feed to stage 1 . The scrubber-condenser acid is cooled in a carbon-block cooler. All stages are maintained under a vacuum by jet-ejector/condenser vacuum systems. The distillates flow from the condensers and ejectors to an FRP distillate tank and are pumped to battery limits for disposal. The product is cooled in a carbon- block cooler and flows by gravity to battery limits for recovery. The operating constants used in the simulation for this case are listed in Table 7.

About $8 \%$ of the acid value in the feed is lost with the distillate. This loss occurs because the partial pressure of the acid vapor becomes significant at strengths over $70 \%$, resulting in a loss of acid from the overhead vapors of stage 2 . The vapors from stage 3 are condensed by scrubbing with acid to avoid a much more significant loss of acid. 
TABLE 8 Summary of Simulation Results for a Biofilter Plant with Acid Concentration to 13\%

A. Annual Operating Cost Summary

Production capacity for all products

Base period

Plant availability

Raw material

$$
\mathrm{H}_{2} \mathrm{O}
$$

$100.0 \%$

1996, Quarter II

$328 / 365.25$ days

$55,260 \mathrm{lb} / \mathrm{h}$ at $\$ 0.00014848 / \mathrm{lb}$

$\underline{\text { Annual Cost (\$) }}$

Total

Annual Cost (\$)

Raw material

65,000

Utilities

$$
1,559,000
$$

Labor (operators: two per shift, three shifts)

$\begin{array}{ll}\text { Operating }(16,000 \mathrm{~h}) & 400,000 \\ \text { Maintenance } & 949,000 \\ \text { Supervision } & 270,000 \\ \text { Fringe benefits } & 647,000\end{array}$

Subtotal

$2,266,000$

Supplies

Operating

Maintenance

Subtotal

40,000

632,000

672,000

General works

General and administration $\quad 971,000$

Property tax

527,000

Property insurance

211,000

Subtotal

Depreciation (15 years, straight line)

Gross operating cost

Less by-product credit

Net operating cost

$1,709,000$

$1,757,000$

$8,028,000$

749,000

$7,279,000$

Summary

Fixed cost

Variable cost

Gross cost excluding depreciation Gross operating cost

B. Process Unit Direct Cost Summary 


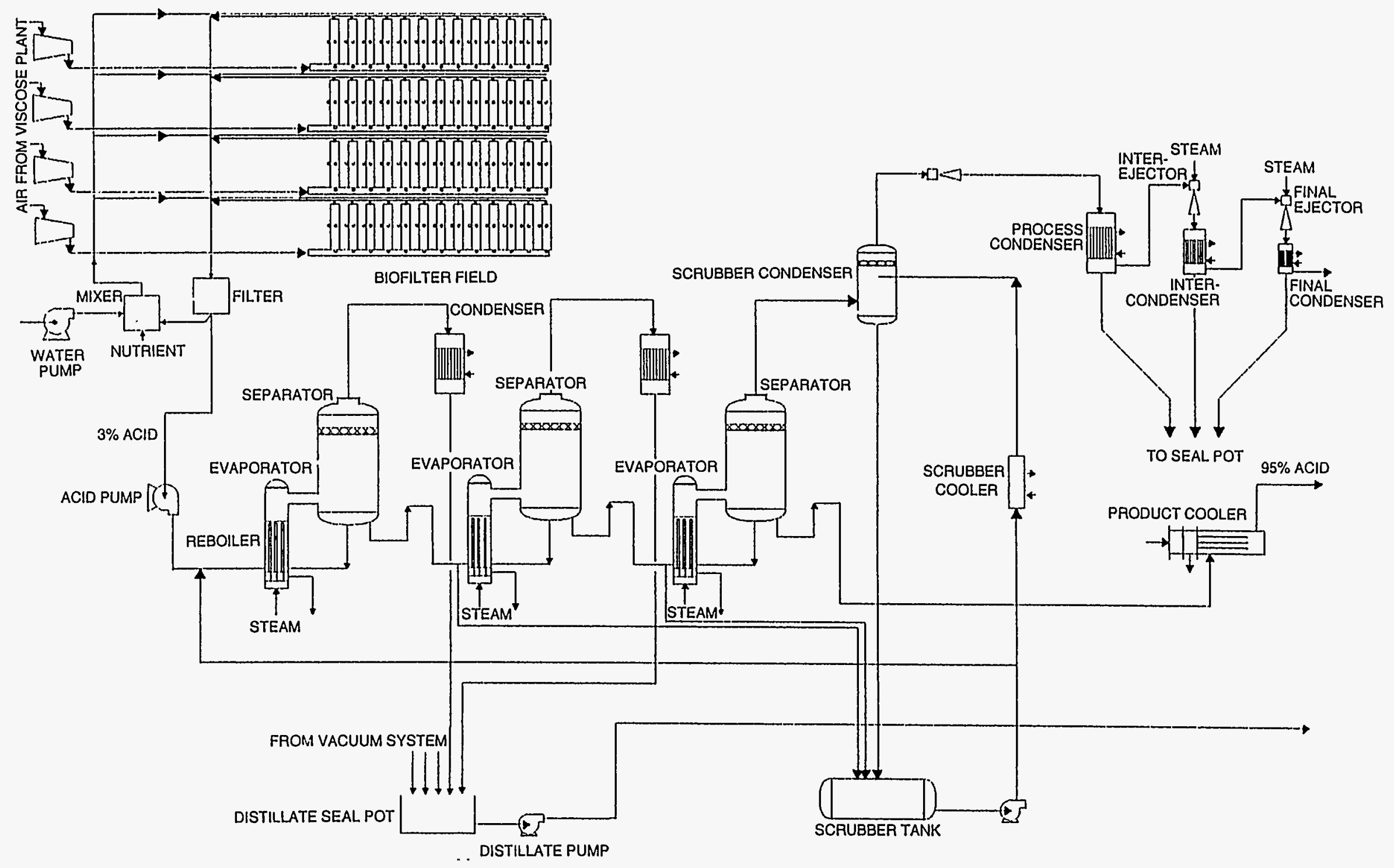

FIGURE 9 Biofiltration/Acid Concentration Plant for Producing 95\% Acid 
The steam consumption increases from less than $1.3 \mathrm{lb}$ steam/lb distillate for the $13 \%$ case to more than $1.4 \mathrm{lb} / \mathrm{lb}$ for the $95 \%$ case. At the same time, the steam supply pressure must be greater for the $95 \%$ case than for the $13 \%$ case because of the higher boiling point of concentrated acid.

Note that the evaporation economics are much more favorable for the $13 \%$ case. There is a breakpoint in the cost of evaporation near the region of $60-65 \% \mathrm{H}_{2} \mathrm{SO}_{4}$ beyond which capital and operating costs increase significantly. This breakpoint is due to the need to switch from zirconium to tantalum construction and also because of the increased boiling point and increased partial pressure of acid at higher concentrations.

A summary of the simulation results is given in Table 9. The total investment is $\$ 48.9$ million, with components of $\$ 41.2$ million and $\$ 7.7$ million for the evaporation and biofilter plants, respectively. The annual gross operating costs are $\$ 10.8$ million and $\$ 2.0$ million, respectively, and the total equipment costs are $\$ 7.3$ million and $\$ 1.3$ million. By-product credit for the $95 \%$ acid product of $\$ 0.73$ million produces a net operating cost of $\$ 12.2$ million per year.

\subsection{NEUTRALIZATION WITH LIMESTONE}

Because limestone can neutralize sulfuric acid and also is a relatively inexpensive material, neutralization of the biofilter effluent with purchased limestone was considered. Two possibilities exist. The solid gypsum product of the acid-limestone reaction could be produced as a marketable commodity or the gypsum product could be landfilled. If the gypsum is to be of marketable grade, care must be taken to ensure its continuing quality. Existing plants for producing marketable gypsum use $65 \%$ sulfuric acid and a "den" reactor and other devices to ensure complete reaction. To duplicate this process at Teepak, acid concentration to $65 \%$ must be incorporated.

If the $3 \%$ acid is simply to be neutralized with limestone and the result landfilled, there is no need to ensure solid product quality. The main goal is to achieve total acid neutralization; therefore, this process has no need to concentrate the acid. Since limestone is benign in landfill, some excess limestone can be used to assure total acid neutralization.

\subsubsection{Production of Marketable Gypsum}

Calcium sulfate, or gypsum, is a commodity with a variety of uses (e.g., as a component of cements, plaster, paint, etc.). It occurs naturally in the earth and can be mined, so it has a relatively low market value. It can also be manufactured from $65 \%$ sulfuric acid and limestone. Therefore, another option for weak sulfuric acid disposal is to construct, along with the biofilter plant, both an evaporative acid concentration plant and a gypsum plant. Thus, the $3 \%$ acid from the biofilter is sent 
TABLE 9 Summary of Simulation Results for a Biofilter Plant with Acid Concentration to $95 \%$

A. Annual Operating Cost Summary

Production capacity for all products
Base period
Plant availability
Raw material
$\mathrm{H}_{2} \mathrm{O}$

Raw material
Utilities
Labor (operators: two per shift, three shifts)
Operating (16,000 $\mathrm{h}$ )
Maintenance
Supervision
Fringe benefits
Subtotal

Supplies

Operating

Maintenance

Subtotal

General works

General and administration

Property tax

Property insurance

Subtotal

Depreciation (15 years, straight line)

Gross operating cost

Less by-product credit

Net operating cost

Summary

Fixed cost

Variable cost

Gross cost excluding depreciation

Gross operating cost

B. Process Unit Direct Cost Summary

Equipment cost

Total investment
100.0\%
1996, Quarter III
$328 / 365.25$ days

$55,260 \mathrm{lb} / \mathrm{h}$ at $\$ 0.00015272 / \mathrm{lb}$

$\underline{\text { Annual Cost }(\$)}$

Total

Annual Cost (\$)

67,000

$1,966,000$

412,000

$1,726,000$

428,000

$1,026,000$

$3,592,000$

41,000

$1,151,000$

$1,192,000$

$1,539,000$

959,000

384,000

$2,882,000$

$3,197,000$

$\overline{12,895,000}$

730,000

$\overline{12,165,000}$

$7,666,000$

$2,032,000$

Totalinvestment 
to the concentration plant, and the $65 \%$ acid from the concentrator is sent to the gypsum plant, where it is reacted with limestone to produce gypsum.

In Figure 10, only the gypsum plant is shown, since the biofilter and acid concentration plants are shown in previous figures. Limestone is delivered to the plant by truck. It is conveyed by belt to a crusher/grinder, where it is ground to a powder. The powder, transportable by entrainment in air, is sent to a cyclone and then to a mixer/reactor, where it is mixed with $65 \%$ sulfuric acid to produce gypsum. To ensure complete reaction, the mixer contents discharge into a holding chamber, or den, where they remain for a variable residence time of between 10 and 40 min. The gypsum product is removed, cut, and stored. The product cures in storage for at least two days.

A summary of the economic simulation of the composite biofilter, acid concentrator, and gypsum plant is given in Table 10. The total investment is $\$ 40.4$ million. The annual net operating costs are $\$ 11.7$ million, which includes a small by-product credit ( $\$ 0.083$ million) for the gypsum produced. The total equipment costs are $\$ 7.1$ million. Additional economic data from the simulation are given in Appendix A.

\subsubsection{Production of Waste Gypsum}

Figure 11 shows the process flow diagram envisioned for production of 3\% sulfuric acid by biofilter, neutralization by powdered limestone, and landfilling of the solid product. The biofilter field, as in previously described processes, produces $3 \%$ sulfuric acid solution, which is pumped to a stirred mixer. Powdered limestone is delivered to the plant by truck and is fed into the mixer. The water/limestone slurry is separated by decantation, and the waste gypsum is sent to landfill by truck.

A summary of the economic simulation of the composite biofiltration/neutralization is given in Table 11. The total investment is $\$ 8.7$ million. The annual net operating costs are $\$ 3.6$ million. The total equipment costs are $\$ 1.5$ million. Additional economic data from the simulation are given in Appendix A.

\subsection{PRODUCTION OF ELEMENTAL SULFUR}

As discussed in Section 5, elemental sulfur is an inexpensive material to landfill since it is environmentally benign. It also is a valuable feedstock used in manufacturing sulfuric acid, paper, rubber, and many other well-known products. Therefore, a possible approach for a $\mathrm{CS}_{2}$-removal process may be to control and limit the biological oxidation of $\mathrm{CS}_{2}$ and $\mathrm{H}_{2} \mathrm{~S}$ in a biocolumn, as discussed in Section 2, to produce a mixture of sulfides and elemental sulfur. It is assumed that, under controlled $\mathrm{pH}$, the product will be mostly elemental sulfur. This assumption is a conservative 


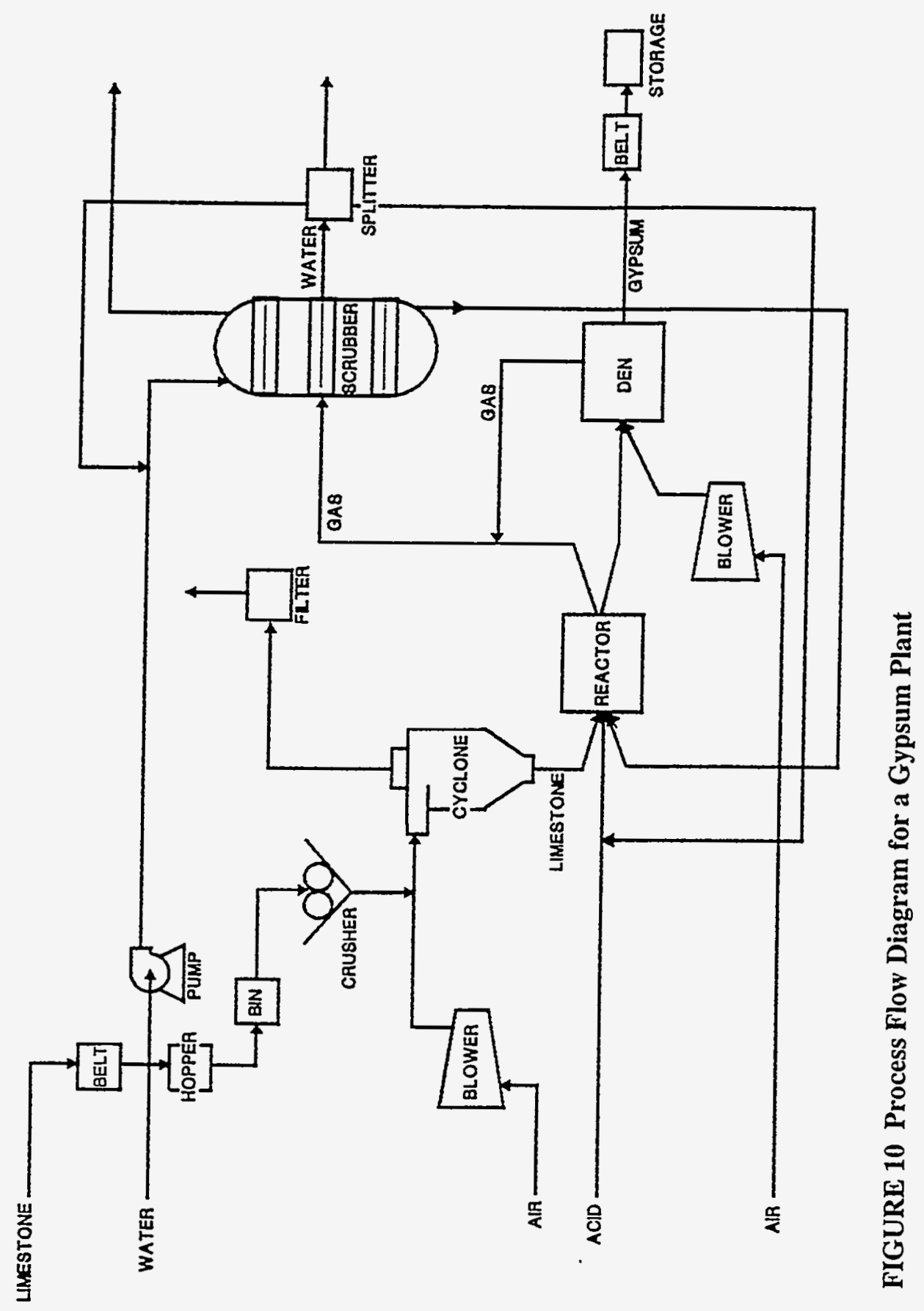


TABLE 10 Summary of Simulation Results for a Biofilter Plant with Acid Concentration to $65 \%$ for Gypsum Production

A. Annual Operating Cost Summary

Production capacity for all products

Base period

Plant availability

Raw material

$\mathrm{H}_{2} \mathrm{O}$ (feedstock)

Lime (for scrubber)

Water (for cooling)

Raw material

$$
\begin{aligned}
& \mathrm{H}_{2} \mathrm{O} \\
& \text { Lime } \\
& \text { Water } \\
& \quad \text { Subtotal }
\end{aligned}
$$

Utilities

Labor (operators: two per shift, three shifts)

$$
\begin{aligned}
& \text { Operating (16,000 h) } \\
& \text { Maintenance } \\
& \text { Supervision } \\
& \text { Fringe benefits }
\end{aligned}
$$
Subtotal

Supplies

Operating

Maintenance

Subtotal

General works

General and administration

Property tax

Property insurance Subtotal

Depreciation (15 years, straight line)

Gross operating cost

Less by-product credit

Net operating cost

Summary

Fixed cost

Variable cost

Gross cost excluding depreciation

Gross operating cost
$100.0 \%$

1996, Quarter II

$328 / 365.25$ days

$54,055 \mathrm{lb} / \mathrm{h}$ at $\$ 0.00015016 / \mathrm{lb}$

$2,187.4265 \mathrm{lb} / \mathrm{h}$ at $\$ 0.032208 / \mathrm{lb}$

$7,118.3502 \mathrm{lb} / \mathrm{h}$ at $\$ 0.00015016 / \mathrm{lb}$

Annual Cost (\$)

Total

Annual Cost (\$)

64,000

556,000

8,000

628,000

$1,899,000$

405,000

$1,428,000$

367,000

880,000

$3,079,000$

40,000

952,000

992,000

$1,320,000$

793,000

317,000

$2,430,000$

$2,644,000$

$\overline{11,673,000}$

83,000

$\overline{11,590,000}$

$6,501,000$

$2,528,000$

$9,029,000$

$11,673,000$

B. Process Unit Direct Cost Summary

Equipment cost 


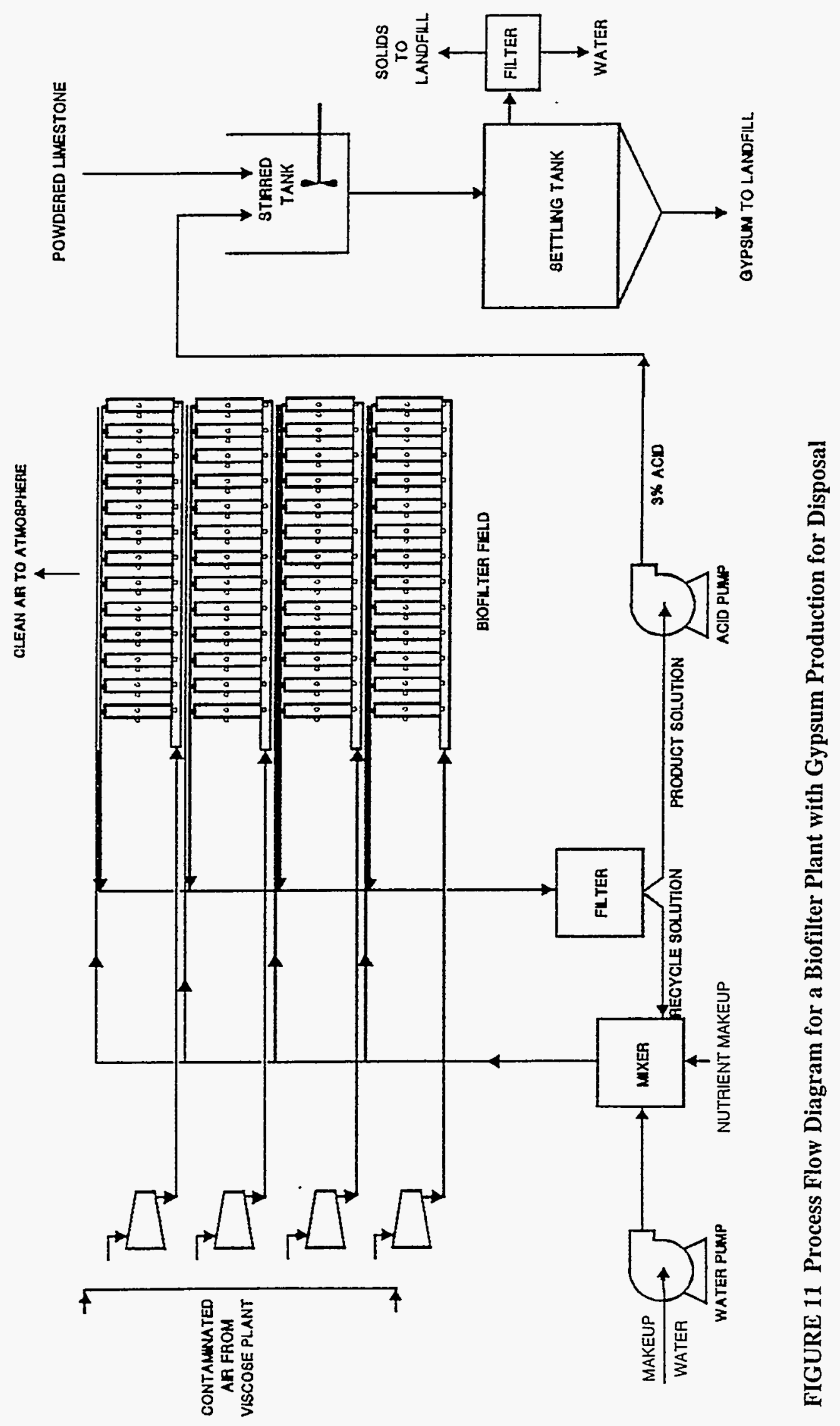


TABLE 11 Summary of Simulation Results for a Biofilter Plant with $3 \% \mathrm{H}_{2} \mathrm{SO}_{4}$ Neutralized by Limestone

A. Annual Operating Cost Summary

Production capacity for all products

Base period

Plant availability

Raw material

$\mathrm{H}_{2} \mathrm{O}$

$\mathrm{CaCO}_{3}$ (for neutralization of acid)

Raw material

$$
\begin{aligned}
& \mathrm{H}_{2} \mathrm{O} \\
& \mathrm{Ca} \mathrm{CO}_{3} \\
& \quad \text { Subtotal }
\end{aligned}
$$

Utilities

Waste treatment

Labor (operators: two per shift, three shifts)

$\begin{array}{ll}\text { Operating }(16,000 \mathrm{~h}) & 385,000 \\ \text { Maintenance } & 307,000 \\ \text { Supervision } & 138,000 \\ \text { Fringe benefits } & 332,000\end{array}$

325,000

(85,000

38,000

332,000
$100.0 \%$
1995, Quarter III
$328 / 365.25$ days

$55,260 \mathrm{lb} / \mathrm{h}$ at $\$ 0.00014273 / \mathrm{lb}$

$1,738.0000 \mathrm{lb} / \mathrm{h}$ at $\$ 0.023686 / \mathrm{lb}$

Annual Cost (\$)

Total

Annual Cost (\$)

62,000

387,000

130,000

205,039

38,000

205,000

243,000

498,000

170,000

68,000

737,000

568,000

$\overline{3,558,000}$

Gross operating cost

Less by-product credit

Net operating cost

Summary

Fixed cost

Variable cost

Gross cost excluding depreciation

Gross operating cost

848,000

$2,990,000$

$3,558,000$

B. Process Unit Direct Cost Summary

Equipment cost 
one, since a process that produces less sulfur and more sulfate will have higher costs. If the current process with high assumed sulfur yields is not competitive, the process with lower yields will also be noncompetitive.

In the biocolumn, colloidal elemental sulfur is excreted by the bacteria cells and can be removed from the biolayer by a flowing liquid solution, provided the bacteria are immobilized. The bacteria will attach to the plastic surfaces of the packing; therefore, a vertical, cylindrical column containing plastic rings, saddles, or other common packings can be used. This idea has been studied and patented by Torres-Cardona et al. [7] and also studied by Cork [8]. Figure 12 shows the process flow diagram envisioned for this process.

Each of the 14 towers contains plastic-ring packing with biolayer attached (see Figure 2). The contaminated air is split into 14 components, each of which enters at the bottom of a tower. The air is cleaned by biolayer extraction of $\mathrm{CS}_{2}$ and $\mathrm{H}_{2} \mathrm{~S}$, and the clean air exits to the atmosphere at the tower tops. A solution of controlled $\mathrm{pH}$ enters the top of each tower and flows downward countercurrent to the air flow. The solution carries the sulfur particles out of the towers and into a clarifier, where the sulfur settles and is removed as product. The clarified solution is pumped to a mixing tank, where makeup water is added. A controlled amount of caustic is also added in order to maintain the $\mathrm{pH}$ of the recycle solution. Bacterial nutrients, consisting of the compounds $\mathrm{NH}_{4} \mathrm{Cl}$, $\mathrm{K}_{2} \mathrm{HPO}_{4}, \mathrm{MgCl}_{2}$, and $\mathrm{NaCl}$, are also made up in the mixing tank.

On the basis of pilot-plant results $[7,8]$, a representative, superficial gas velocity in the absorption tower of $66 \mathrm{ft} / \mathrm{min}$ is optimum. Thus, the flow area required for 400,000 cubic feet per minute (CFM) is $6,063 \mathrm{ft}^{2}$, which can be accommodated by 14 towers of $24-\mathrm{ft}$ diameter. Other parameters assumed on the basis of the pilot-plant results are

$\begin{array}{ll}\text { Liquid-to-air mass ratio } & 3 \text { to } 7 \\ \text { Gas temperature } & 25^{\circ} \mathrm{C} \\ \text { Conversion of sulfur to elemental sulfur } & 97 \% \\ \text { pH of recycle solution } & 7 \text { to } 8 .\end{array}$

A summary of the results from the Aspen Plus process and economic simulations is given in Table 12. The table indicates that the total investment is $\$ 29.4$ million, with $\$ 7.5$ million yearly operating costs. The total equipment cost is $\$ 5.2$ million. Note that a by-product credit of $\$ 0.047$ million per year is taken for the elemental sulfur produced. The disposal cost of the small quantity of sulfates produced was not estimated or accounted for. More details of the results from the Aspen Plus simulation are given in Appendix A. 


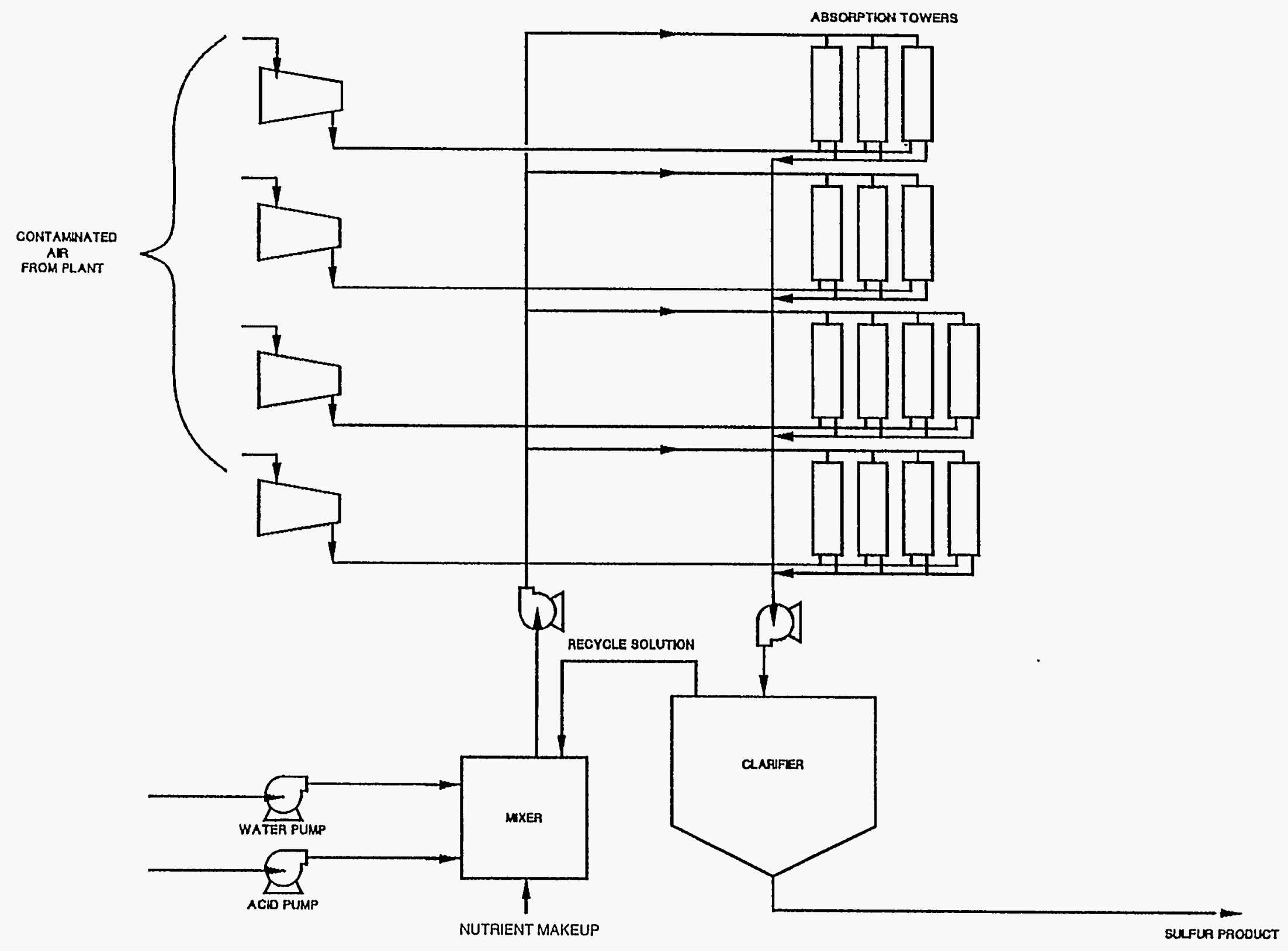

FIGURE 12 Process Flow Diagram for a Biocolumn Plant 
TABLE 12 Summary of Simulation Results for a Biocolumn Producing Elemental Sulfur

A. Annual Operating Cost Summary

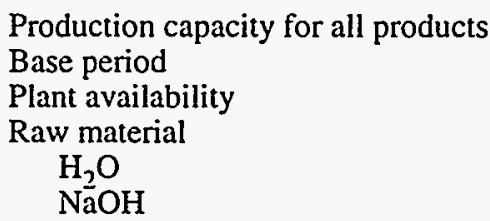

$$
\begin{aligned}
& \mathrm{H}_{2} \mathrm{O} \\
& \text { Lime } \\
& \quad \text { Subtotal }
\end{aligned}
$$

Utilities

Labor (operators: two per shift, three shifts)

Operating $(16,000 \mathrm{~h})$

Maintenance

Supervision

Fringe benefits Subtotal

Supplies

Operating

Maintenance Subtotal

General works

General and administration

Property tax

Property insurance

Subtotal

Depreciation (15 years, straight line)

Gross operating cost

Less by-product credit

Net operating cost

Summary

Fixed cost

Variable cost

Gross cost excluding depreciation Gross operating cost

B. Process Unit Direct Cost Summary
$100.0 \%$

1996, Quarter I

$328 / 365.25$ days

$19,651 \mathrm{lb} / \mathrm{h}$ at $\$ 0.00014681 / \mathrm{lb}$

$1,657.1920 \mathrm{lb} / \mathrm{h}$ at $\$ 0.088867 / \mathrm{lb}$

Annual Cost (\$)

Total

Annual Cost (\$)

23,000

$1,162,000$

$1,185,000$

162,000

396,000

901,000

259,000

622,000

$2,178,000$

40,000

601,000

640,000

934,000

500,000

200,000

$1,634,000$

$1,668,000$

$\overline{7,467,000}$

47,000

$\overline{7,421,000}$

$4,453,000$

$1,346,000$

$5,799,000$

$7,467,000$ 


\subsection{SUMMARY}

Table 13 shows a summary of the costs of each of the $\mathrm{CS}_{2}$ removal processes discussed above. These cost estimates are based on rough designs determined from pilot-plant and bench-scale testing, coupled with necessary assumptions, some of which are arbitrary (see Sections 6.1-6.5). Because of this rough basis and also because the method used includes factored cost estimates, the simulation results cannot be considered more than $\pm 30 \%$ accurate. More accurate estimates are not possible without more complete designs that will allow vendor quotes and detailed costing, which is beyond the scope of this study. Although the conclusions developed from Table 13 must be considered tentative, they do provide useful comparative trends in costs. The relative accuracy is more reliable than the absolute accuracy, since all estimates were derived by using similar methods. On the basis of Table 13, the following observations can be made:

- The biofilter plant with limestone neutralization and gypsum disposal is by far the least costly process, with investment and operating costs both low. Further study of this option, with more accurate equipment and operating estimates and projection of landfill costs into the future, is needed.

- Of the seven process options, the biofilter plant producing $3 \%$ acid is the least costly to purchase because of relatively modest equipment needs. However, it is the most expensive to operate because of the high disposal costs of $3 \%$ acid.

- Acid-disposal costs can be eliminated by including an acid-concentrating train with the biofilter plant. Both operating and capital costs of such composite plants are proportional to the extent of acid concentration.

- The biofilter plant with a $13 \%$ acid concentration is the least costly biofilter/acidconcentration option, due to the relatively low amount of evaporation required to concentrate the acid from $3 \%$ to $13 \%$. However, additional evaporation equipment would be needed in the viscose plant if this option were chosen. These additional costs have not been estimated.

- The investment and operating cost of the carbon adsorption process is estimated to be higher than either the biocolumn or the biofilter plant with $13 \%$ acid concentration. However, the magnitudes of the differences in cost among these three processes may not remain the same if more accurate estimates were available. A more detailed cost study to distinguish among cases 1,3 , and 7 is needed for further comparison. 
TABLE 13 Summary of Costs for $\mathrm{CS}_{2}$ Removal Processes

\begin{tabular}{|c|c|c|c|c|c|c|}
\hline \multirow[b]{2}{*}{ Case } & \multirow[b]{2}{*}{ Process } & \multirow{2}{*}{$\begin{array}{c}\text { Total } \\
\text { Investment } \\
\text { (\$ million) }\end{array}$} & \multicolumn{2}{|c|}{ Operating Costs ( $\$$ million/yr) } & \multirow{2}{*}{$\begin{array}{c}\text { Equipment } \\
\text { Costs } \\
(\$ \text { million }) \\
\end{array}$} & \multirow{2}{*}{$\begin{array}{c}\text { By-Product } \\
\text { Credit } \\
(\$ \text { million/yr) }\end{array}$} \\
\hline & & & Total & Utilities & & \\
\hline 1 & $\begin{array}{l}\text { Carbon } \\
\text { adsorption }\end{array}$ & 31.6 & 8.9 & 1.6 & 5.6 & 0.99 \\
\hline 2 & $\begin{array}{l}\text { Biofilter, } \\
\text { vendor disposal }\end{array}$ & 7.8 & 65.3 & 0.13 & 1.4 & 0.00 \\
\hline 3 & $\begin{array}{l}\text { Biofilter, } \\
13 \% \text { acid }\end{array}$ & 26.9 & 7.3 & 1.56 & 4.7 & 0.75 \\
\hline 4 & $\begin{array}{l}\text { Biofilter, } \\
95 \% \text { acid }\end{array}$ & 48.9 & 12.9 & 1.97 & 8.6 & 0.73 \\
\hline 5 & $\begin{array}{l}\text { Biofilter, } \\
65 \% \text { acid, } \\
\text { gypsum sold }\end{array}$ & 40.4 & 11.6 & 1.90 & 7.1 & 0.08 \\
\hline 6 & $\begin{array}{l}\text { Biofilter, } \\
\text { gypsum disposal }\end{array}$ & 8.7 & 3.6 & 0.13 & 1.5 & 0.00 \\
\hline 7 & Biocolumn & 29.4 & 7.5 & 0.16 & 5.2 & 0.05 \\
\hline
\end{tabular}




\section{CONCLUSIONS}

Biological removal of sulfides from air has been demonstrated and proven by others for application at much lower air flows than the flow at Teepak. Therefore, biofiltration, the use of a porous layer of biologically active material as a removal medium, possibly can remove the $\mathrm{CS}_{2}$ and $\mathrm{H}_{2} \mathrm{~S}$ from the Teepak air and produce a 3\% sulfuric acid product. However, on the basis of existing knowledge of the rates of biological removal of $\mathrm{CS}_{2}$ and $\mathrm{H}_{2} \mathrm{~S}$ and of allowable superficial velocities, the bed cross-sectional area will have to be very large; such a bed will require more than 100 container-sized reactors, which, double-stacked, will take up about one acre of land. The plant will require an investment on the order of $\$ 8$ million.

Biofiltration at Teepak will produce over 200,000 tons of $3 \%$ acid per year. Such dilute acid is not a marketable commodity, nor is it disposable at any reasonable cost. The options under biofiltration are thus to convert the weak acid either to some recyclable or marketable commodity or to some form that is economically disposable. The possible ways of producing a marketable product by means of biofiltration at Teepak all require acid concentration, which can only be done by expensive evaporative plants. Production of commodity-grade $95 \%$ sulfuric acid by biofiltration at Teepak requires building the biofilter plant plus a large, three-stage evaporator plant, with a total investment on the order of $\$ 49$ million.

Options for producing the marketable or recyclable commodities - $13 \%$ acid, gypsum, or elemental sulfur - are roughly comparable in terms of investment, falling in the range between $\$ 27$ and $\$ 40$ million. (This range also includes the investment required for a carbon adsorption plant). The Teepak plant can use 13\% sulfuric acid. Production of $13 \%$ sulfuric acid from biofiltration for recycling at Teepak requires building the biofilter plant plus a single-stage evaporator plant, with a total investment on the order of $\$ 27$ million. However, additional costs for water evaporation from the viscose plant recycle solution are implied in this case. These costs have not been estimated in this study, but they are likely to be substantial, thus eliminating this option as a candidate for implementation. Production of commodity-grade gypsum from biofiltration at Teepak requires building the biofilter plant, a three-stage evaporator plant, and a gypsum plant, with a total investment on the order of $\$ 40$ million. Production of elemental sulfur by bacterial action in a packed column may be possible. This option would require construction of a biocolumn plant at Teepak, with a total investment on the order of $\$ 30$ million.

Biofiltration with gypsum production and disposal is by far the least costly option. If a biofiltration plant is to be built at Teepak, this option should be studied further. The actual rates of biological conversion of $\mathrm{H}_{2} \mathrm{~S}$ and $\mathrm{CS}_{2}$ need to be measured as functions of all variables, especially superficial velocity. These data can then be used to develop a detailed process flow diagram, as well as the design of all equipment components. Vendor quotes for all the equipment can then form the basis for developing an accurate economic analysis to replace the rough comparative estimate of this report. Since the economic viability of this option depends on gypsum disposal costs, the likely rate of escalation of landfill cost must also be a part of any future study. 


\section{REFERENCES}

1. McIntosh, M.J., 1992, Removal and Recovery of Carbon Disulfide Emitted by the Viscose Process: Final Report, ANL/ESD/TM-23, Argonne National Laboratory, Argonne, Ill.

2. Don, J.A., and L. Feenstra, 1984, "Odour Abatement through Biofiltration," in Proceedings of the International Symposium on Control of Odoriferous Pollutants, Louvain-la-Neuve, Belgium, April 25-27, 1984, Society Belge de Filtration, pp. 337-349.

3. Morales, V., et al., undated, "Biotechnological Process for Treatment of $\mathrm{H}_{2} \mathrm{~S}$ and $\mathrm{CS}_{2}$ from a Waste Gas from a Cellophane Plant," Environmental Division, Group CYDSA S.A. 66220, Graza Carcia, N.L., Mexico.

4. Moore, K.J., 1993, personal communication, Teepak, Inc., Danville, Ill.

5. Buisman, C., et al., 1990, "Optimization of Sulfur Production in a Biotechnological Sulfide Removing Reaction," Biotechnology and Bioengineering 35:50-56.

6. Ongcharit, C., et al., 1991, "Oxidation of $\mathrm{H}_{2} \mathrm{~S}$ by Flocculated Thiobacillus Denitrificans in a Continuous Culture," Biotechnology and Bioengineering 37:497-504.

7. Berzaczy, L., et al., 1988, "Biological Exhaust Gas Purification in Rayon Fiber Manufacture," Workshop on Recent Advances on Bioprocess Technology, Graz, Austria, March.

8. Torres-Cardona, M.D., et al., 1993, Biological Process for the Elimination of Sulphur Compounds Present in Gas Mixtures, U.S. Patent 5,236,677, Aug. 17.

9. Cork, D.J., 1985, "Microbial Conversion of Sulphate to Sulfur - An Alternative to Gypsum Synthesis," in Advances in Biotechnological Process 4, Alan R. Liss, New York, N.Y., pp. 183-209.

10. Duecker, W., and J. West, 1959, The Manufacture of Sulfuric Acid, Reinhold Publishing, New York, N.Y.

11. Encyclopedia of Chemical Technology, 1983, "Sulfuric Acid," 3rd ed., Vol. 22, John Wiley and Sons, New York, N.Y.

12. Chemical Economics Handbook Program, 1992, "Sulfuric Acid Supply and Demand - United States," Stanford Research Institute, Menlo Park, Calif. 
13. Chemical Marketing Reporter, 1991, "Chemical Profile of Sulfuric Acid," p. 35, Sept. 16.

14. Chemical Marketing Reporter, 1992, "Sulfuric Acid's 'Fragile' Balance," p. 3, May 18.

15. Chemical Marketing Reporter, 1992, "Sulfuric Acid Prices Reflect Industry Woes," p. 7, Nov. 23.

16. Chemical Marketing Reporter, 1992, "Gasoline Reform Lends New Life to Regen Sulfuric," p. 7, March 2.

17. Chemical Marketing Reporter, 1989, "Sulfuric Disappoints Expectations for 1989," p. 3, Aug. 7.

18. Chemical Marketing Reporter, 1993, "Fertilizers Face Crisis; DAP Pricing Hits New Low," p. 3, Feb. 22.

19. Chemical Marketing Reporter, 1990, "Sulfuric Healthy Despite Threats of Smelter Acid," p. 7, April 23.

20. Illinois Environmental Protection Agency, 1993, Illinois EPA Permitted Storage, Treatment, Recycling, Incinerating, and Processing Facilities, Bureau of Land, Springfield, Ill., March.

21. Chemsa, 1989, "Manufacture of Synthetic Gypsum From Limestone and Sulfuric Acid," p. 6, Jan. 1 .

22. Illinois Environmental Protection Agency, 1990, Special Waste Site List, Springfield, Ill., Jan. 1.

23. Susa, T., 1993, personal communication, Ionics, Inc., Watertown, Mass., May.

24. Aquatech ${ }^{\mathrm{TM}}$ Systems, Allied-Signal Inc., 1992, Bipolar Membrane Electrodialysis Technology for the Recycling of Waste Salts into Acids and Bases, presented at Membrane Technology and Wastewater Management Conference, Capetown, South Africa, March.

25. Encyclopedia of Chemical Technology, 1983, "Sulfur," 3rd ed., Vol. 21, John Wiley and Sons, New York, N.Y.

26. Chemical Marketing Reporter, 1993, "Sulfur's Long-Term Outlook: More is Needed," p. 3, April 6. 
27. Illinois Environmental Protection Agency, 1992, Title 35: Environmental Protection, Subtitle G: Waste Disposal, Chapter I: Pollution Control Board, Springfield, Ill., April.

28. Paul, P.G., and C. Roos, 1989, "Biological Waste Air Treatment with the Biobox," in Proceedings 8th World Clean Air Congress, Vol. 4, The Hague, Elsevier, Amsterdam, Holland, Sept. 11-15. 
APPENDIX A:

ASPEN PLUS OUTPUT 


\section{APPENDIX A:}

\section{ASPEN PLUS OUTPUT}

The flowsheet simulation capabilities of Aspen Plus are used to obtain a converged, numeric model of a processing plant. Thus, for each component of the plant, process flow rates, process conditions, physical properties of materials, and heat and work requirements are obtained. Equipment sizing and costing routines then estimate the cost to purchase each major piece of equipment, or "cost block," adjusted to include installation costs. Utility consumptions are also calculated for each cost block. Aspen Plus has cost models for most major equipment items. In the present case, Aspen Plus has been used to size and cost all equipment other than such specialty items as acid boilers. Specialty items are costed by using curves from Ulrich (1984) and other sources.

On the basis of the major installed equipment costs, utility usage rates, and factors compiled for the type of plant under consideration, Aspen Plus estimates the commodity costs (piping, concrete, steel, electrical, instrumentation, insulation, and paint). Costs for buildings and other unlisted equipment are obtained by using other factors. The capital costs of utility-generating equipment and storage facilities are generated by a correlation of previously compiled cost data, usually in the form of a power law. At this point in the capital-cost-estimating step, the total direct material and construction labor costs for the plant are estimated. These costs are then adjusted for inflation and project location, using internal Aspen Plus indexes. Site factors (site preparation, tax, freight rates, etc.) are estimated by applying appropriate factors to the total plant direct-material cost. Indirect costs (management, fees, insurance, etc.) are estimated by applying factors to the project costs. The total depreciable cost is obtained by adding a contingency allowance to the sum of the direct and indirect costs. The total fixed capital cost estimate is obtained by adding nondepreciable costs, for example, land and royalties.

The next step is estimation of both fixed and variable operating costs. Variable operation costs are utilities, raw material, waste treatment, and royalties. These costs are derived from user input of known costs. By-product credit is applied as a negative variable cost. Fixed operating costs are determined by factors applied to various elements of capital costs.

The Aspen Plus output for combined process simulation/economic analysis is contained on more than 50 pages for each individual plant. It is infeasible to include this many pages for the eight plants studied. Therefore, only the Aspen Plus summary pages are included in this appendix, along with the Aspen-Plus-generated process-flow diagrams (PFDs). Note that since these diagrams represent simulations, in some cases they may not appear to be equivalent to working process-flow diagrams for the plant in question. 


\section{REFERENCE}

Ulrich, G., 1984, A Guide to Chemical Engineering Process Design and Economics, John Wylie and Sons, New York, N.Y. 


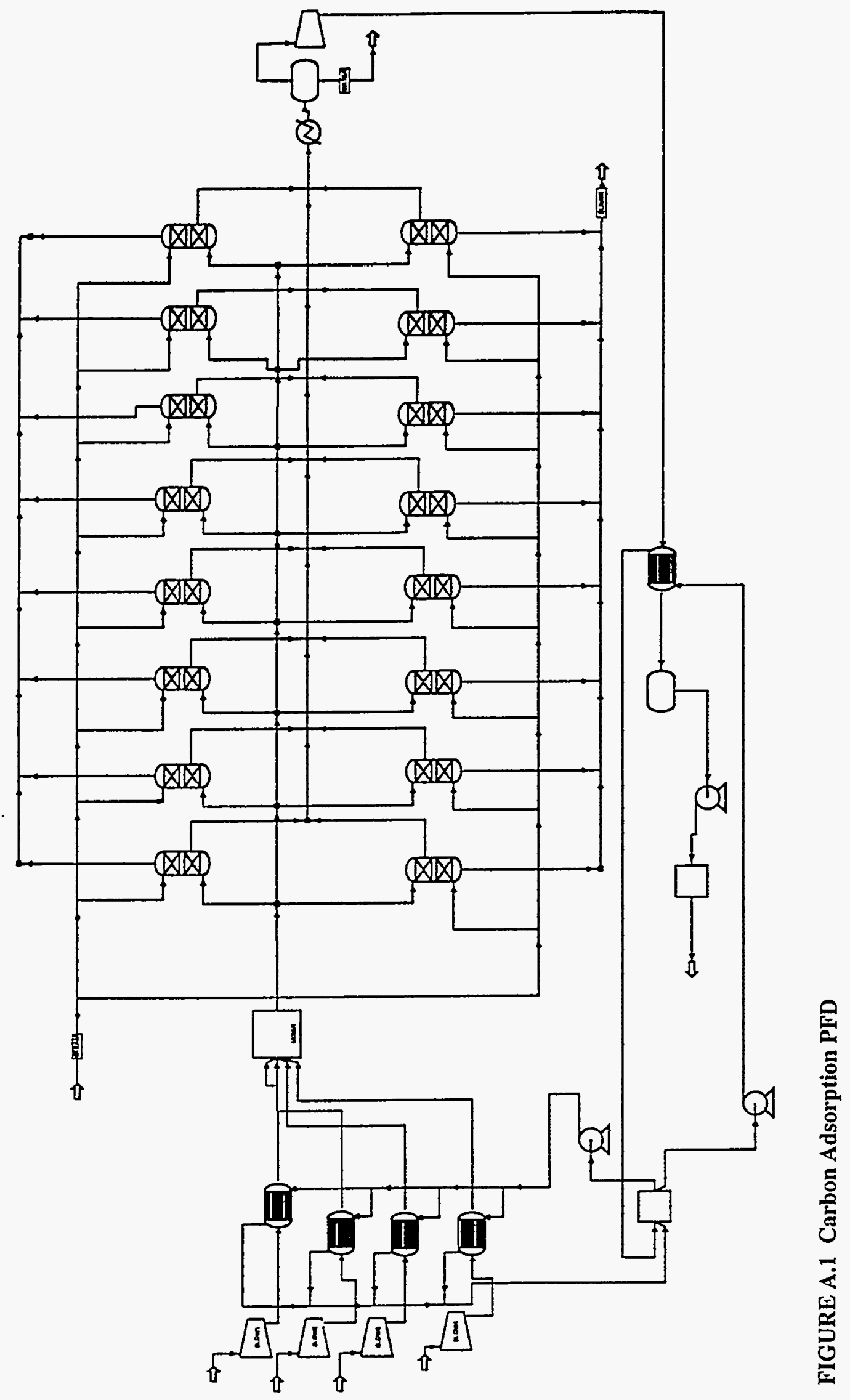


CARBON ADSORPTION PLANT FOR CS $_{2}$ REMOVAL - ECONOMIC EVALUATION

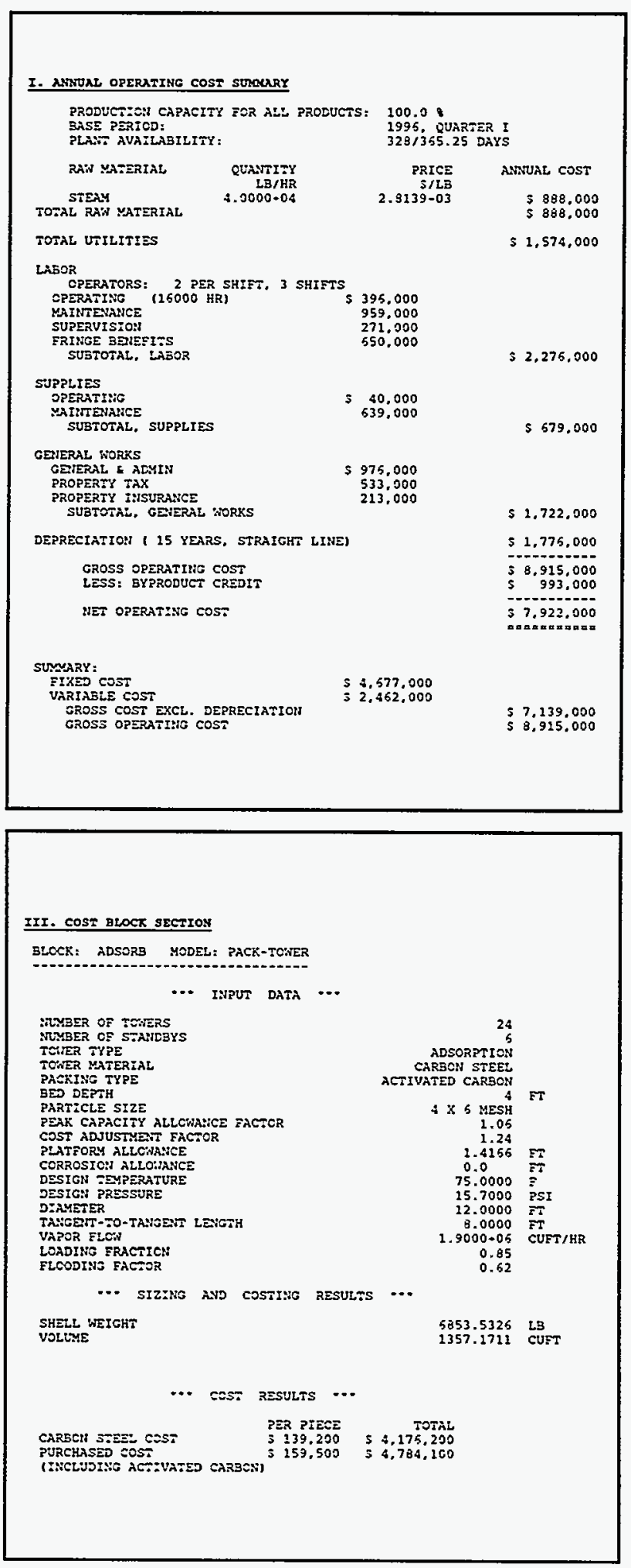

II. PROCESS OAIT DIRECT COST SUROURY

CCMPLETION: 1995, QUARTER I
LOCATICN: DAINILLE

$\cos r$ BLOCK ID

guANTITY

STANDSY

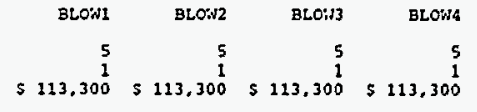

COST BLOCK ID

woume

QUANTITY
STANDBY

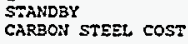

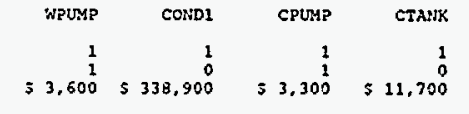

COST BLCCK ID

QUANTITY

STANDEY

$\begin{array}{ll}\text { CARBON STEEL COST } & \$ 4,175,200 \\ \text { PURCHASED COST } & 54,784,100 \\ \text { (IIMCLUDITG ACTIVATED CARBON } & \end{array}$

TOTAL EQUIPMENT COST S 5.594 .600

TOTAL INNESTMENT \$ 31,635,000

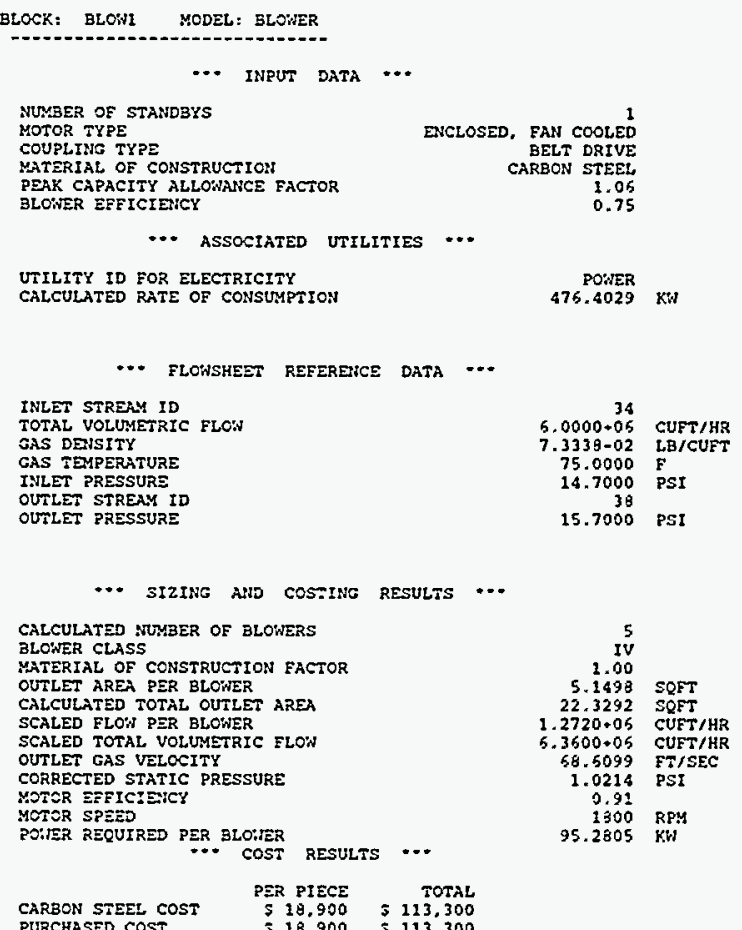




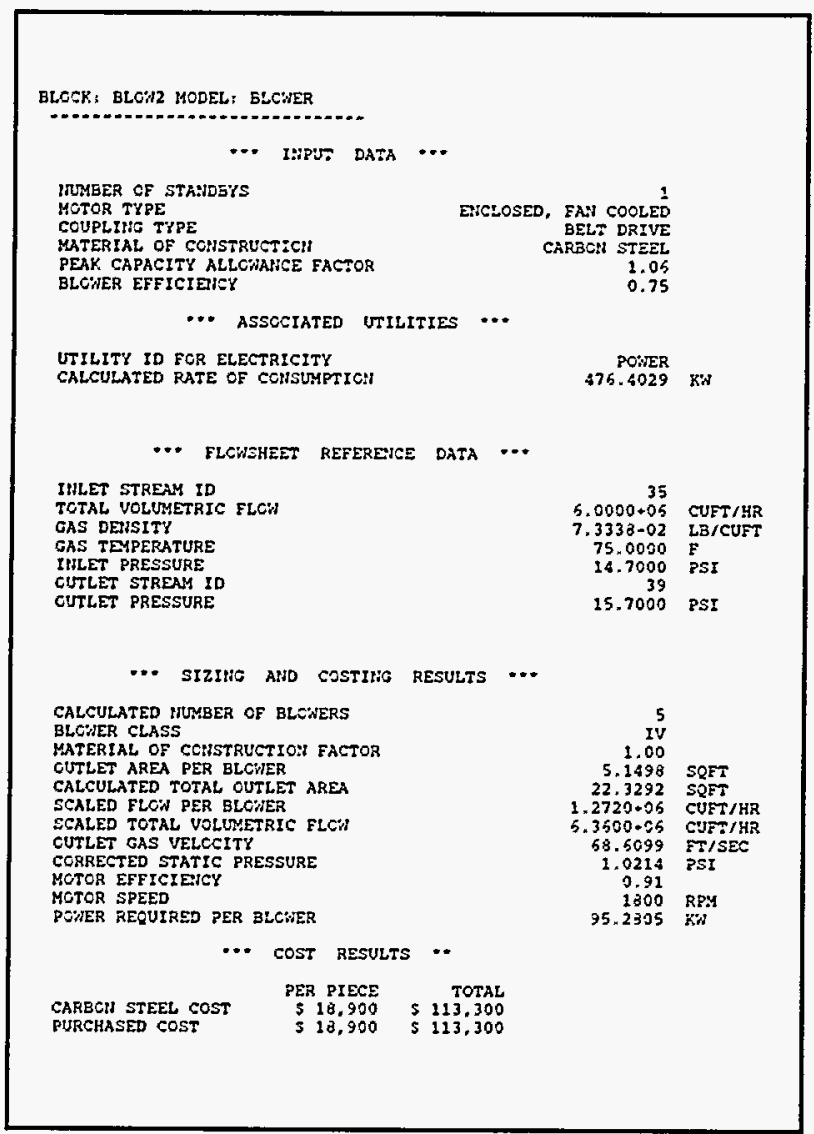

BLCEK: BLCWH MCOEL: BLCNER

$$
\text { -. Imput data } \cdots
$$

$\begin{array}{lr}\text { RNMBER OF STAHDBYS } & \\ \text { MCTOR TYPE } & \text { ENCLOSED, FAH COSLED } \\ \text { CNUPLIHG TYPE } & \text { BELT DRIVE } \\ \text { MATERIAL OF COHSTRUCTICH } & \text { CAREON STEEL } \\ \text { PEAK CAPACITY ALLCHANCE FACTOR } & 1.06 \\ \text { BLCHER EFFICIEHCY } & 0.75\end{array}$

-.. assceiated utilities $\cdots$

UTILITY ID FOR ELECTRICITY

CALCULATED RATE OF CCASIMPTICY

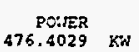

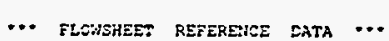

IIIET STREAM ID

TOTAL VOLWETREC FLEN

GAS TEMPERATURE

IILET PRESSURE

OUTLET STREAM ID
CUTLET PRESSURE

5. 0000.05 CUET/HR

$3333-02$ LB/CUET

75.0000
14.7000

25.7000 PSI

*. sizing and costing results ...

CALCULATED INMBER OF BLCMERS

GLCWER CLASS
MUTER:AL OF CEIISTRECTICH FACTOR

WUTLE:AL OF CCISTRECT!CH FACIOR

CALCULATES TOTAL CUTEE

SCALED FECN PER SLCWER
SCALED TOTAL VOLUMERIC FLOH

CUTLET GAS VELOCITY

CORRECTED STATIC PRESSURE

MOTOR EFE:CIE:IG

PUNER REEUTRED PER BLCJER

$$
\text { C. cest restits } \cdots
$$

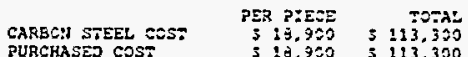

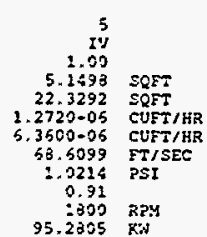

BLOCK: BLOII3 MODEL: BLCWER

$$
\text { -.. ImPUT Data } \cdots
$$
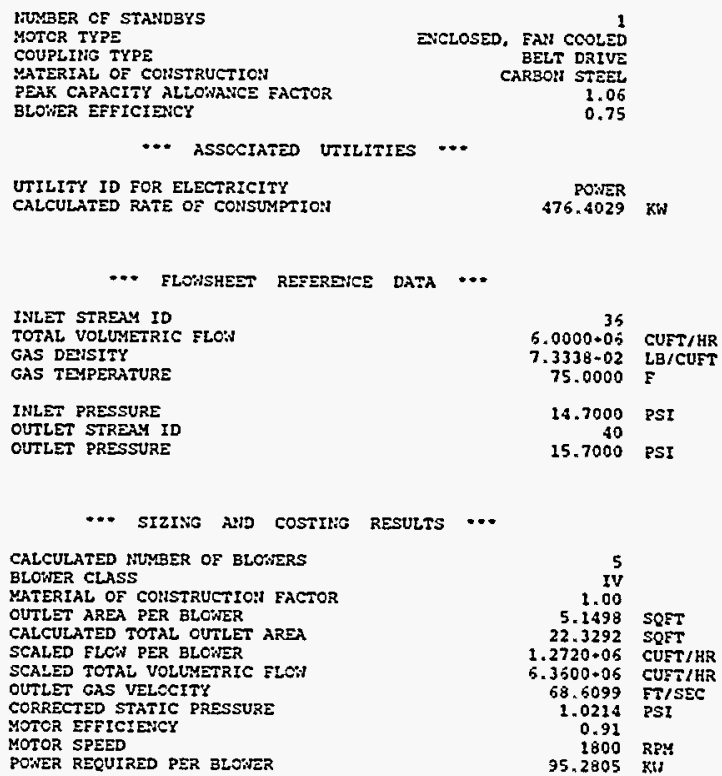

$\begin{array}{lrr} & \text { PER PIECE } & \text { TOTAL } \\ \text { CARBON STEEL COST } & 51 \mathrm{~A}, 900 & \$ 113.300 \\ \text { PURCHASED COST } & 518.900 & \$ 113.300\end{array}$

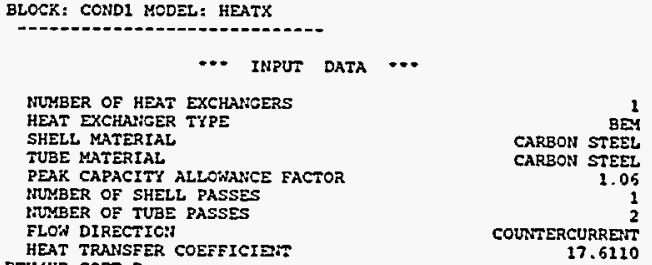

BLOCK: COND1 MODEL: HEATX

$$
\text { -.- inPUT DATA ... }
$$

MUREER OF HEAT EXCHANCERS

HEAT EXCHAAGER TYPE

SHELL MATERIAL

TUBE MATERIAL

MUMBER OF SHELL PASSES

FLO'N DIRECTIO

HEAT TRANSFER COEFFICIOTT

17.6110
17 RRT

BTU/HR-SQFT - R

$$
\text { ..- associated utilities ... }
$$

UTILITY ID FOR MATER

CALCULATED RATE OF COUSUMPTION

COOLH2O
$6 \times 5249 \cdot 05$ LB/HR

-.. FLONSHEET REFERERCE, DATA -..

BLCCK ID - SHELL STOE

SHELL PRESSURE

SHELL OUTLET TOYPERATURE

UTIEITY ID TUSE SIDE

TUBE PRESSURE

TUBE CUTLET TEYPERATURE

HEAT OUTY

... SIzING AND COSTIRG RESULTS ...

MATERIAL CE COHSTRUCTION EACTOR

KEAT TRAHSSFER AREA PER UNIT

TOTAL SCALED HEAT DUTY

ICO YEAN TZYPERATURE DIFFERENCE

$$
\text { ... COST RESULTS ... }
$$

CARSCN STEES GOST
BURCHSED COST
5338.900
$\$ 338.900$

COND1
14.7000 PSI

$\begin{array}{rl}350.0000 & \mathrm{E} \\ 80.0000 & \mathrm{~F}\end{array}$

CCOLH2O

14.6959 PSI

67.9100
1399100

4.5896007 sTU/HR

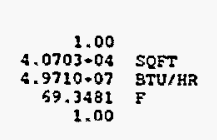

$.0703-04$ SQET

.3481 
CARBON ADSORPTION PLANT FOR $\mathrm{CS}_{2}$ REMOVAL - ECONOMIC EVALUATION

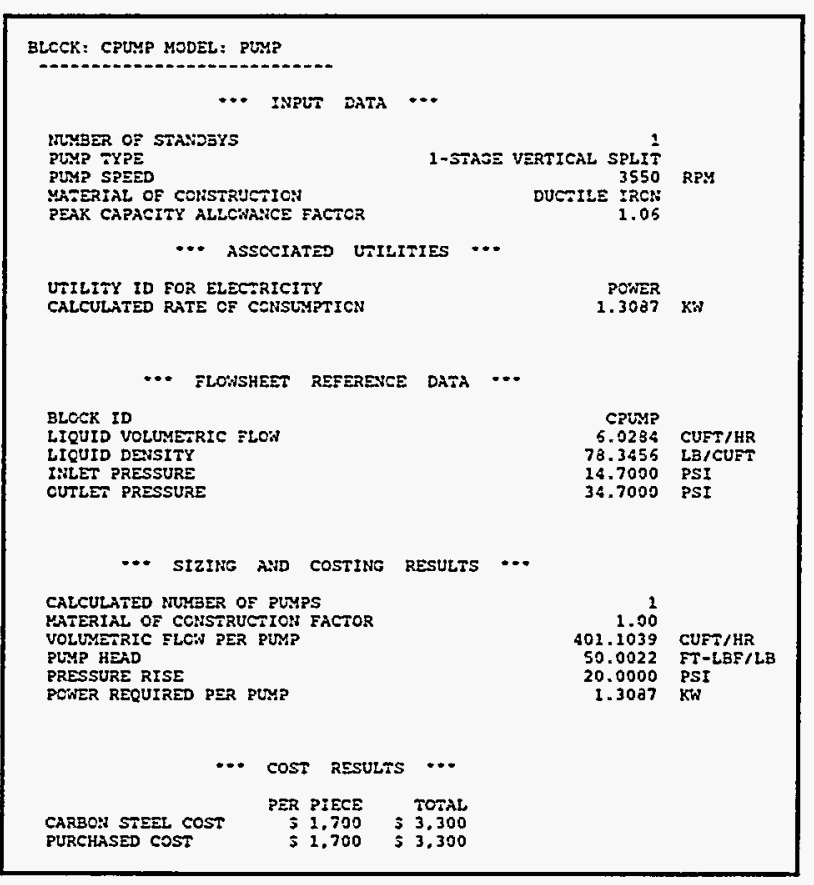

BLOCK: WPUMP MODEL: PUMP

\begin{tabular}{|c|c|c|c|}
\hline * :NPUT DATA & $\cdots$ & & \\
\hline $\begin{array}{l}\text { MUMER OF STANDBYS } \\
\text { PIMP TYPE } \\
\text { PUMP SPEED } \\
\text { MAIER COL OE CONSTRUCION } \\
\text { PEAX CAPACITY ALLOWANICE FACTOR }\end{array}$ & $1-$ StaG & $\begin{array}{r}\text { GE VERTICAL SPLIT } \\
3550 \\
\text { DUCTIEE } \begin{array}{r}1 \\
\text { SON } \\
1.06\end{array}\end{array}$ & RPM \\
\hline$\cdots$ ASSOCIATED UTILI & I2IEs $\cdots$ & •• & \\
\hline $\begin{array}{l}\text { UTILITY ID FOR ELECTRICITY } \\
\text { CALCULATED RATE OF COISUMPTIEN }\end{array}$ & & $\begin{aligned} \text { PONER } \\
1.7450\end{aligned}$ & $\mathrm{xw}$ \\
\hline$\cdots$ FLOWSHEET REFERENCE & $E$ DATA & $\cdots$ & \\
\hline $\begin{array}{l}\text { BLCCK ID } \\
\text { LIQUIS VOLUMETRIC ILCN } \\
\text { LIQUIS DENSITY } \\
\text { MHLET PRESSURE } \\
\text { OUTLET PRESSURE }\end{array}$ & & $\begin{array}{r}\text { HPUMP } \\
643.1512 \\
51.9749 \\
14.7000 \\
34.7000\end{array}$ & $\begin{array}{l}\text { CUET/HR } \\
\text { LB/CUFT } \\
\text { PSI } \\
\text { PSI }\end{array}$ \\
\hline -.. sIzING AHD costrng & RESULTS & $\cdots$ & \\
\hline 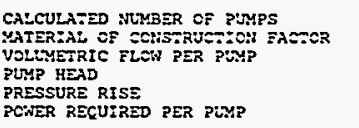 & & $\begin{array}{r}1.20 \\
587.9401 \\
50.0022 \\
20.0000 \\
1.7450\end{array}$ & $\begin{array}{l}\text { CUES/HR } \\
\text { FT-LBF/L3 } \\
\text { ZSI } \\
\text { KS }\end{array}$ \\
\hline$\cdots$ cest RESUEZS & $s \cdots$ & & \\
\hline 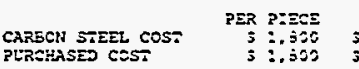 & 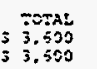 & & \\
\hline
\end{tabular}

PLRFHSED COST I :., 300 i 3.500

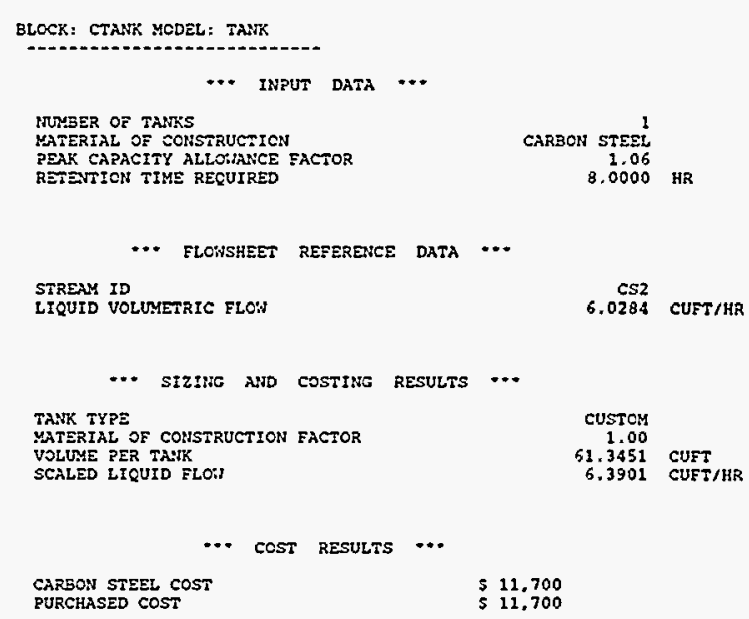

\section{UTILITY SECTYON}

UTILITY USACE: COOLH2O (WATER)

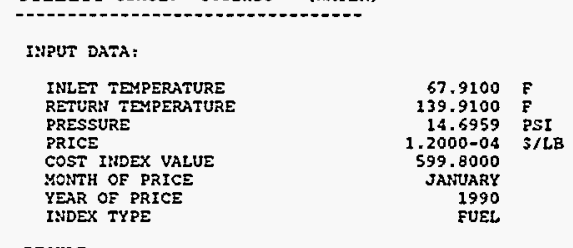

RESULT:

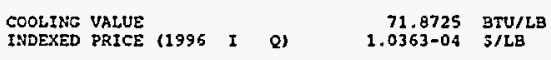

THIS VIILITY IS PURCHASED

USAGE:

\begin{tabular}{llrrr} 
COST BLOCK ID & YODEL & USAGE RATE (LB/HR $)$ & ANNUAL COST \\
\hline CONDI & HEATX & & $6.5249+05$ & -1533.445 \\
& & TOTAL: & $6.5249+05$ & 5533.445
\end{tabular}

UTILITY USAGE: POHER (ELECTRICTTY)

INPUT DATA :

PRICE

COST INDEX VALUE

MONTH OF PRICE

YEAR OF PRICE

INDEX TYPE

RESULT:

INDEXED PRICE (1996 I Q) 6.9084-02 \$/KHHR THIS UTILITY IS PURCHASED

USAGE:

COST BLOCK ID

BLoit

BLON1
BLON2
BLOW3

SLONA
CPUMP

CPUMP
APUMP

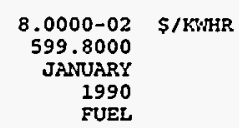




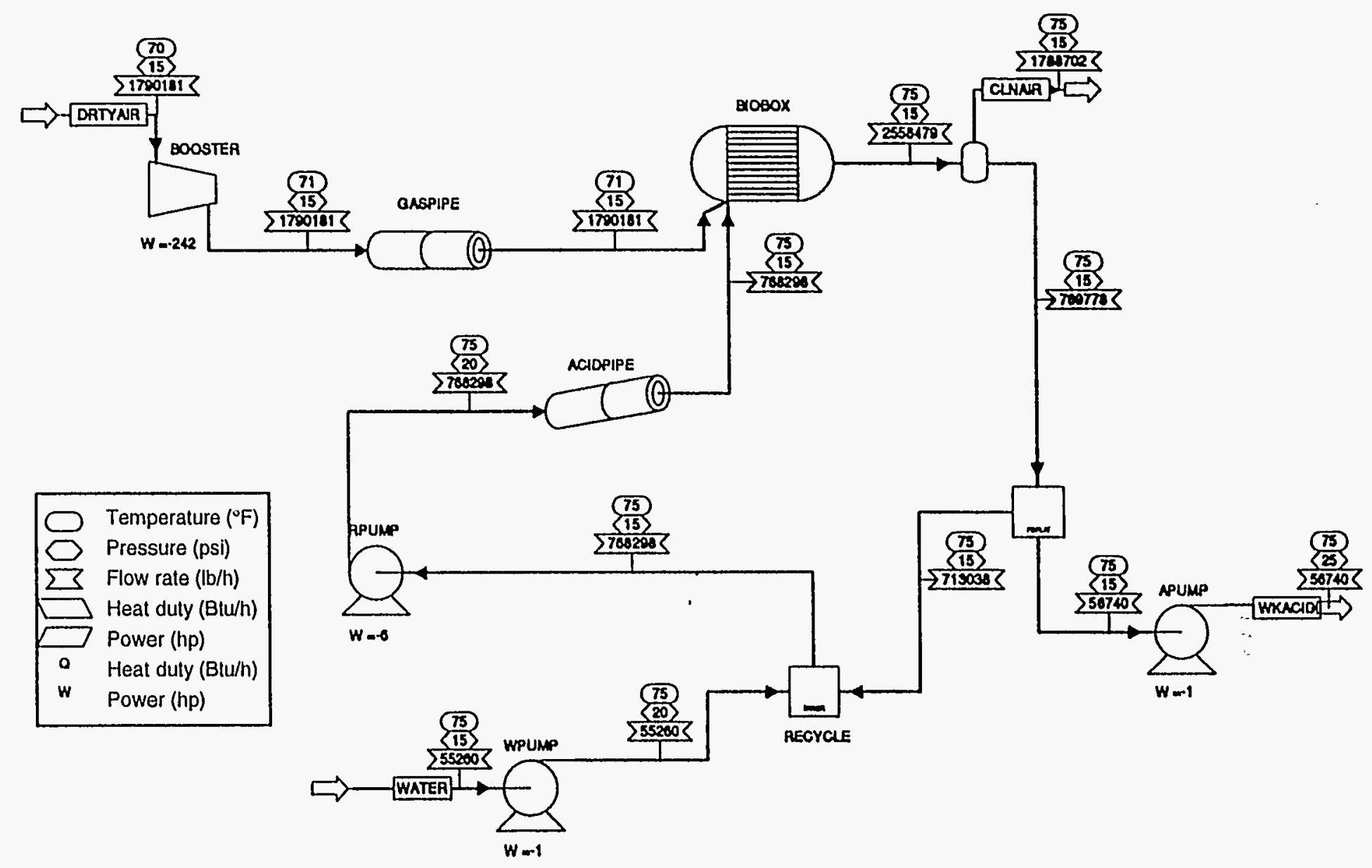

FIGURE A.2 Biofilter Plant PFD 
BIOFILTER PROCESS WITH $3 \% \mathrm{H}_{2} \mathrm{SO}_{4}$ WASTE - ECONOMIC EVALUATION

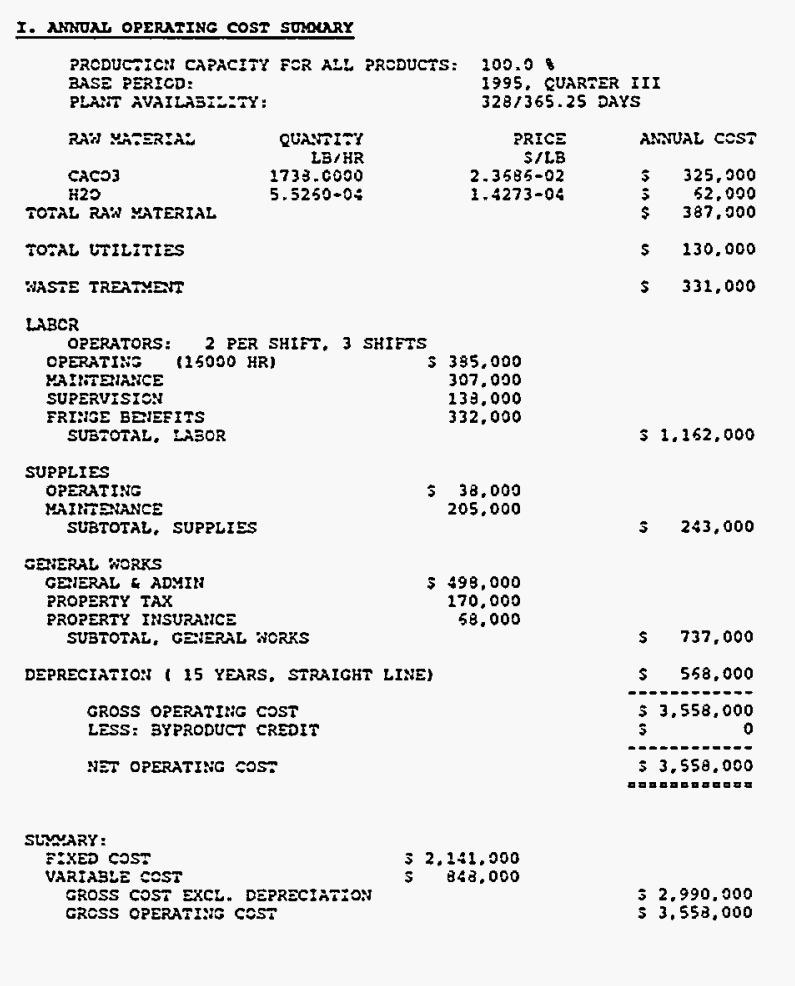

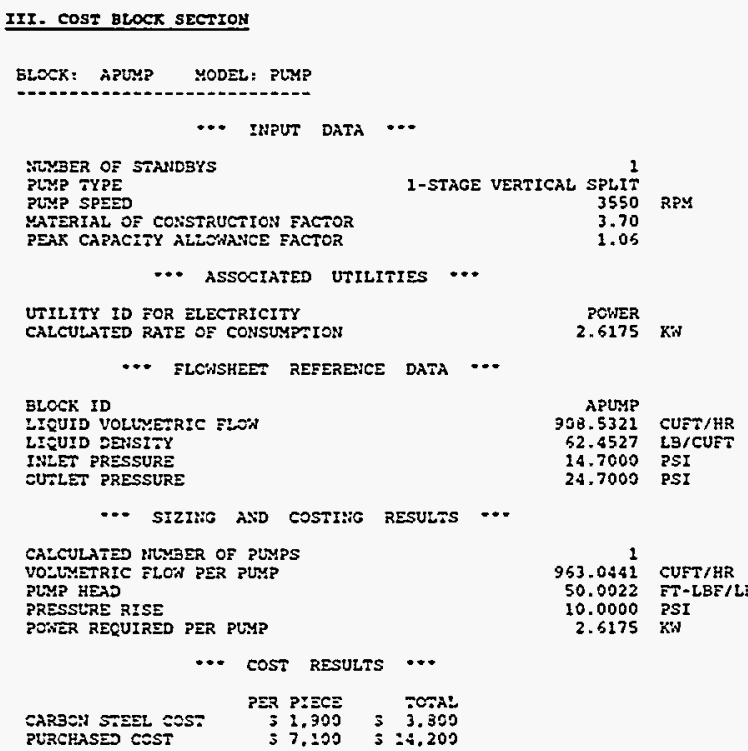

$\begin{aligned} 953.0442 & \text { CUFT/HR } \\ 50.0022 & \text { ET-LBEAL }\end{aligned}$

10.0000 PSI

\section{PROCESS UNIT DIRECT COST SOROQRRY}

COMPLETION: 1995. QUARTER III

LCCATION: DANVILLE

COST BLOCK ID

QUANTITY

STANDEY

CARBON STEEL COST

PURCHASED COST

COST BLCCK to

gUANITY

PURCHASED COST

TOTAL EQUIPMENT COST

TOTAL INVESTMENT
STANDBY

\begin{tabular}{|c|c|c|}
\hline APQTP & EIOBOX & BOOSTER \\
\hline s r $\begin{array}{r}1 \\
3,800 \\
5 \quad 14,200\end{array}$ & $\begin{array}{r}104 \\
0 \\
1.0711,500 \\
1,071,500\end{array}$ & 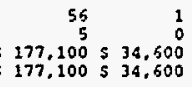 \\
\hline MIXER & RPUMP & WPUMP \\
\hline $\begin{array}{rr} & 1 \\
5 & 30.500 \\
5 & 106,500\end{array}$ & $\begin{array}{r}2 \\
1 \\
\$ \begin{array}{r}15,300 \\
56,500\end{array}\end{array}$ & $\begin{array}{r}1 \\
\$ 3 \\
33,800\end{array}$ \\
\hline \multicolumn{3}{|c|}{$=1.464,400$} \\
\hline & $8.592,000$ & \\
\hline
\end{tabular}

BLCCK: BCOSTER MODEL: BLOWER ... miput data $\cdots$

MMBER OF STANDBYS MOTOR TXPE

COUPLING TYPE

MATERIAL OE CONSTRUCTIO

PEAK CAPACITY ALLOAANCE FACTOR

$$
\text { -.. associated utilttics ... }
$$

ENCLOSED, FAN COOLED DELT DRIVE 1.05
0.75

UTILITY ID FOR ELECTRICITY

CALCULATED RATE OF CONSIMPTIOA

$$
\text { .. FLOWSHEET REFERENCE DATA } \cdots
$$

TNLET STREAM ID

GAS DENSITY

CAS TEMPERATURE

INLET PRESSURE

CUTEET PRESSURE

$$
\text { -.. sizing and costing results } \cdots
$$

PONER
$205.0794 \mathrm{KW}$

CALCULATED NUMBER OF BLCWERS

CONSTRUCTION FACTOR

CUTEE AREA FER BLCNER

CALCULATED TOTAL OUTLET AREA

SCALED FLCW PER BLOWER

SCALED TOTAL VOLUMETRIC FLOW

CUERET GAS VELOCITY

MOTOR EFFICIENCY

YOTOR SPEED
PCWER REQUIRED PER SLOHER

$$
\text { ... cost results ... }
$$

DRTYAIR

$\begin{array}{ll}2.3989+07 & \text { CUFT/HR } \\ 7.4624-02 & \text { LB/CUFT }\end{array}$

$7.4524-02 \mathrm{LB} / \mathrm{CU}$

$\begin{array}{ll}70.0000 & F \\ 14.7000 & \text { PSI }\end{array}$

$14.8000^{1}$ PSI

$\begin{array}{lrr} & \text { PER PIECE } & \text { TOTAL } \\ \text { CARBCN STEEL COST } & \$ 2.900 & \$ 177.100 \\ \text { PURCHASED COST } & \$ 2,900 & \$ 177.100\end{array}$

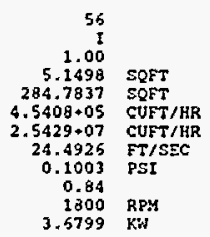

1800
3.5799
$\mathrm{KPM}$

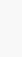




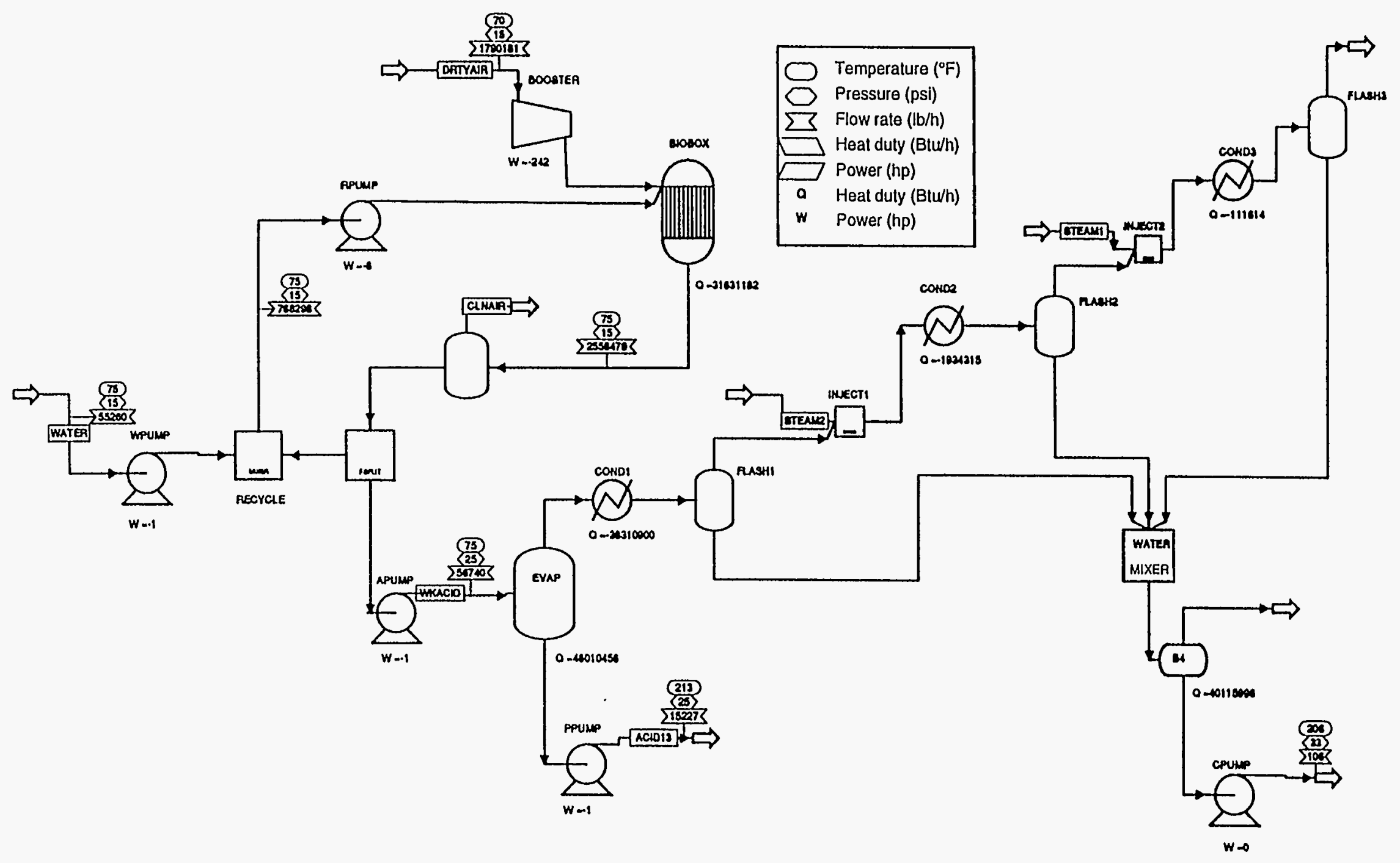

FIGURE A.3 Biofilter/Acid Concentrator (13\%) PFD 
BIOFILTER PROCESS CONCENTRATING TO $13 \% \mathrm{H}_{2} \mathrm{SO}_{4}$ - ECONOMIC EVALUATION

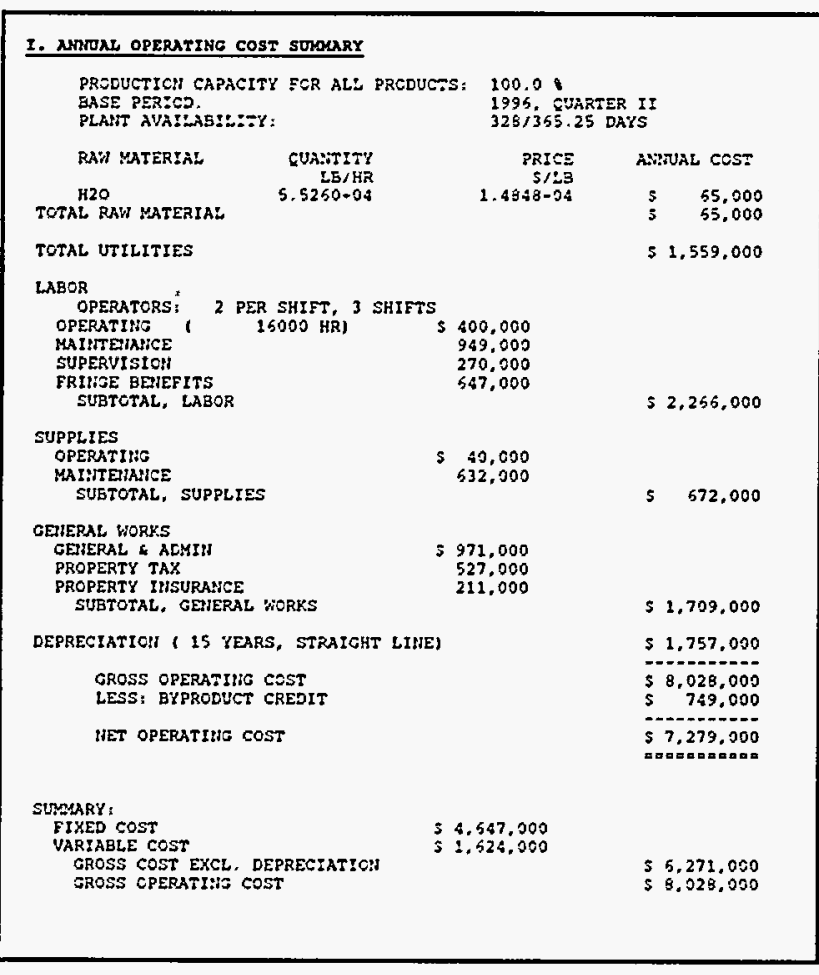

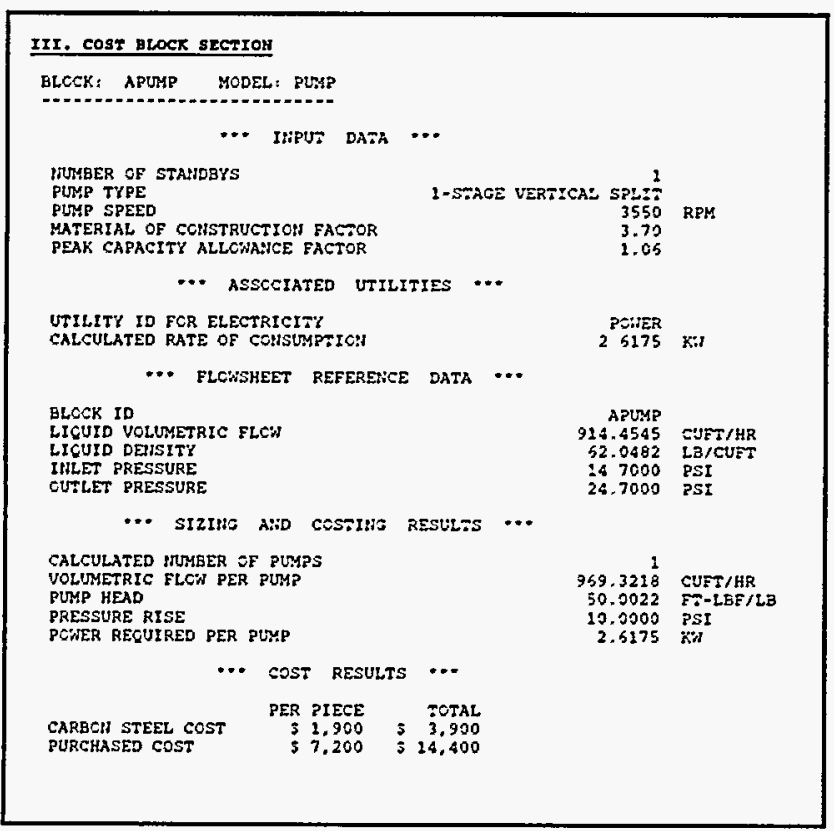

\begin{tabular}{|c|c|}
\hline \multicolumn{2}{|c|}{ II. PROCESS UNIT DIRECT COST SUROARRY } \\
\hline \multicolumn{2}{|c|}{$\begin{array}{l}\text { CCMPLETICH: 1995, QUARTER I } \\
\text { LOAATIOH: DARVILLE }\end{array}$} \\
\hline COST DLCek ID & BICSOX BONSTER \\
\hline $\begin{array}{l}\text { CUAMTISY } \\
\text { STANDEYY } \\
\text { CARBOR STEEL COST } \\
\text { PURCHASED COST }\end{array}$ & 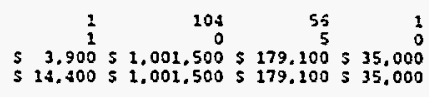 \\
\hline $\begin{array}{l}\text { COST BLCCK ID } \\
\text { QUANTITY } \\
\text { STANDBY } \\
\text { CARBON STEEL COST } \\
\text { PURCHAED COST }\end{array}$ & 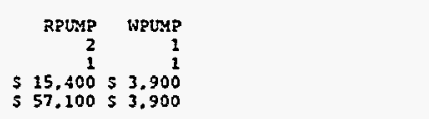 \\
\hline $\operatorname{cost}$ BLOCK ID & COND1 COND2 CORDJ CRUMP \\
\hline $\begin{array}{l}\text { QUANTITY } \\
\text { SAANDSY } \\
\text { CARBON STEEL COST } \\
\text { PURCHASD COST }\end{array}$ & 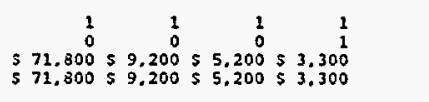 \\
\hline COST 3LOCK ID & CTIK SVAP1 INJECTI IRJECT2 \\
\hline $\begin{array}{l}\text { QUAATITY } \\
\text { STANDBY } \\
\text { CARBCN STEEL COST } \\
\text { PURCHASED COST }\end{array}$ & 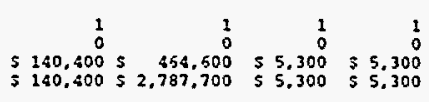 \\
\hline 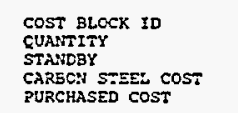 & 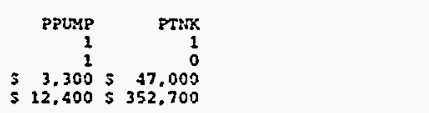 \\
\hline TOTAL EQUIPHET: COST & $=4.584 .500$ \\
\hline TCTAL IMUESMET & $\$ 26.375 .000$ \\
\hline
\end{tabular}

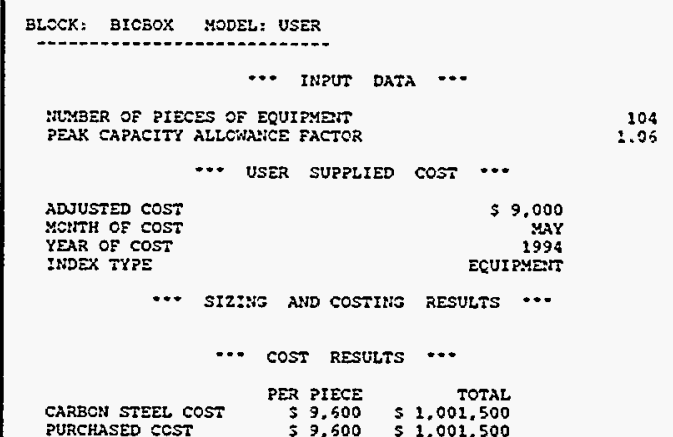


BIOFILTER PROCESS CONCENTRATING TO $13 \% \mathrm{H}_{2} \mathrm{SO}_{4}$ - ECONOMIC EVALUATION

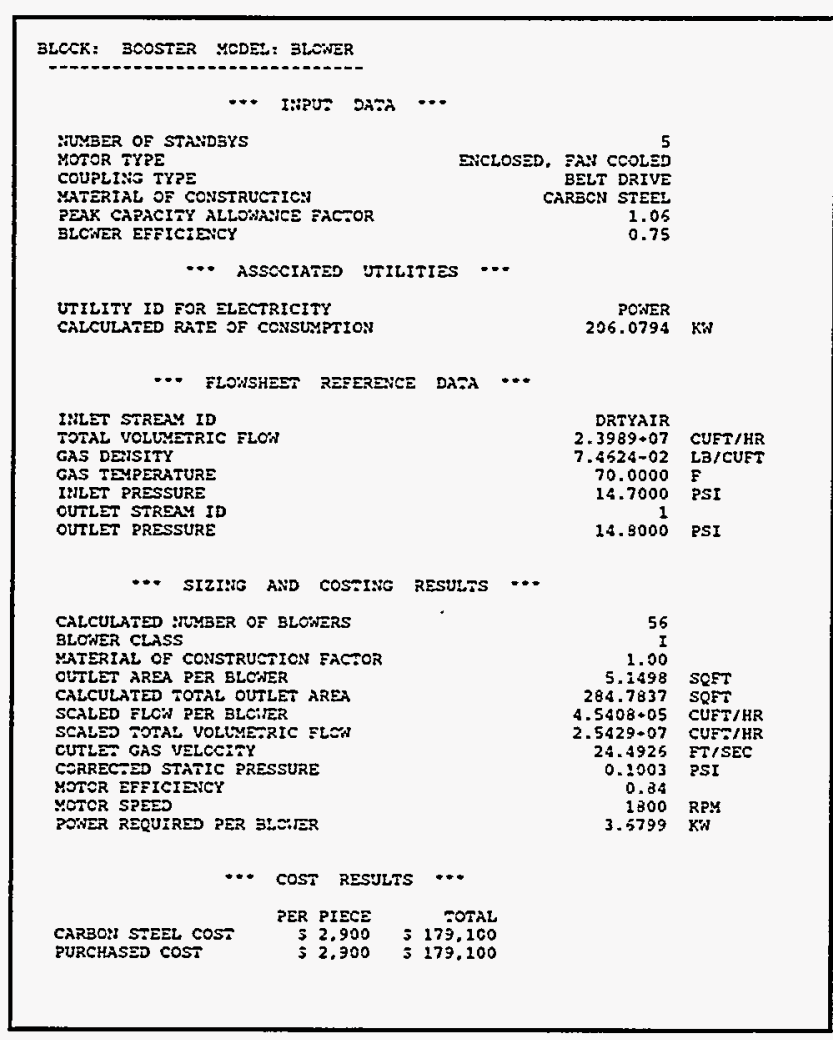

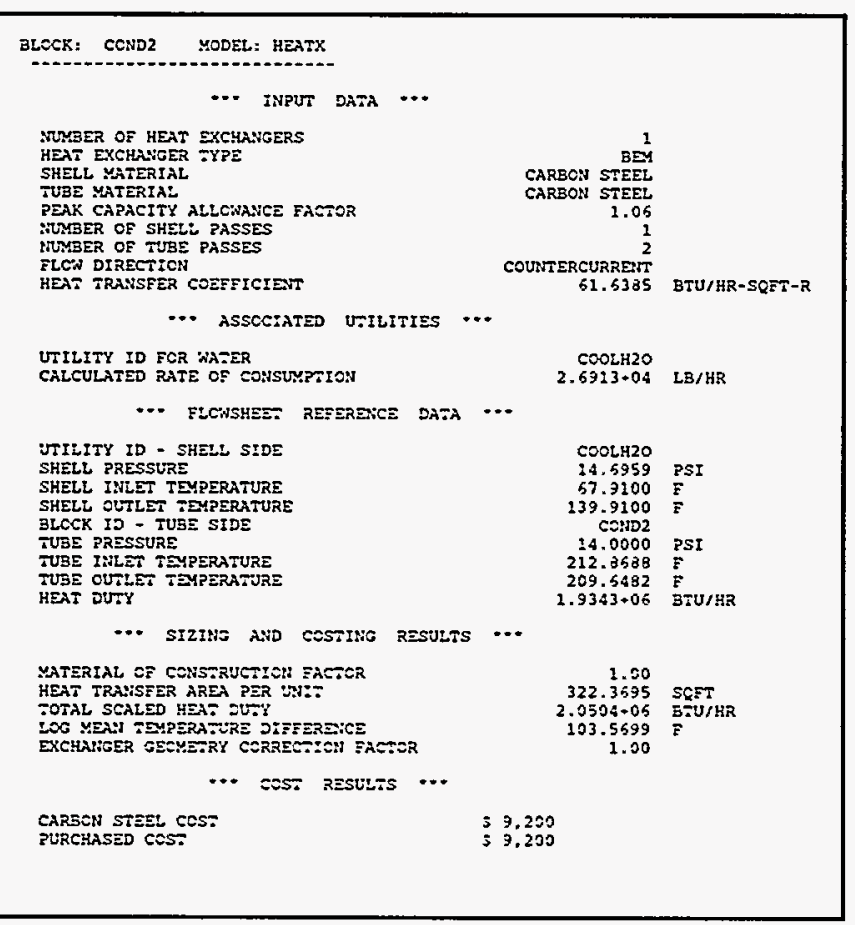

\begin{tabular}{|c|c|c|}
\hline BLOCK: COND1 MODEL: HEATX & & \\
\hline$\cdots$ INPG DATA $\cdots$ & & \\
\hline 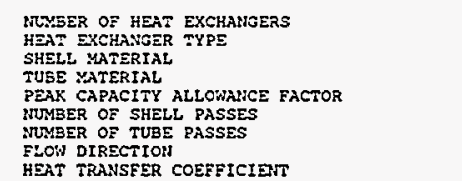 & $\begin{array}{r}12 \\
\text { BEM } \\
\text { CAREON STEEL } \\
\text { CARBON STEEL } \\
1.06 \\
1 \\
2 \\
\text { COUMTERCURRENT } \\
51.6385\end{array}$ & $\mathrm{BTU} / \mathrm{HR}-\mathrm{SPFT}-\mathrm{R}$ \\
\hline$\cdots$ associated vitutties . & $\cdots$ & \\
\hline $\begin{array}{l}\text { UTILTTY ID FOR WATER } \\
\text { CALCULATED RATE OE CONSLYMPTION }\end{array}$ & $\begin{array}{r}\cos 2420 \\
5.3304+05\end{array}$ & LB/HR \\
\hline ... FLONSHEET REFERENCE DATA & $\cdots$ & \\
\hline 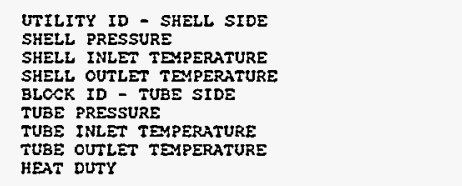 & $\begin{array}{r}\text { COOL.H2O } \\
14.6959 \\
57.9100 \\
139.9100 \\
60.901 \\
144.7000 \\
213.2608 \\
212.1040 \\
3.8311 .07\end{array}$ & $\begin{array}{l}\text { PSI } \\
F \\
F \\
\text { PSI } \\
F \\
g \\
B T U / H R\end{array}$ \\
\hline ... SIZTNG AND COSTING RESULTS & $\cdots$ & \\
\hline $\begin{array}{l}\text { MATERIAL OF COHSTRUCTIOAI FACTOR } \\
\text { HEAT TRANSFER AREA PPR UNIT } \\
\text { TOTAL SCALED HEAT DUTY } \\
\text { LOC MEMI TEMPEATURE DIFFEREICE } \\
\text { EXCHANGER GEONETRY CORRSCTION FACTOR }\end{array}$ & $\begin{array}{r}1.00 \\
6285.8468 \\
4.0510+07 \\
104.8122 \\
1.00\end{array}$ & $\begin{array}{l}s Q F T \\
\text { BTU/HR } \\
F\end{array}$ \\
\hline$\cdots$ COST RESULTS $\cdots$ & & \\
\hline $\begin{array}{l}\text { CARBON STEEL COST } \\
\text { PURCHASED COST }\end{array}$ & $\begin{array}{l}571,800 \\
571,800\end{array}$ & \\
\hline
\end{tabular}

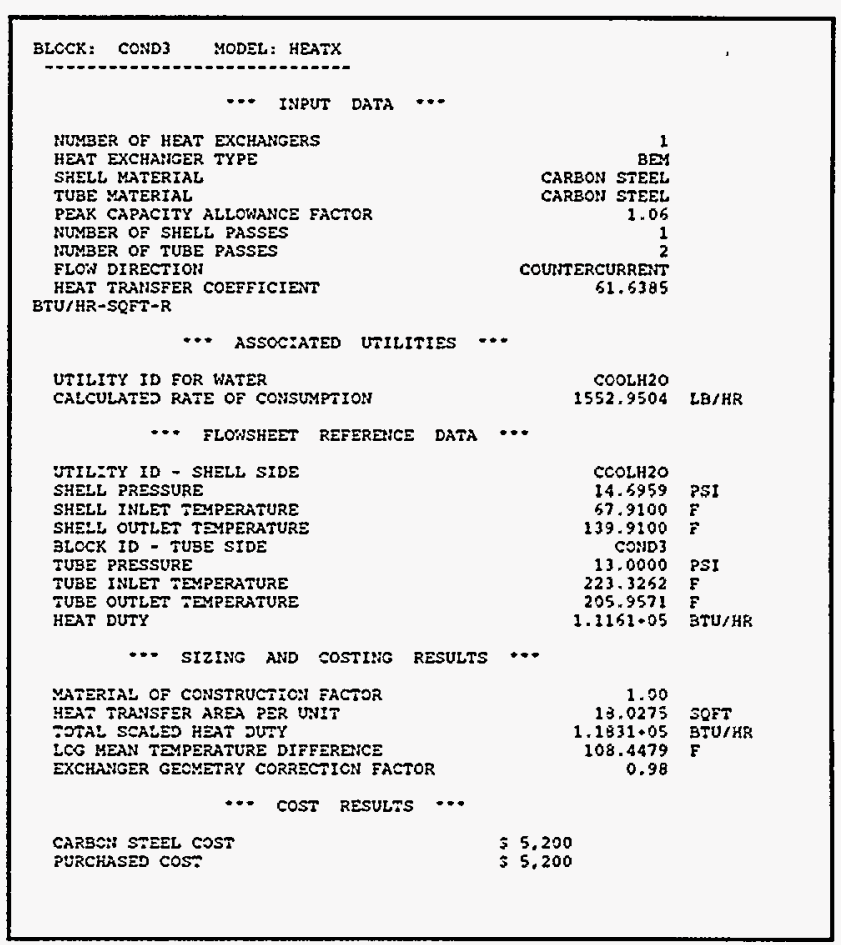




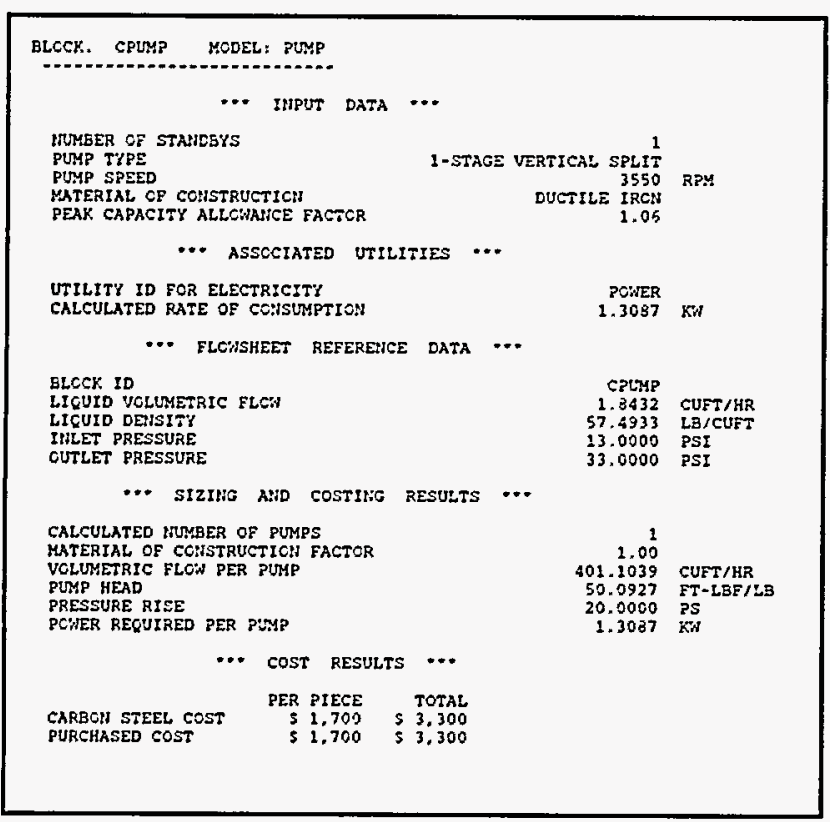

\begin{tabular}{|c|c|c|}
\hline BLCEK: EVAP1 YYDEL: HEATX & & \\
\hline \multicolumn{3}{|l|}{3484 SGFT ZIRCCMITM EVAPORATOR } \\
\hline$\cdots$ IMPUT DATA $\cdots$ & & \\
\hline 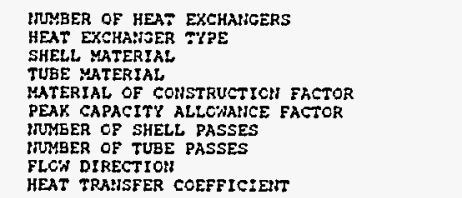 & $\begin{array}{r}1 \\
\text { BEY } \\
\text { CARBEA STEEEL } \\
\text { CARECN STEEL } \\
5.00 \\
1.05 \\
1.05 \\
1 \\
2 \\
\text { COURTERCURREVT } \\
70.4440\end{array}$ & BTU/HR-SQFT-R \\
\hline 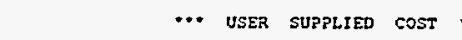 & $\cdots$ & \\
\hline $\begin{array}{l}\text { BASE COST } \\
\text { COST YMDEX VALUE } \\
\text { IMDEX TYPE }\end{array}$ & $\begin{array}{r}350.000 \\
315: 000 \\
\text { EQUIPMET }\end{array}$ & \\
\hline ... AsScelated vTILITIES . & $\cdots$ & \\
\hline $\begin{array}{l}\text { VTHLITY ID FOR STEAM } \\
\text { CALCULATED RATE OF COUSUMPTYO }\end{array}$ & $\begin{array}{l}\text { STERM1 } \\
5.5514 .04\end{array}$ & EB/HR \\
\hline 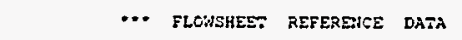 & $\cdots$ & \\
\hline 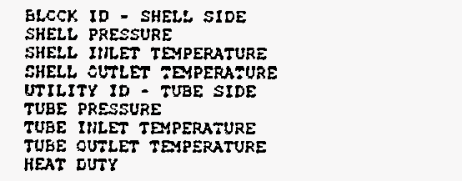 & $\begin{array}{r}\text { EVAP } \\
14.7000 \\
75.0574 \\
213.2508 \\
5525911 \\
150.0000 \\
35.4353 \\
353.4353 \\
4.3010 .07\end{array}$ & $\begin{array}{l}\text { PSI } \\
F \\
F \\
F \\
P S I \\
F \\
F \\
F \\
B T U / H R\end{array}$ \\
\hline 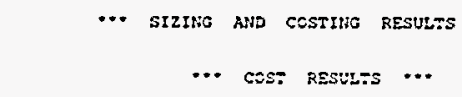 & $=\cdots$ & \\
\hline $\begin{array}{l}\text { CARECH STEEL COS: } \\
\text { PURCHASES COST }\end{array}$ & 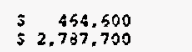 & \\
\hline
\end{tabular}

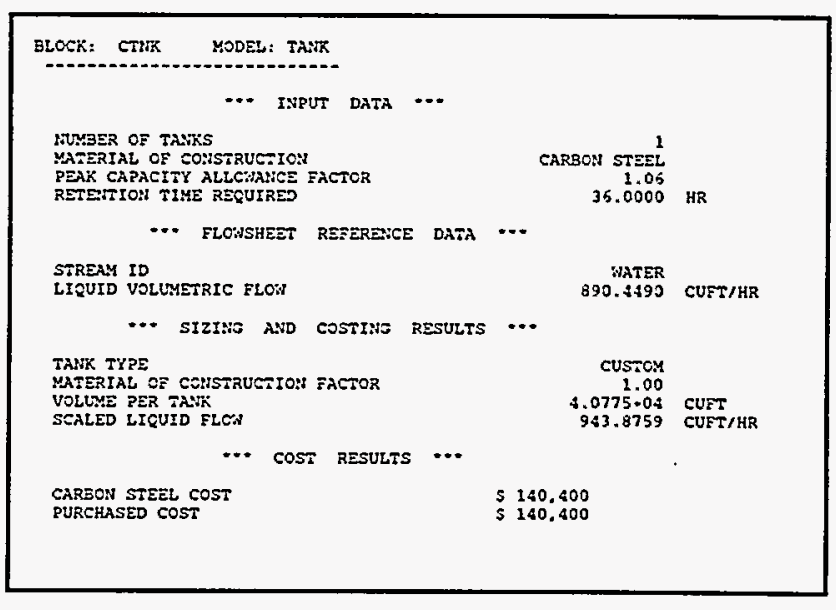

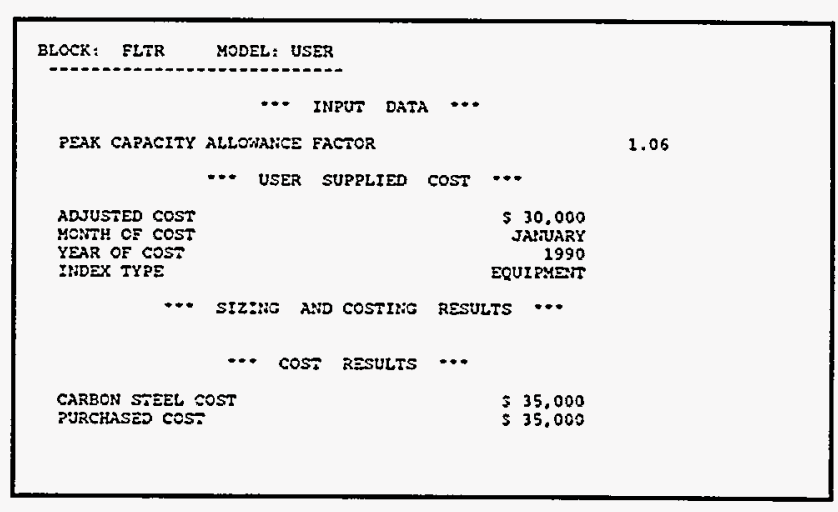

\begin{tabular}{|c|c|}
\hline$\cdots$ IMPUT DATA $\cdots$ & \\
\hline 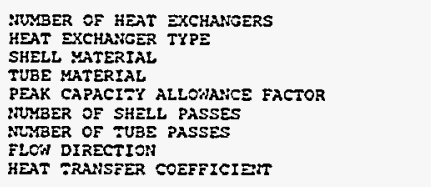 & $\begin{array}{r}\text { BEY } \\
\text { CARBO:I STEEL } \\
\text { CARBOA STESE } \\
1.05 \\
1 \\
\frac{1}{2} \\
\text { COUNTERCURREVT } \\
79.2495 \text { ETU/HR-SQET-R }\end{array}$ \\
\hline$\cdots$ USER SUPPLIED COST & $\cdots$ \\
\hline $\begin{array}{l}\text { ADUUSTED COST } \\
\text { YEAR OF COST } \\
\text { IMDEX TYPE }\end{array}$ & $\begin{aligned} 55,000 \\
i 984 \\
\text { EQU1PYENT }\end{aligned}$ \\
\hline 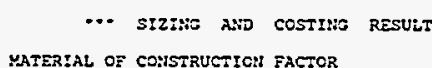 & s $\cdots$ \\
\hline$\cdots$ COST RESULTS $\cdots$ & \\
\hline $\begin{array}{l}\text { CARBON STEE: COSZ } \\
\text { PURCHASED COST }\end{array}$ & $\begin{array}{l}55.300 \\
\$ 5,300\end{array}$ \\
\hline
\end{tabular}


BIOFILTER PROCESS CONCENTRATING TO 13\% $\mathrm{H}_{2} \mathrm{SO}_{4}$ - ECONOMIC EVALUATION

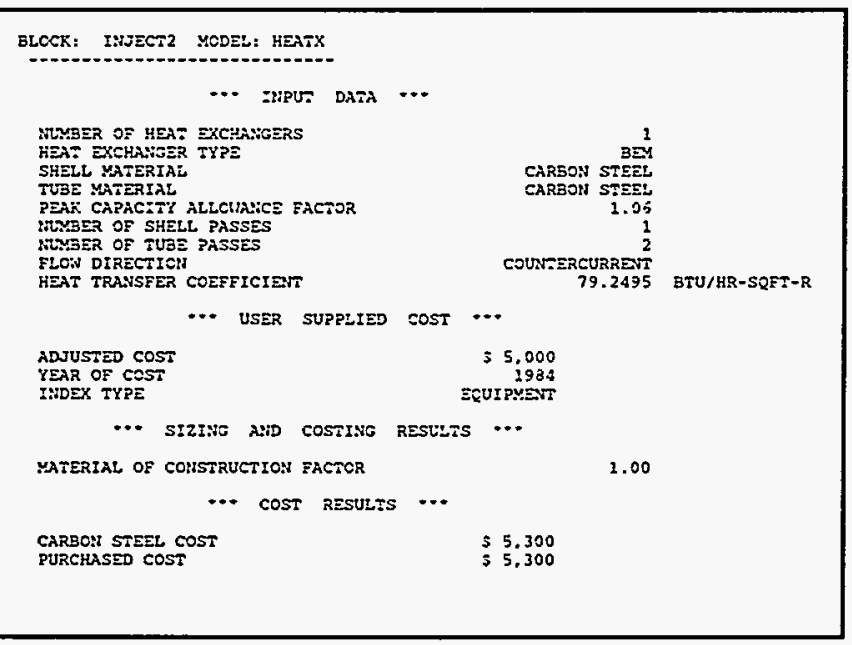

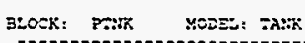

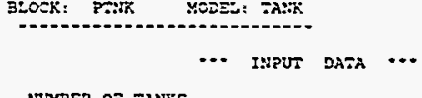

MYSER oF TANR

PEAK CAPACITY ALLCWAMEE FACTCR

RETETIOA THE REQUIRED

-.. FLONSHEET REFERENCE DATA $\cdots$

STREAY ID
L:QUID VOLLYETRIC ELCW

-.. sizing and costing REsults $\cdots$

TAMK TYPE

THE CCISTRUCTICM FACTOR

VOLLME PER TANK
SCALED LICUID FLON

$\cdots$ cost RESULts $\cdots$

$\begin{array}{ll}\text { CARBOR STEEL COST } & \$ 47,000 \\ \text { PURCHASED COST } & \text { \$ } 352,700\end{array}$

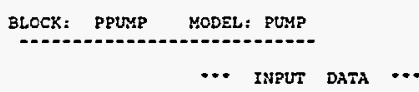

BLOCK: PPUMP MODEL: PUMP

-.. InPUT DATa ...

MMBER OF STANDBYS

PUMP TYPE

MATERIAL OF CONSTRUCTION FACTOR

MATERIAL OF CONSIRUCTIOA FACTOR

$1-$ STAGE VERTICAL SPEIT
3550
3.70
3.06 RPM

..* asscciated vitlities ...

$\begin{array}{lrl}\text { UTILITY ID FOR ELECTRICITY } & \text { PCIRER } \\ \text { CALCULATED RATE OF CONSUMPTION } & 1.3007 & \mathrm{KW}\end{array}$

-.. ELCNSHEEt REFERENCE dATA ...

BLock ID

LIQUID VOLUMETRIC FLOI

LIQUID DENSITY

TRLET PRESSURE

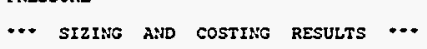

CALCULATED INMBER OF PUMPS

VOLUMETRIC FLON PER PUMP

PLMP HEAD

PONER REQUIRED PER PUME

$1.3007 \mathrm{kN}$

$\begin{aligned} \text { PPUMP } & \\ 265.51 \% 2 & \text { CUFT/HR } \\ 57.3259 & \text { LB/CUFT }\end{aligned}$

$\begin{array}{ll}57.3259 & 2 B / C J P \\ 14.7000 & \text { PSI }\end{array}$

24.7000 PSI

$\begin{aligned} 1 & \\ 401.1039 & \text { CUFT/HR } \\ 50.0022 & \text { FT-LBF/LB }\end{aligned}$

10.0000 PSI
1.3087 KW

-.. cost RESULTS …

CARBON STEEL COST PER PIECE 3 TOTAL

$\begin{array}{lll}\text { CARBONS STEEL COST } & \$ 1,700 & \$ 3,300 \\ \text { PURCHASED COST } & \$ 5,200 & \$ 12,400\end{array}$

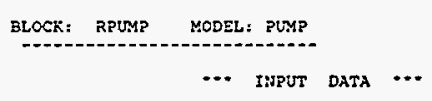

NLMBER OF STANDBYS

PUMPER TYPE 1
1-STAGE VERTICAL SPLIT
3550
3.70
1.06 RPM

PUMP SPEED

PEAK CAPACITY ALLONANCE FACTOR

... asscctated utrLities $\cdots$

CUSTOM
7.50

$\begin{aligned} 2702.9315 & \text { CUFT } \\ 281.5553 & \text { CUFT/HR }\end{aligned}$

UTILITY ID FOR ELECTRICITY

CALCULATED RATE OF CONSLMPTION

PCWER
$34.1080 \mathrm{KW}$

‥ FLOWSHEET REFERENCE DATA ‥

BLCCK ID

iIOUID VOLUMETRIC FLON

LIQUID SENSITY

OULET PRESSURE

... sizing and costing Results $\cdots$

CALCULATED MUMBER OF PUMPS

TOTAL SCALED VOLUMETRIC FLO

VOLUMETRIC FLOW PER PUMP

PLMP HEAD

PRESSURE RISE
POWER REQUIRED PER PUMP

$$
\text { -. cost results } \cdots
$$

$\begin{array}{lcr} & \text { PER PIECE } & \text { TOTAL } \\ \text { CARBON STEEL COST } & 55.100 & \$ 15,400 \\ \text { PURCHASED COST } & 319,000 & 557,100\end{array}$
RPUMP
$1.2382 * 04$
CUFT/H

52.0503 LB/CUFT

$\begin{array}{ll}14.7000 & \text { PSI } \\ 19.7000 & \text { PSI }\end{array}$

$1.3125 .04 \mathrm{CUFT} / \mathrm{HR}$

5562.3723 CUFT/HR

$50.0022 \quad F T-L B F / L B$

5.0000
17.0540 


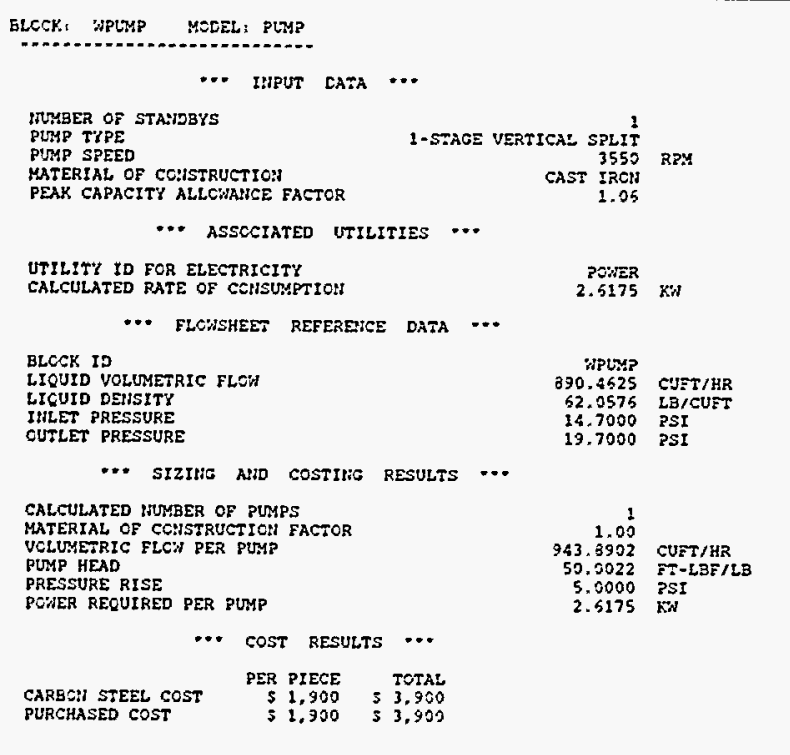

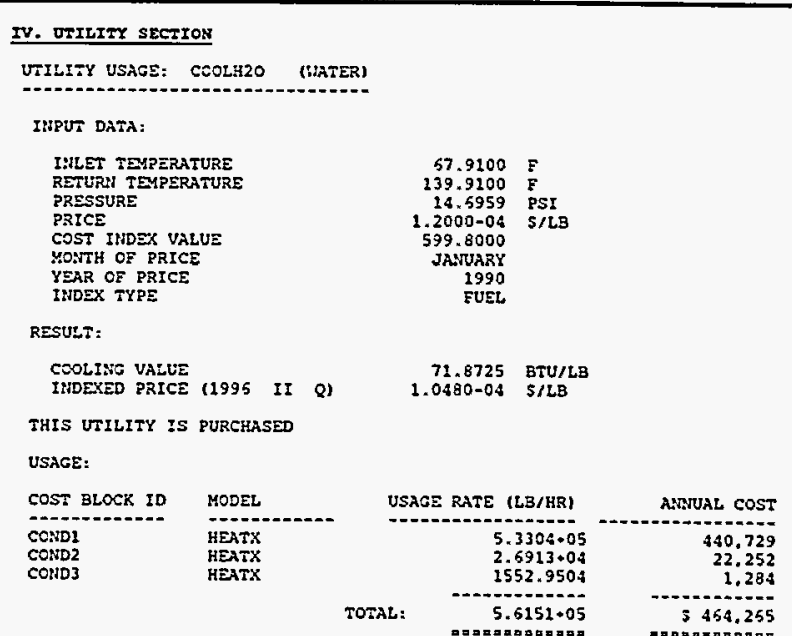

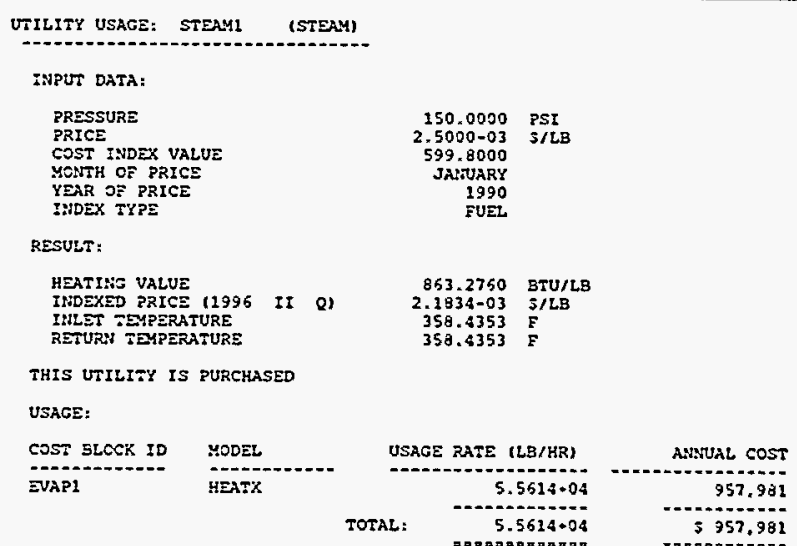$$
\text { gVAP }
$$

COST BLCCK ID

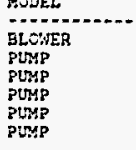

USAGE RATE $(K N)$

2.5125
1.3587
1.3087

34.1030
2.5175

248.0401

ANsual cos: 


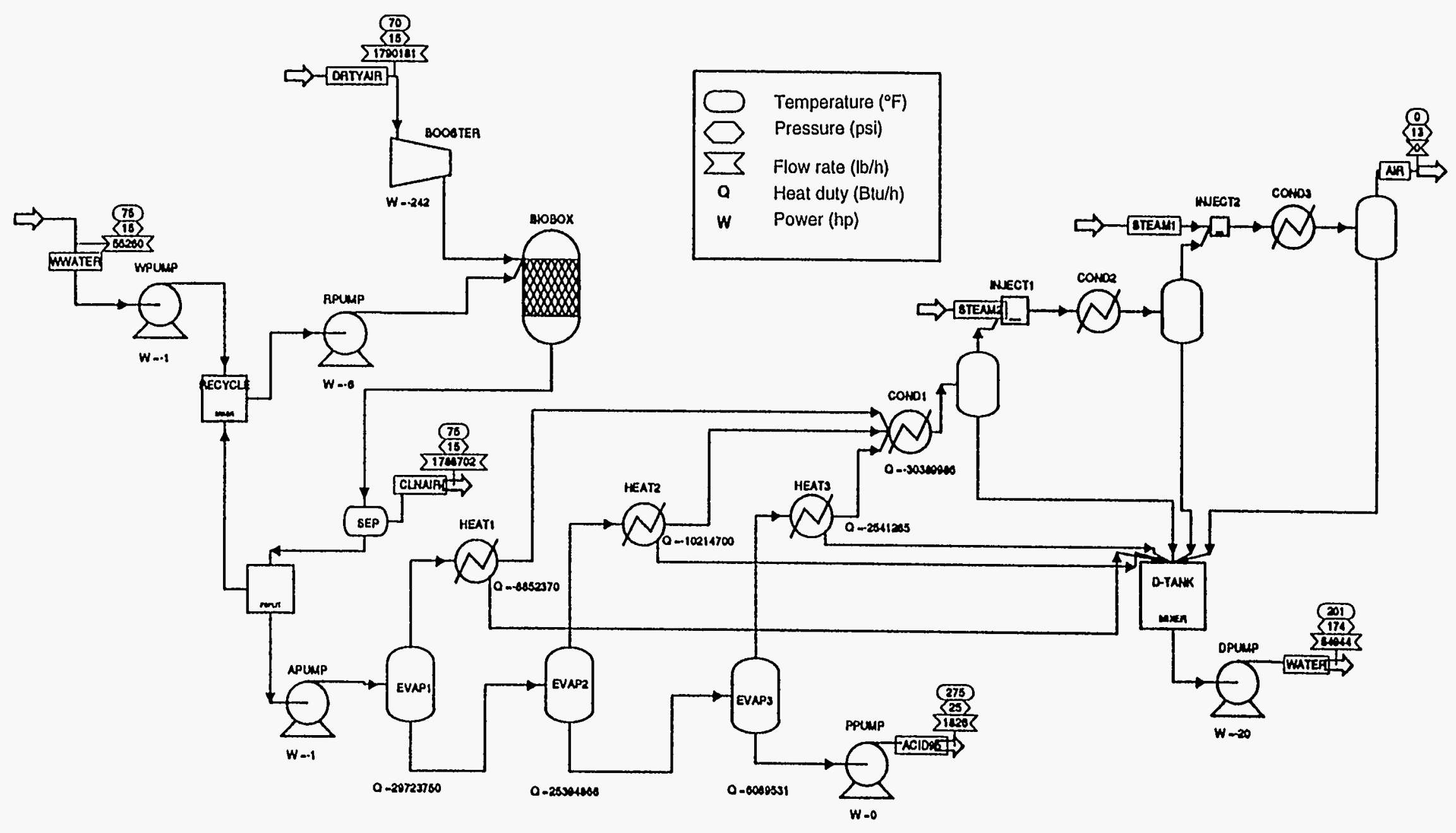

FIGURE A.4 Biofilter/Acid Concentrator (95\%) PFD 
BIOFILTER PROCESS CONCENTRATING TO $95 \% \mathrm{H}_{2} \mathrm{SO}_{4}$ - ECONOMIC EVALUATION

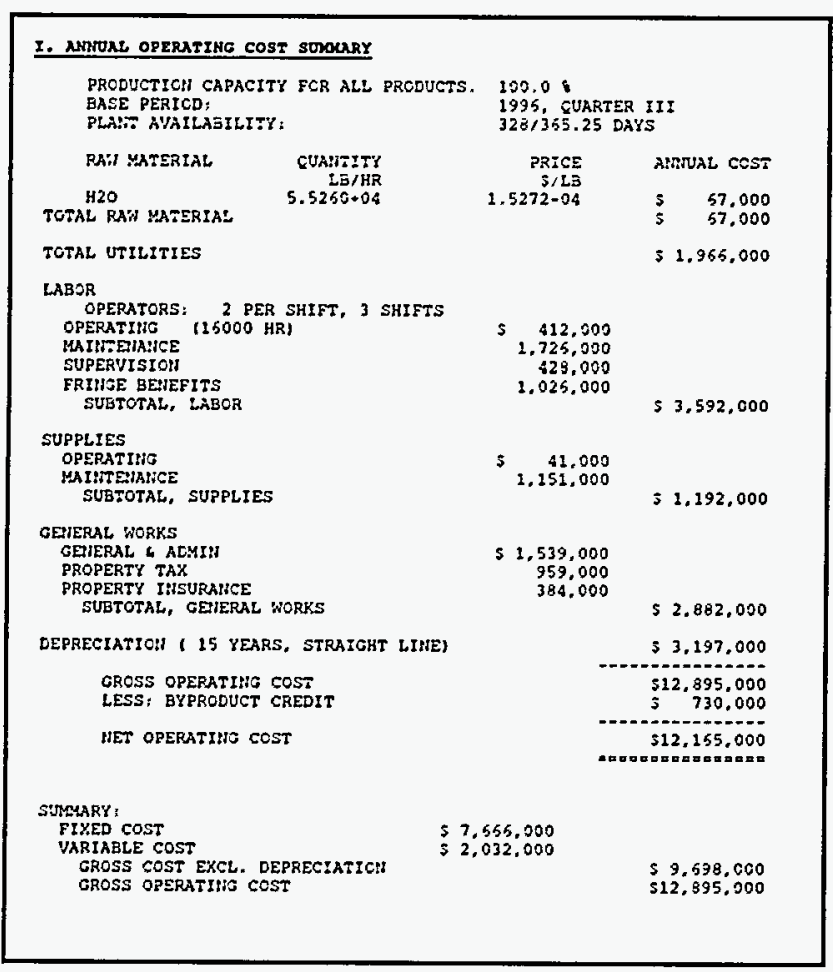

III. COST BLOCX SECTION

BLCEK, APUMP MODEL: PUMP

$$
\cdots \text { imput data } \cdots
$$

IUMBER OP STAUDBYS

PUMP TYPE

MUT STEEO

2-STAGE VERTICAL SPLIT
3550
3.70
3.96 $\quad$ REY

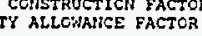

$$
\text { -.. asscerated uellities ... }
$$

USILITY ID FOR ELECTRICITY

CALCULATED RATE OF CONSUYFTION POMER
$2.5175 \mathrm{kN}$

$$
\text { ... FLCUNSHEET REFERENCE DATa ... }
$$

BLCck to

LIQUID VOLUMETRIC FLON

LIGUID DEISITY

OUTLTT PRESSURE

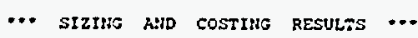

CALCULATED TUMMER OF PUTYPS

VOLUMETRIC FLCN PER PLMP

PCHER RECUERED PER PLMP

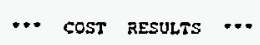

$\begin{array}{lrr} & \text { PER PIECE } & \text { TOTAL } \\ \text { CARBE:I STEEL COST } & 32,000 & 53.700 \\ \text { PURCHASED COST } & 57,300 & 314,500\end{array}$

\begin{tabular}{|c|c|c|c|c|}
\hline \multicolumn{5}{|c|}{$\begin{array}{l}\text { II. PROCESS UNIT DLRECT COST SUMEQRY } \\
\text { CCMPLET:ON: } 1995, \text { QUARTER II } \\
\text { LOCATICN: DANILLE }\end{array}$} \\
\hline cost stcek ID & APUMP & BIosox & ENOSTER & COND1 \\
\hline $\begin{array}{l}\text { CUANTITY } \\
\text { STANDBY } \\
\text { CARBON STEEL COST } \\
\text { PURCHASED COST }\end{array}$ & $\begin{array}{r}1 \\
1 \\
5 \quad 3.900 \\
14.600\end{array}$ & $\begin{array}{r}109 \\
0 \\
51.012 .900 \\
1.012 .900\end{array}$ & $\begin{array}{r}55 \\
5 \\
5182,200 \\
5191,200\end{array}$ & $\begin{array}{r}2 \\
0 \\
\leqslant 59.909 \\
559.900\end{array}$ \\
\hline COST BLOCK ID & CCND2 & $\operatorname{COR} 23$ & DPUMP & DTak \\
\hline $\begin{array}{l}\text { CUARTITY } \\
\text { STAVDYY } \\
\text { CARBOH SIEEL COST } \\
\text { PURCHASED COST }\end{array}$ & $\begin{array}{r}1 \\
5 \\
5 \\
5.200 \\
5.200\end{array}$ & $\begin{array}{r}1 \\
\$ 5 \\
\$ 5.200 \\
5.200\end{array}$ & $\begin{array}{r}1 \\
1 \\
37.500 \\
37.500\end{array}$ & $\begin{array}{r}1 \\
\$ \\
\$ 59,800 \\
559.300\end{array}$ \\
\hline Cost atock id & EVAP1 & EVAP2 & ENAP3 & FLTR \\
\hline $\begin{array}{l}\text { QUAVTITY } \\
\text { STARIEBY } \\
\text { CARBON STEEL COST } \\
\text { PURCHASED CCST }\end{array}$ & $\begin{array}{r}1 \\
\$ \quad 402,800 \\
\$ \\
\$ 2,416,500\end{array}$ & 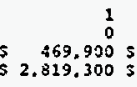 & $\begin{array}{r}1 \\
255.100 \\
3.530 .500\end{array}$ & $\begin{array}{r}1 \\
=35.300 \\
\leqslant 35.320\end{array}$ \\
\hline COST BLOCK ID & HEATI & HEAT2 & HEAT3 & INJECTI \\
\hline $\begin{array}{l}\text { QUANTITY } \\
\text { STARDBY } \\
\text { CARBEN STEEL COST } \\
\text { PURCHASED COST }\end{array}$ & $\begin{array}{r}3 \\
5 \quad 51,100 \\
5 \quad 61,100\end{array}$ & $\begin{array}{r}1 \\
5 \quad 58,600 \\
558,600\end{array}$ & $\begin{array}{r}1 \\
57.500 \\
57.500\end{array}$ & $\begin{array}{r}1 \\
\$ \$ .400 \\
\$ 5.400\end{array}$ \\
\hline COST BLOCK ID & INJECT 2 & PTwK & RPUMP & WPUMP \\
\hline $\begin{array}{l}\text { QUARTITY } \\
\text { STAUDBY } \\
\text { CARBEA STEEL COST } \\
\text { PURCHASED COST }\end{array}$ & 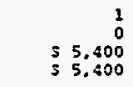 & $\begin{array}{r}1 \\
1 \\
5 \quad 35.500 \\
\$ \\
236.200\end{array}$ & $\begin{array}{r}2 \\
1 \\
555.600 \\
557.000\end{array}$ & $\begin{array}{r}1 \\
53.900 \\
3.900\end{array}$ \\
\hline TOTAL EQUTPMETT COST & $s$ & 8.593 .800 & & \\
\hline TCTAL INVESTMERT & & 48.910 .000 & & \\
\hline
\end{tabular}

BLCCX: BIOBOX MODEL: USER

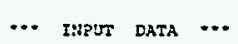

NUYSER OF PEECES OF EQUI PMET
PEAK CAPACITY ALLONAWCE FACTOR 105
1.06

$$
\text { ... user supplied cost ... }
$$

ADJUSTED COST

YEAR OF COST

INDEX TYPE

$$
\begin{array}{r}
59.000 \\
\text { MAY } \\
1994 \\
\text { EQUI PMETT }
\end{array}
$$

... SIzING AND COSTING RESULTS ...

-.. COST Resuets $\cdots$

$\begin{array}{lrr} & \text { PER PIECE } & \text { TOTAL } \\ \text { CARBON STEEL COST } & 59.700 & \$ 1.012 .900\end{array}$

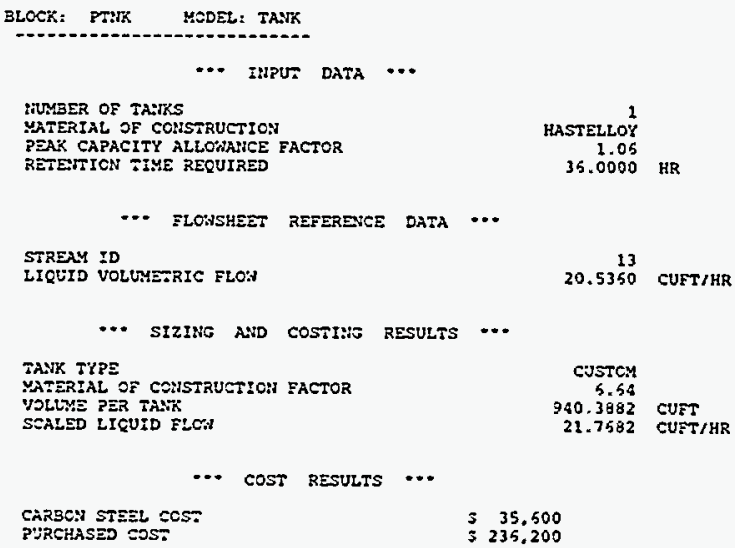

20.5350 CUFT/HR

HASTELLO:

35.0000 
BIOFILTER PROCESS CONCENTRATING TO $95 \% \mathrm{H}_{2} \mathrm{SO}_{4}$ - ECONOMIC EVALUATION

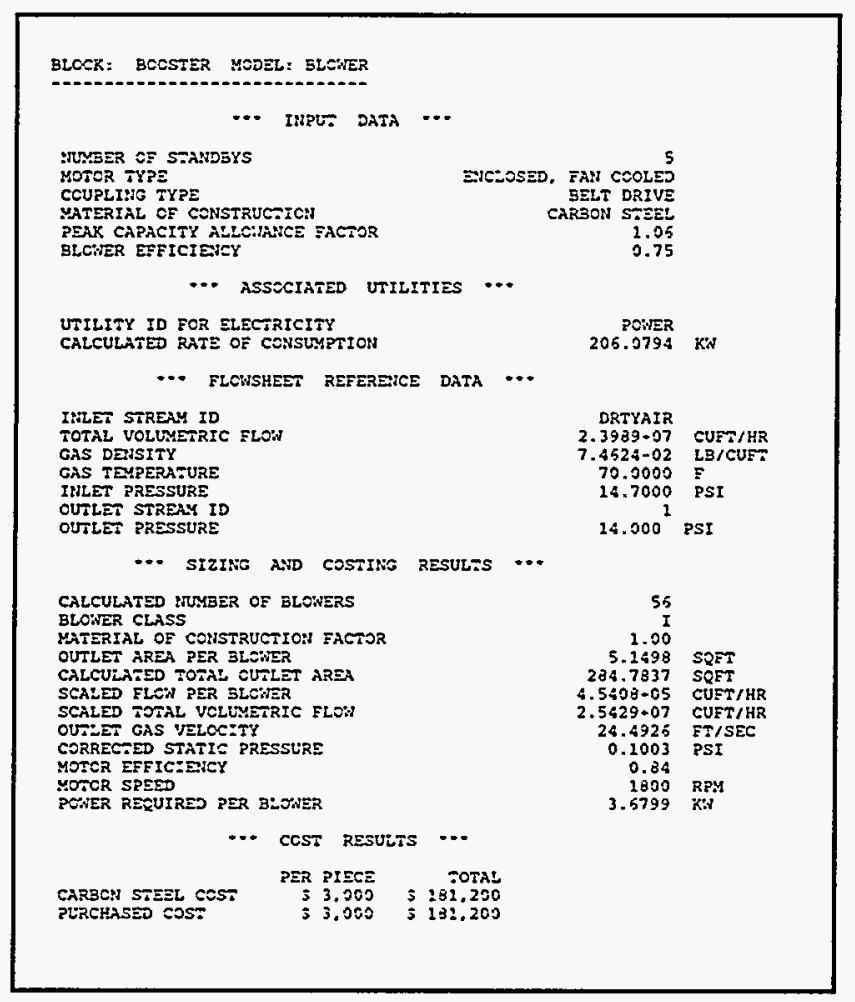

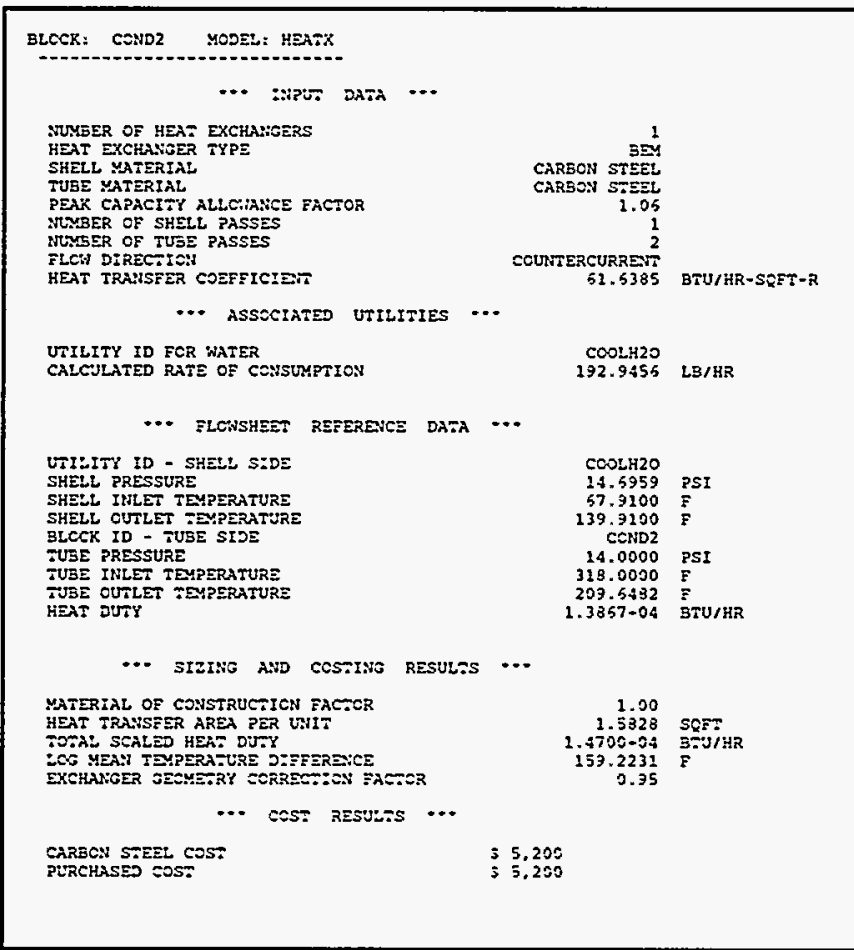

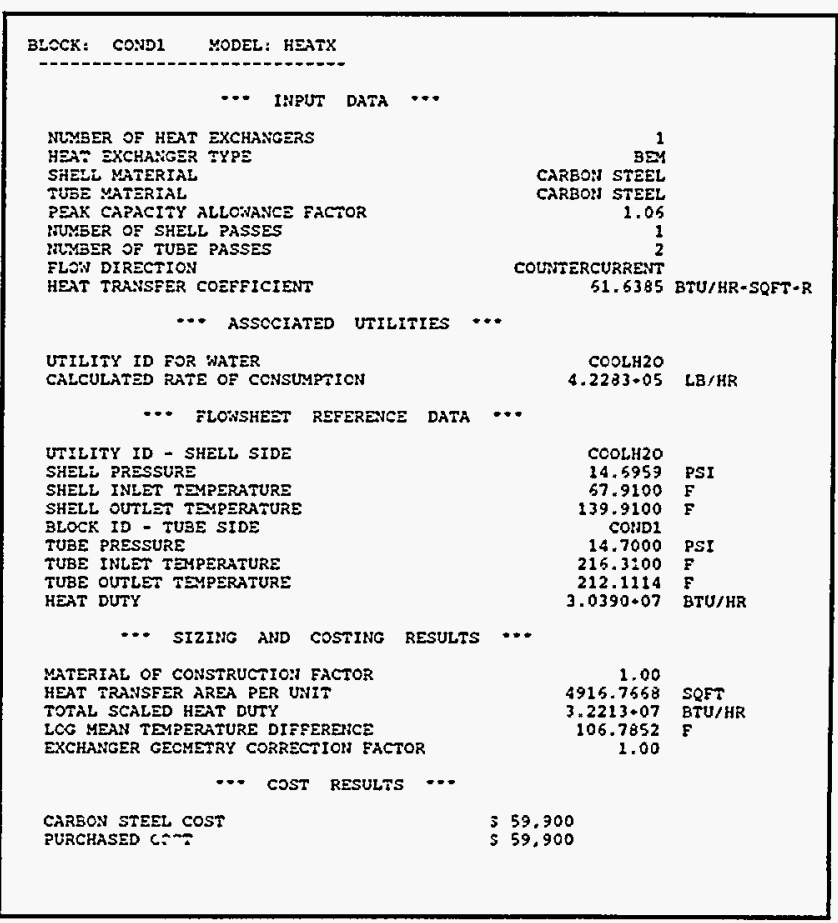


BIOFILTER PROCESS CONCENTRATING TO $95 \% \mathrm{H}_{2} \mathrm{SO}_{4}$ - ECONOMIC EVALUATION

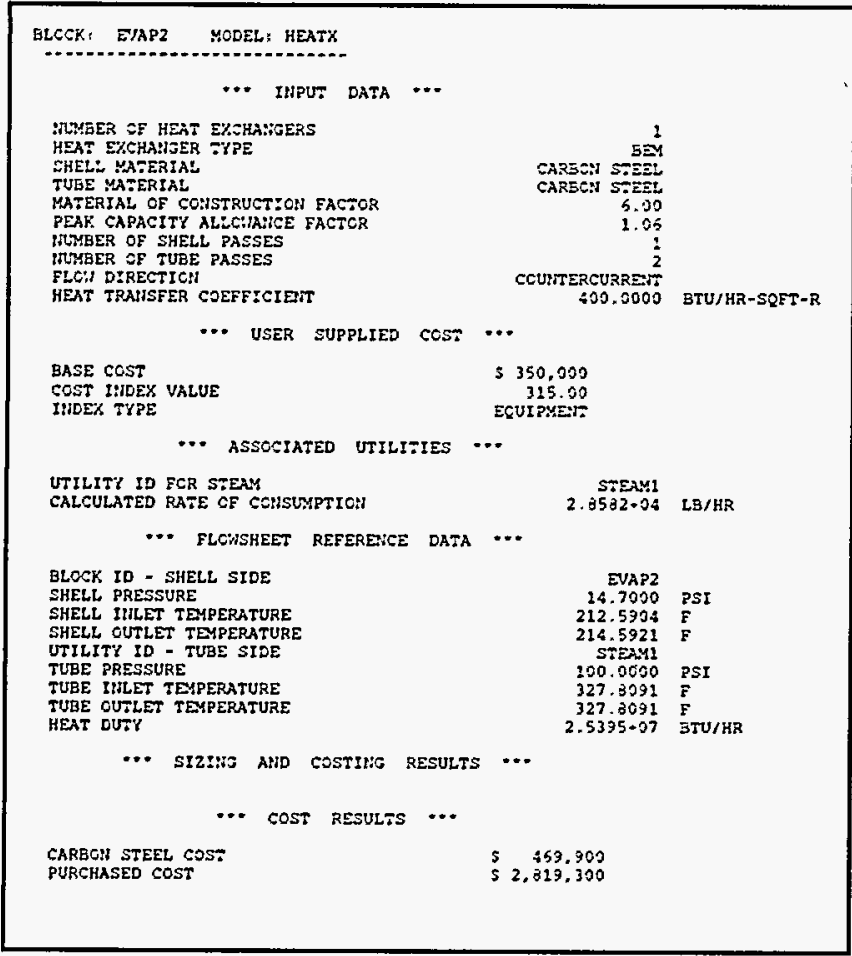

BLCCY: EVAP1 YCDEL: HEATK

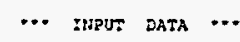

MMAER OF HEAT EXCHAUGERS

SHELL YATERIAL

MATERIAL OF COUSTRUCTICU FACTCR

PEAK CAPACITY ALLOWAMCE FACTOR

ITTMER OF SHELL PASSES

FLCH DIRECTION
HEAT TRAHSEER COEFFICIENT

... USER SUPpLIED COST ...

BASE COST

COST IMDEX VALUE

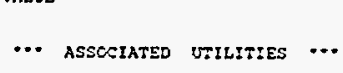

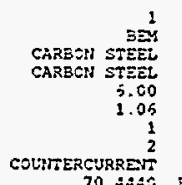$$
\text { COLPTSERCURREM: }
$$

70.4440 $372 / \mathrm{HR}-5 \mathrm{QRE}-\mathrm{R}$

$5 \quad 300.000$

EQUIFNES

UTILITY ID FCR STEAY
CALCULATED RATE OF COUSUMPTICN

$\underset{3,3454-04 \quad \text { LB/HR }}{\text { STEAMI }}$

-. ELCNSHEET REFEREICE DATA ...

ELCCK. ID - SHELL STDE

SHELL PRESSURE

SHELL CUTLET TEYPERATURE

UTILITY ID - TUBE SIDE

TUEE PRESSURE

TUBE IMLET TEYPERATURE

TUEE GUTL

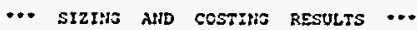

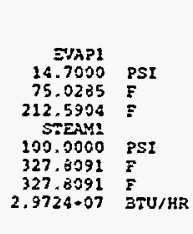

$$
\text { ... COST RESHLES } \cdots
$$

CAREON STEEL CEST

$=\begin{array}{r}402.300 \\ \$ 2 . \$ 15.500\end{array}$

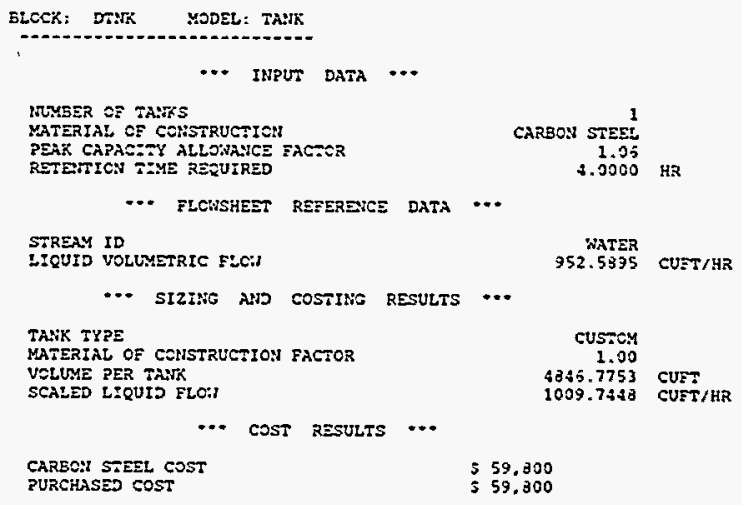

ELCCK; DTNK MODEL: TAMK

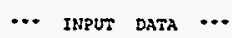

MMEER OE TAMTS

MTISTAL CE COHSTRUCtIEn

PEAR CAPAC:TY ALLONANEE FACSER

-.. Flchisheat Refergeves data ...

CARBON STEEL

4. 1.3060 HR

STREAM ID

WATER
952.5395 CUET/HR

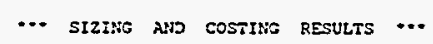

TANK TYPE
MATERIAL OF COHSTRUCTION FACTCR

VELUME PER TANK
SCALED LIQUID FLO:

952.

$$
\text { ... cost results … }
$$

$\begin{array}{lr}\text { CAREOK STEEL COST } & 559.300 \\ \text { PURCHASES COST } & \$ 59.300\end{array}$

Custo.
1.00

$\begin{array}{ll}4345.7753 & \text { CUFT } \\ 1009.7440 & \text { CUFT/HR }\end{array}$

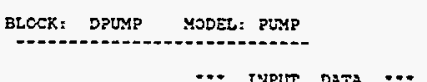

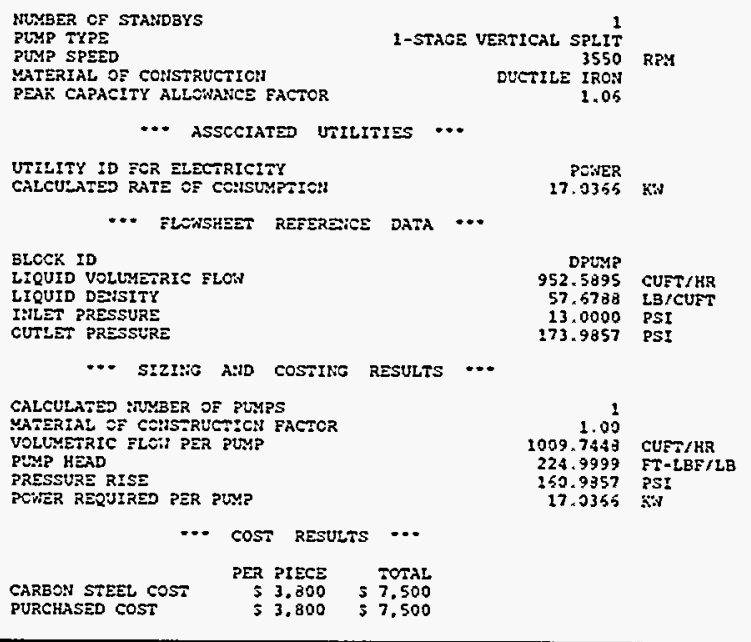

BLOCK: MNJECT2 MODEL: HEATX

-. input jata $\cdots$

ITORER OF HEAT EXCHAHGERS
MEAT EXCHAHGER TYPE

SHELL YATERIAL

FEAE YATERIAL

MTUAER OF SHELL PASSES

NNMMER OF TUBE PASSES

FLCN DIRECTIOI cozfrictert ... user supplied cost ...

ADJUSTED COST YMAR OE COST
INDEX TYRE

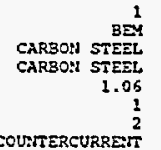
COUITERCURREATT
79.2495 BTU/HR-SQFT-R 55,000
1984
Equreysari

*. stzring ang costirg results $\cdots$

MATERIAL OF COASTRUCTICN FACTOR 1.00 .. cost results ...

CARSON STEEL COST PURCHASED COST 
BIOFILTER PROCESS CONCENTRATING TO $95 \% \mathrm{H}_{2} \mathrm{SO}_{4}$ - ECONOMIC EVALUATION

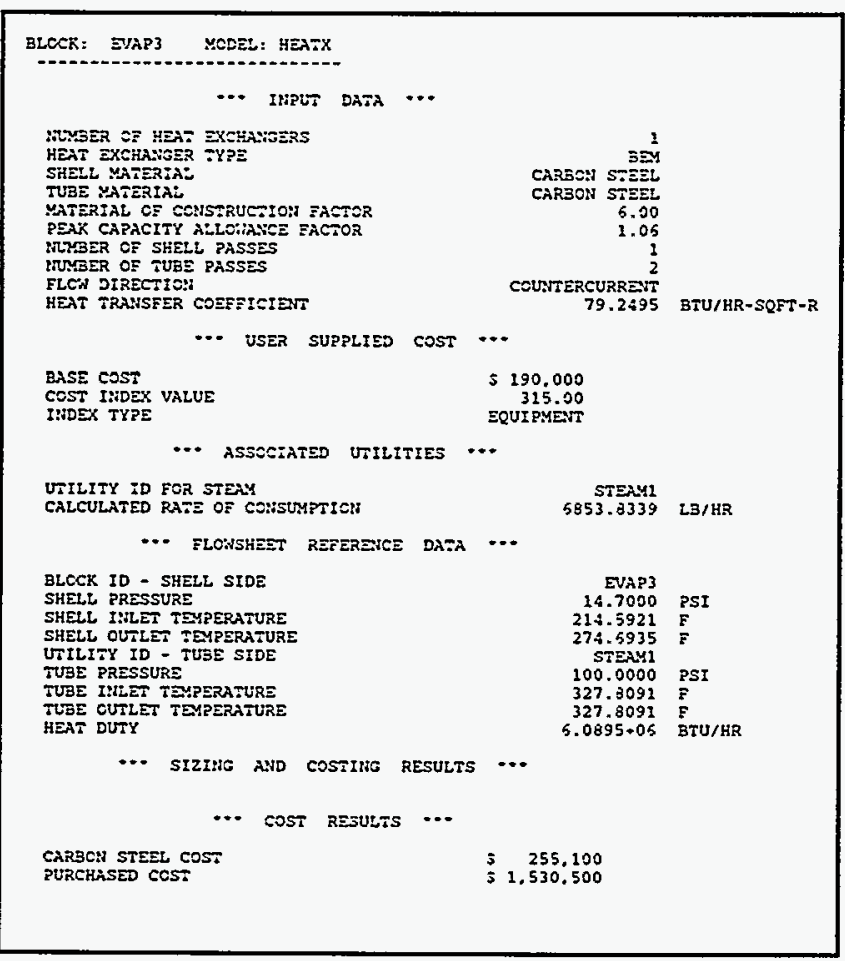

\begin{tabular}{|c|c|c|}
\hline$\cdots$ INPUT DATA $\cdots$ & & \\
\hline 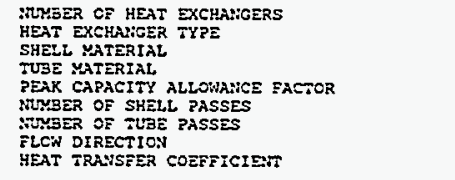 & $\begin{array}{r}\text { SES } \\
\text { CARBON STEEL } \\
\text { GARBON STEEL } \\
1.05 \\
1 \\
2 \\
\text { COURTERCURRERT } \\
17.5110\end{array}$ & $\mathrm{STU} / \mathrm{HR}-\mathrm{SQFT}-\mathrm{R}$ \\
\hline$\cdots$ ASSCCIATED UIILITIES & $\cdots$ & \\
\hline $\begin{array}{l}\text { UTILITY IO FOR WATER } \\
\text { CALCULATED RATE OE CONSUMPTION }\end{array}$ & $\begin{array}{r}\text { COOLH2O } \\
1.2327-05\end{array}$ & LB/HR \\
\hline - ELCHSHEST REFERENCE DATA & $\cdots$ & \\
\hline 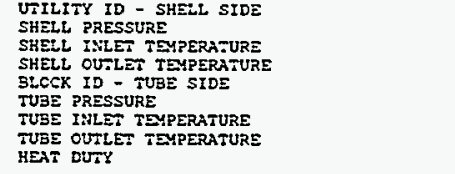 & $\begin{array}{r}\text { COOLH20 } \\
14.5959 \\
57.9100 \\
139.9100 \\
45911 \\
14.7030 \\
212.5924 \\
212.7827 \\
8.3524 .05\end{array}$ & $\begin{array}{l}\text { PSI } \\
E \\
F \\
\text { PSI } \\
\text { F } \\
\text { BTU/HR }\end{array}$ \\
\hline W. SIZFNG AND COSTING RESULTS & $\cdots$ & \\
\hline 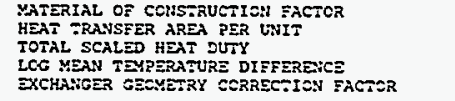 & $\begin{array}{r}: .09 \\
5090.9958 \\
9.3835 .05 \\
104.5593 \\
: .00\end{array}$ & $\begin{array}{l}\text { SQFT } \\
\text { BTU/HR } \\
\text { F }\end{array}$ \\
\hline$\cdots$ ess restifas $\cdots$ & & \\
\hline $\begin{array}{l}\text { CARSE: STEES EST } \\
\text { PURCHASED IOST }\end{array}$ & $\begin{array}{l}351,100 \\
351,100\end{array}$ & \\
\hline
\end{tabular}

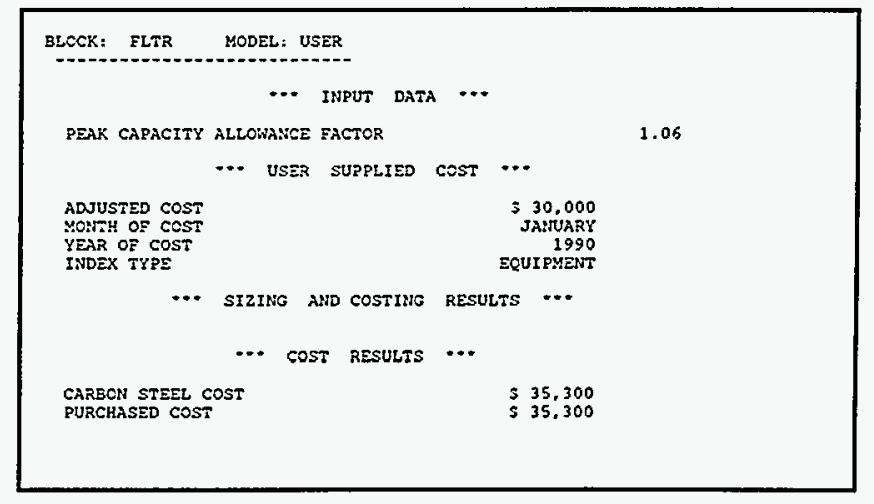

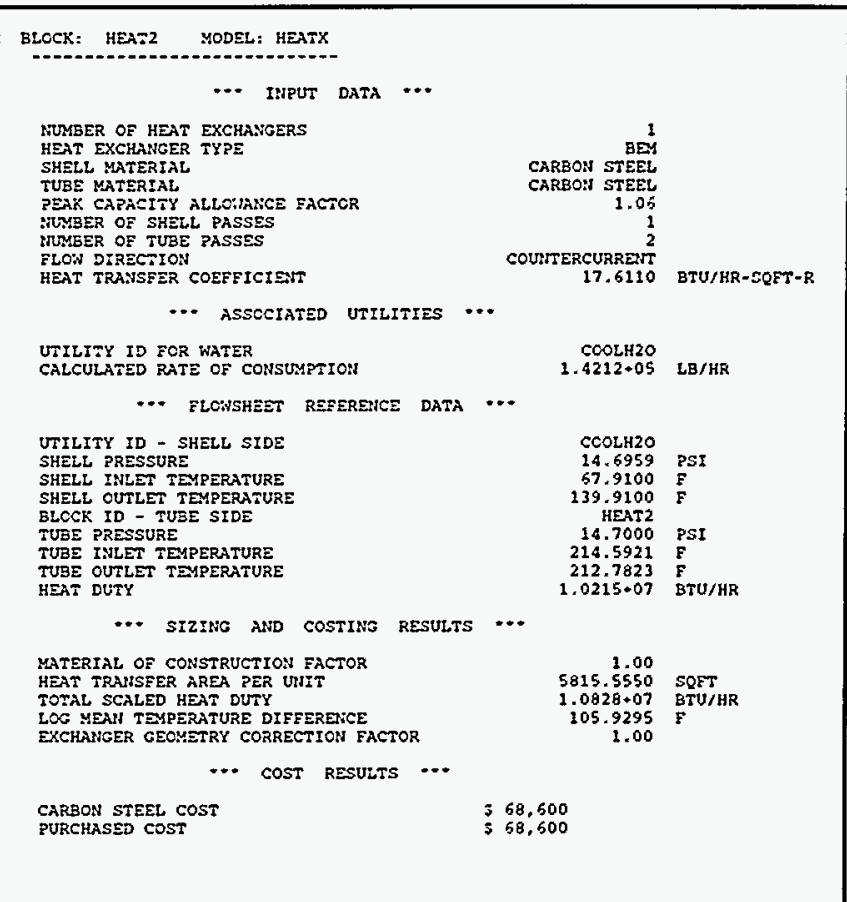

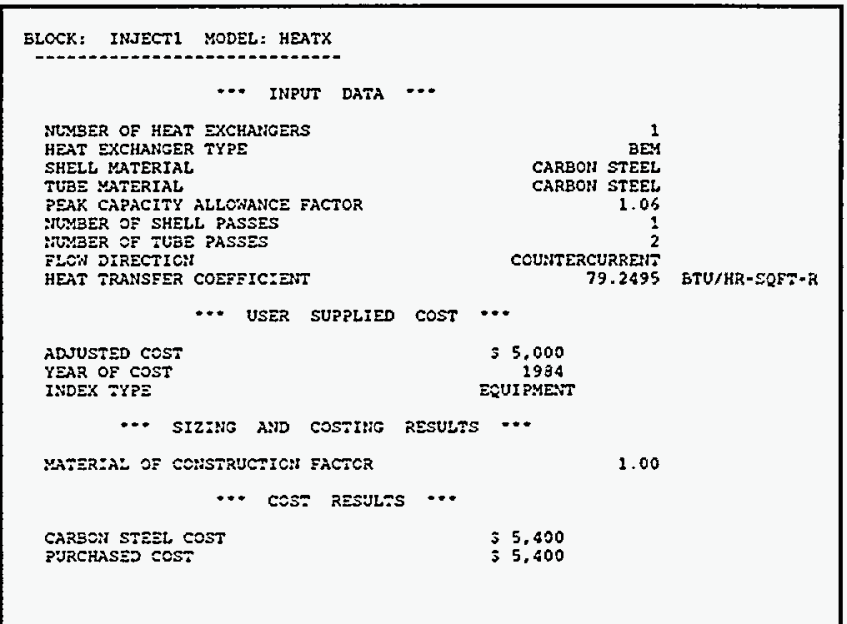


BIOFILTER PROCESS CONCENTRATING TO $95 \% \mathrm{H}_{2} \mathrm{SO}_{4}$ - ECONOMIC EVALUATION
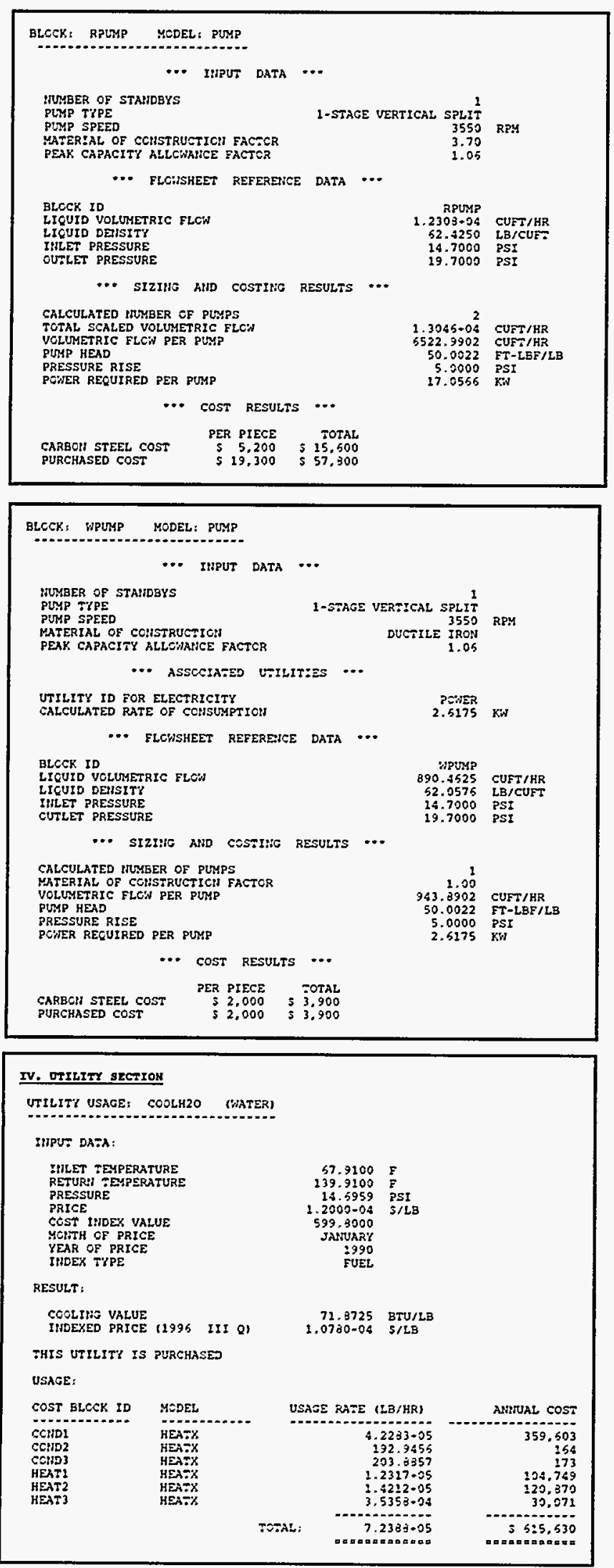

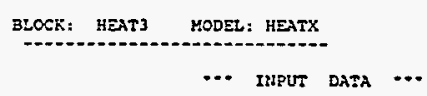

IUNSER OF HEAT EXCHANGERS

HEAT EXCHANGER TYPE

TTEE YATERIAL

PEAK GAPACITY ALECIARCE FACTCR

UUMBER OF SHELL PASSES

TLUMEER OF TUBE PASSES

FLCA DIRECTICH ... asscciated utruities ...

UTILITY ID FOR WATER
CALCULATED RATE OF CONSUXPTIOU

$$
\text { .. FLonsheEt REference data ... }
$$

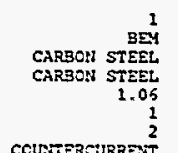

CCURTEREURRETT

100.0000 BTU/HR-SOET-R

CCOLH2O
$3.5358+04 \quad$ LB/HR

UTILITY ID - SHELL SIDE

SHELL PRESSURE

SHELL INLET TEYPERATURE

SHELL OUTLET TEMPERATURE

TUBE PRESSURE

TUBE OUTLET TIMPERATURS

HEAT DUTY

$$
\text { *. SIzENo AND costins RESULtS } \cdots
$$

MATERIAL OE CONSTRUCTION FACTOR

TOTAL SCALED HEAT DUTY

LOG MEAH TEMPERATURE DIFFERENCE

EXCHANGER GEOMETRY CORRECTION EACTOR

$$
\text { ... COST REsULTS ... }
$$

$\begin{array}{ll}\text { CARSON STEEL COST } & \$ 7.500 \\ \text { PURCHASES COST } & 57.500\end{array}$

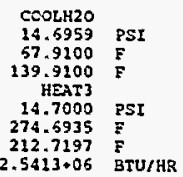

2.5413 .05 BTU/HR

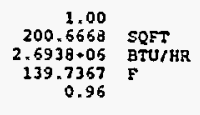

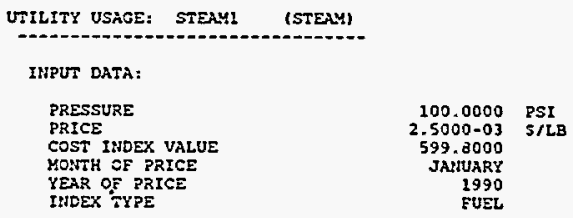

RESULT: $\begin{array}{llrl}\text { HEAT:HS VALUE } & & \text { B98.4353 } & \text { BTU/LS } \\ \text { IMDEXED PRICE (1995 III Q) } & 2.2458-03 & \text { S/LB } \\ \text { INLET TEYPERATURE } & & 327.8091 & \mathrm{~F}\end{array}$ $\begin{array}{lll}\text { TNLET TZUPERATURE } & 327.8091 & F \\ \text { REIURN TEYPERATURE } & 327.8091 & \mathbf{E}\end{array}$

THIS UTILITY IS PURCHASED

USAGE:

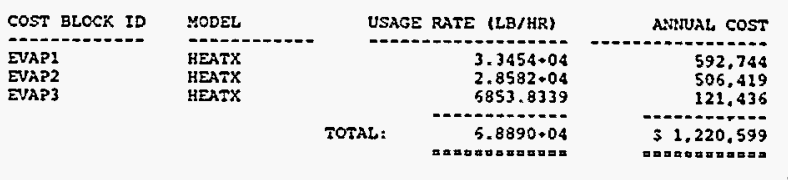

UT:LITY USAGE: PONER (ELECTRICITY)

:NPUT פATA:

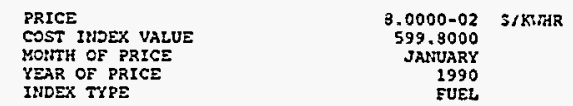

RESUL::

SNDEXED PRICE 12995 III Q $) \quad 3,1365-02 \quad$ 3/K:HR THIS UTILITY IS PURCHASED

USAGE:

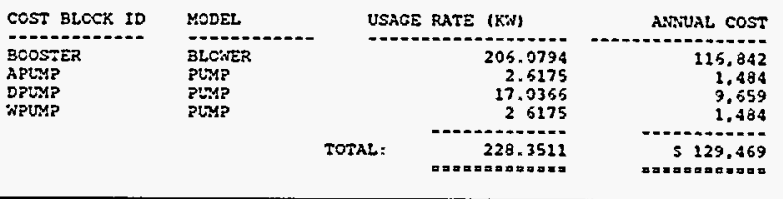




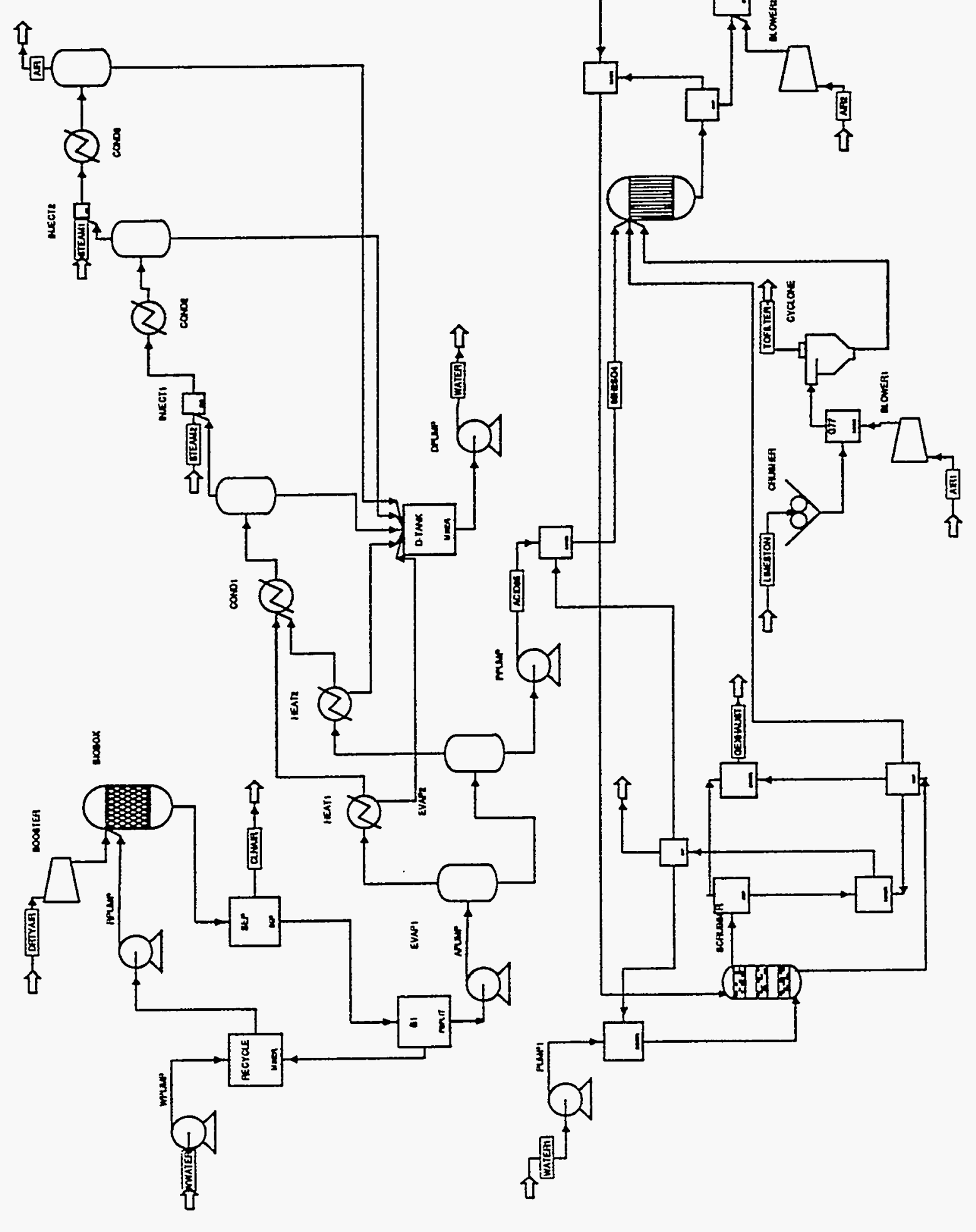

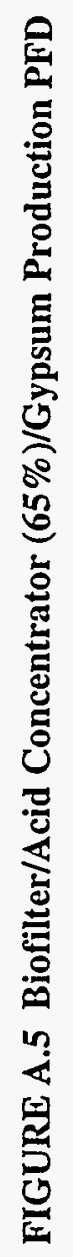


BIOFILTER PROCESS PRODUCING GYPSUM - ECONOMIC EVALUATION

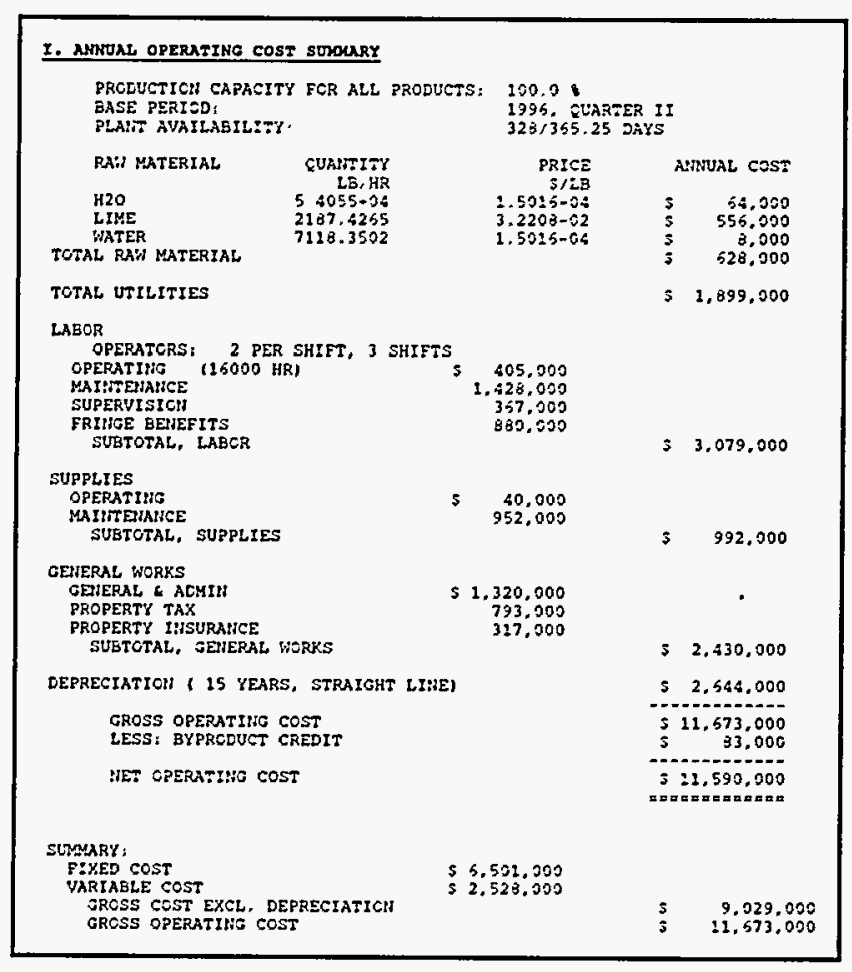

HI.CONTHIOCKSECTON

BLOCK ACIDTNK MODEL TANK

... INPUT Data ...

NUMBER OIFTANKS

MATERIAL OF CINSTRLCTION I'CARBON STEEL

PEARCAPACITY ALWOWANCE FACTOR
TIITAL VOLUME
361.26\% CUFT

... SIZING AND COSTING RESULTS ...

TANK TYPE

CUSTUM

MATERIAL.OFCONSTRUCTUN FACTOR
VOLUME PER TANK
361 26\% CUFT

*. COST RESULTS ...

CARBUN STEEL COST 520.90

PURCHASED COST

BLCCK: BELTI MODEL: USER

$.15 \times$ : 0 GELVEYCR GELT FCR LIMESTONE

PEAK CAPACITY ALLCOAUCE EACTOR

$$
\text { .. user supph:ej cost } \cdots
$$

ADJUSTED CCST

ADJUSTED CCST
GCST INDEX VALUE
HDEX TYRE

... SIz:日勺

$$
\text { -.. cost Rasuges ‥ }
$$

CARSEN STEE: ECS:
PUREHASET COSE

\section{$3: 5.00$}

\begin{tabular}{|c|c|c|c|c|c|}
\hline \multicolumn{6}{|c|}{$\begin{array}{l}\text { COMPLETION 1995, QUARTER II } \\
\text { LOCAIICN: DANVILLE }\end{array}$} \\
\hline $\cos :$ ELCCK ID & APUMP & \multicolumn{2}{|c|}{ Brosox } & BOOSTER & CONDI \\
\hline $\begin{array}{l}\text { QUARITY } \\
\text { STANDSY } \\
\text { CARSON STEEL COST } \\
\text { PURCHASED COST }\end{array}$ & $\begin{array}{r}1 \\
1 \\
5 \quad 3.900 \\
514.500\end{array}$ & 51.007 & $\begin{array}{r}104 \\
0 \\
.200 \\
.200\end{array}$ & $\begin{array}{r}55 \\
5 \\
\$ \\
\$ \\
3180,200 \\
130.200\end{array}$ & $\begin{array}{r}1 \\
59.400 \\
59.400\end{array}$ \\
\hline COST BLCCX ID & $\cos 102$ & & o::03 & DFUMP & DTHK \\
\hline $\begin{array}{l}\text { QUANTITY } \\
\text { STAHDBY } \\
\text { CARBOH STEET COST } \\
\text { PURCHASED COST }\end{array}$ & $\begin{array}{r}1 \\
55 \\
55.100 \\
55100\end{array}$ & $\begin{array}{l} \\
35 \\
5\end{array}$ & $\begin{array}{r}1 \\
.100 \\
.100 \\
\end{array}$ & $\begin{array}{rl} & 1 \\
1 \\
5 \\
5 \\
5 \\
3.90005 & 5\end{array}$ & $\begin{array}{r}1 \\
59.500 \\
59.500\end{array}$ \\
\hline $\operatorname{cosT}$ BLCCK ID & EVAP1 & & VAP2 & FLTR & HEAT: \\
\hline $\begin{array}{l}\text { QUANTITY } \\
\text { STANDBY } \\
\text { CARSN STEEL COST } \\
\text { PURCEASED COST }\end{array}$ & 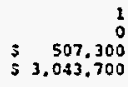 & $\$ 2323$ & $\begin{array}{r}1 \\
.800 \\
.700\end{array}$ & 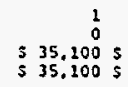 & $\begin{array}{r}1 \\
91 \\
91,100 \\
91,100\end{array}$ \\
\hline COST BLOCK ID & HEAT2 & & JECT & INJECT2 & PTwK \\
\hline $\begin{array}{l}\text { QUANTITY } \\
\text { STAHDBY } \\
\text { CARBON STEEL COST } \\
\text { PURCHASED COST }\end{array}$ & $\begin{array}{r}1 \\
5 \quad 44.200 \\
\$ 44,200\end{array}$ & $\begin{array}{ll} & \\
& \\
5 & 6\end{array}$ & $\begin{array}{r}2 \\
0 \\
700 \\
700\end{array}$ & 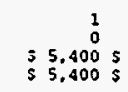 & $\begin{array}{r}1 \\
42.500 \\
42.500\end{array}$ \\
\hline $\begin{array}{l}\text { COST SLECK ID } \\
\text { GUATITY } \\
\text { STAUDBY } \\
\text { CARBON STEEL COST } \\
\text { PURCHASED COST }\end{array}$ & $\begin{array}{r}\text { RPUSP } \\
2 \\
0 \\
510.400 \\
5 \quad 38.300\end{array}$ & $\begin{array}{l}53 . \\
53\end{array}$ & $\begin{array}{r}9049 \\
1 \\
1 \\
900 \\
900\end{array}$ & $\begin{array}{r}\text { SCRUSBSR } \\
1 \\
50 \\
57.200 \\
57.200\end{array}$ & \\
\hline $\cos 5$ SLCCK ID & Acromsk & & ELTI & SELT2 & BIM \\
\hline $\begin{array}{l}\text { QUARTITY } \\
\text { STAMDBY } \\
\text { CARBEH STEEL COST } \\
\text { PURCHASED COST }\end{array}$ & $\begin{array}{r}1 \\
\$ 20,200^{\circ} \\
\$ 20,200\end{array}$ & $\$ 8$. & $\begin{array}{r}1 \\
700 \\
700\end{array}$ & $\begin{array}{r}1 \\
0 \\
\$ \$ 8.7005 \\
\$ 8.7005\end{array}$ & $\begin{array}{r}1 \\
11.800 \\
11.800\end{array}$ \\
\hline $\operatorname{cosT}$ BLOCK ID & BLC:SERI & SLC:JER? & crus & ISHER CYCLONE & \\
\hline $\begin{array}{l}\text { GUATTITY } \\
\text { STAIDSY } \\
\text { CARBOH STEEL COST } \\
\text { PURCHASED COST }\end{array}$ & $\begin{array}{r}1 \\
1 \\
\$ 3.700 \\
3.700\end{array}$ & $\begin{array}{r}1 \\
3 \\
53.700 \\
3.700\end{array}$ & $\begin{array}{ll} & \\
\text { 5 } 28 . & \end{array}$ & $\begin{array}{rr}1 & 1 \\
0 & 0 \\
900 & \$ 2,000 \\
900 & \$ 1,000\end{array}$ & \\
\hline $\cos 5$ BLOCK ID & $D E 2$ & FILTER & ESE & PEIT HOPPER & \\
\hline $\begin{array}{l}\text { QUATTITY } \\
\text { STANOEY } \\
\text { CARBCN STEEL COST } \\
\text { PURCHASED COST }\end{array}$ & $\begin{array}{rl}1 & 1 \\
0 & \\
\$ & 9.9005 \\
3 & 9.9005\end{array}$ & $\begin{array}{r}2 \\
0 \\
57.800 \\
57.800\end{array}$ & & $\begin{array}{rr}1 & 1 \\
0 & \\
200 & \$ 9.950 \\
200 & \$ 9.900\end{array}$ & $\begin{array}{l}1 \\
0 \\
0 \\
0 \\
0\end{array}$ \\
\hline $\operatorname{CosT} B L C C K$ ID & $x-1$ & $\mathrm{M}-2$ & 80 & UMP1 REACTOR & \\
\hline $\begin{array}{l}\text { CUAMTITY } \\
\text { STANDSY } \\
\text { CARECH STEEL COST } \\
\text { PURCHASED COST }\end{array}$ & $\begin{array}{r}2 \\
5 \\
54,000 \\
5,000\end{array}$ & $\begin{array}{r}1 \\
0 \\
34,800 \\
4,200\end{array}$ & & $\begin{array}{rr}1 & \\
0 & 1 \\
.700 & \$ 5.000 \\
.700 & 55.000\end{array}$ & $\begin{array}{l}1 \\
0 \\
0 \\
0\end{array}$ \\
\hline TOTAL EQUIPMEMT COST & 57. & 081.600 & & & \\
\hline TOTAL INVESTMEIT & $\$ 40$. & $.454,000$ & & & \\
\hline
\end{tabular}

$$
\begin{aligned}
& 3,700 \\
& 30,702
\end{aligned}
$$

BLCEK: BELT2 MODEL: USER

O.15 X 10 CONVEYOR BELT EOR GYPSUM

$$
\text { -.- inzUt data } \cdots
$$

PEAK CAPACITY ALLCHANCE FACTOR

$$
\text { ... user supplied cost ... }
$$

COST INDEX VALU
ADJustad cost

THDXX $268 \mathrm{X}$

EQuा8M:5

-.. SIZTRE AND COSTING RESULTS $\cdots$

$\cdots$ COST RESULTS $\cdots$

CARSON STEEL cost

PUREHASET SOST
5.720
3.700 


\section{BIOFILTER PROCESS PRODUCING GYPSUM - ECONOMIC EVALUATION}

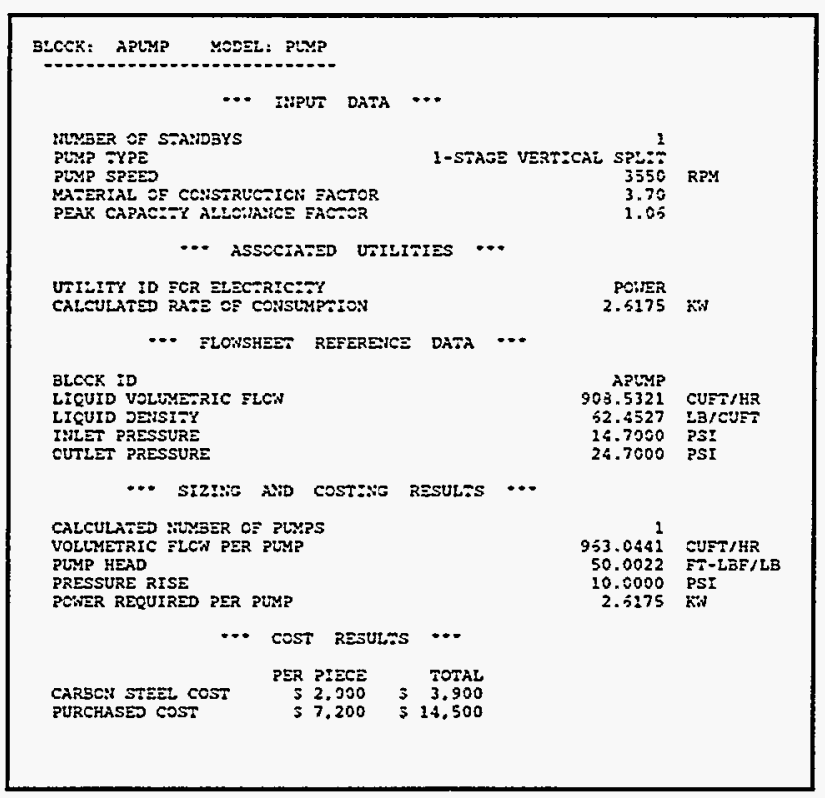

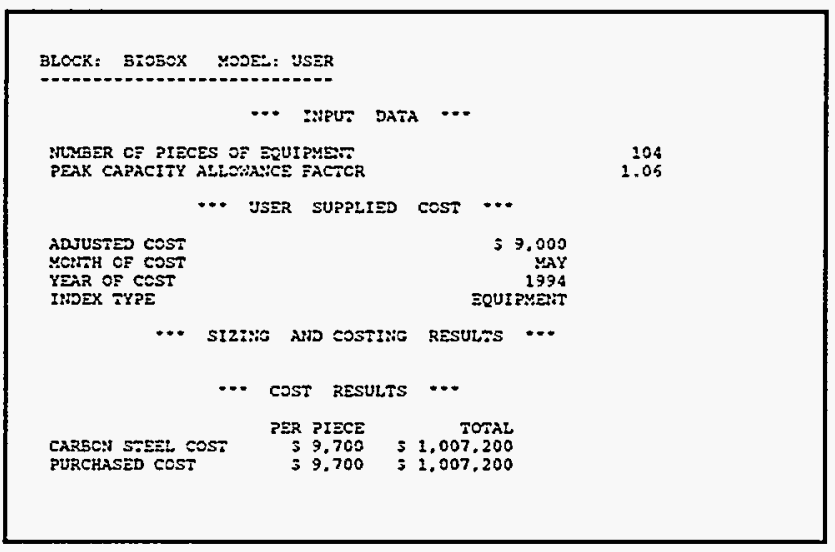

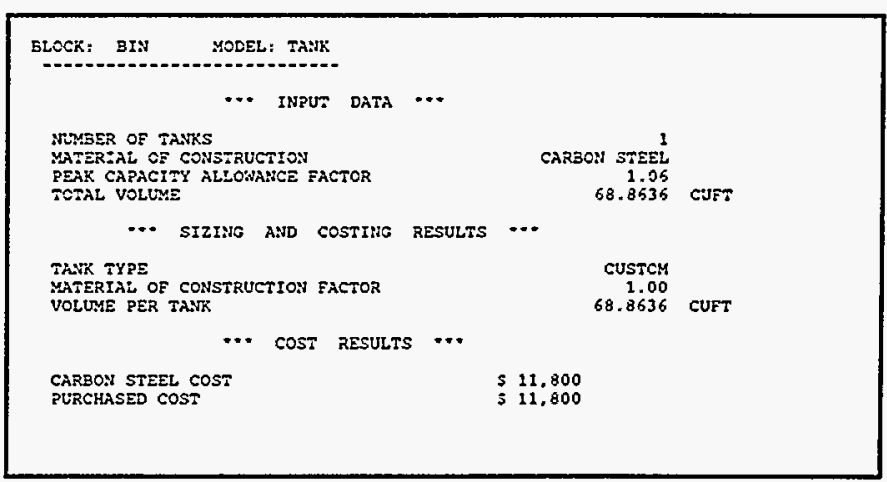

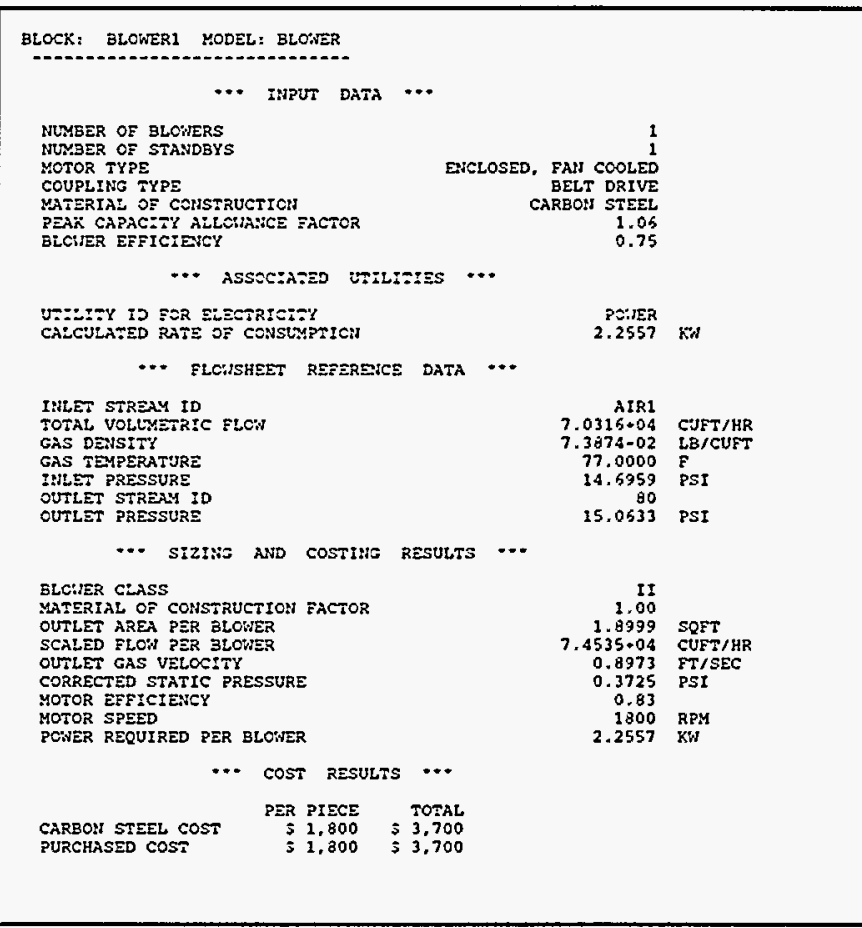

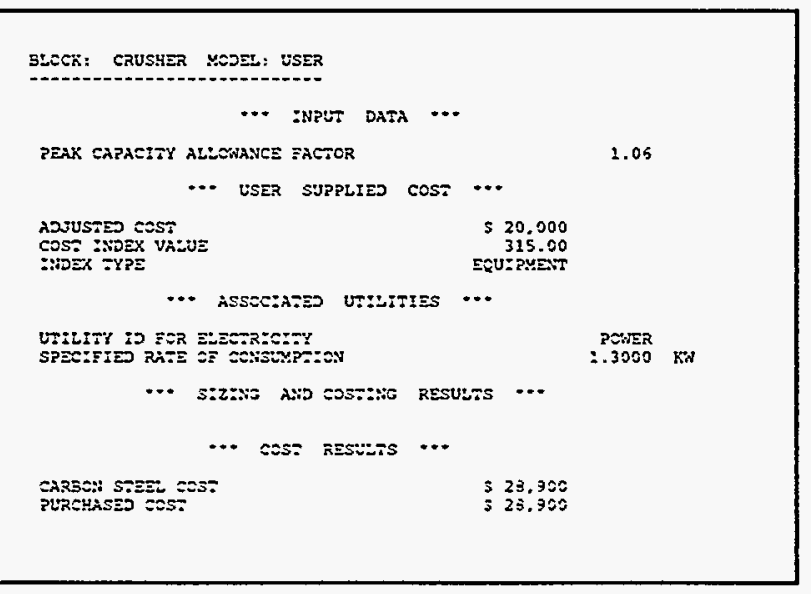

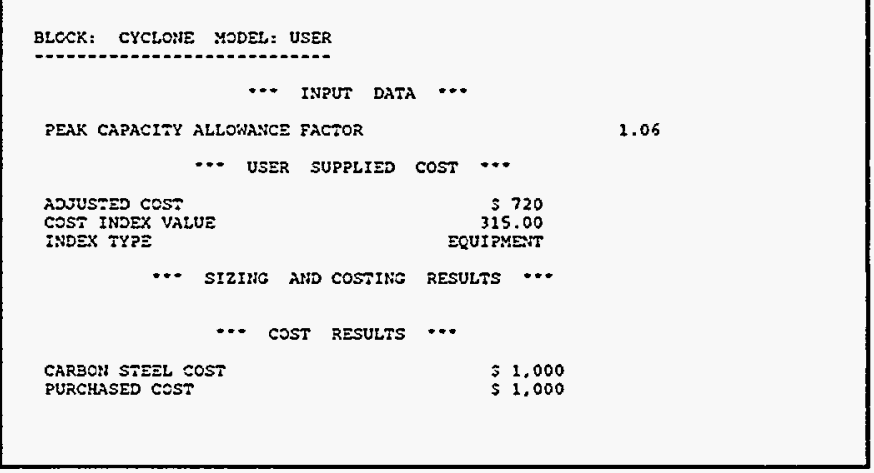


BIOFILTER PROCESS PRODUCING GYPSUM - ECONOMIC EVALUATION

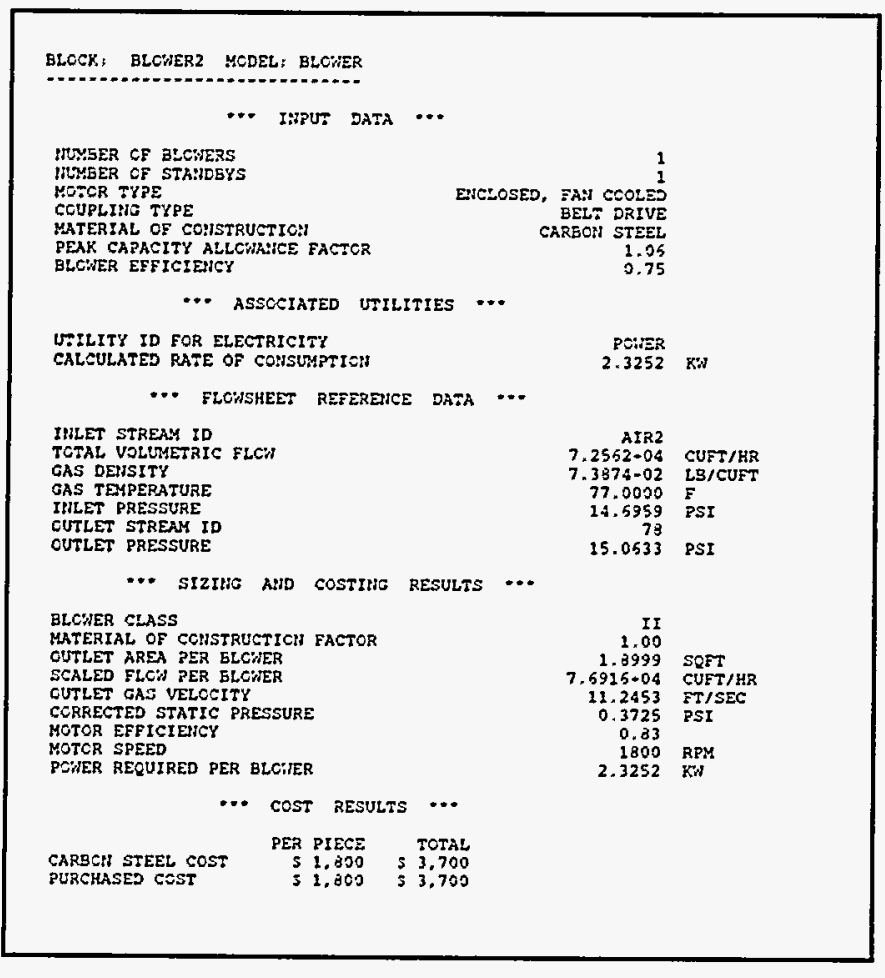

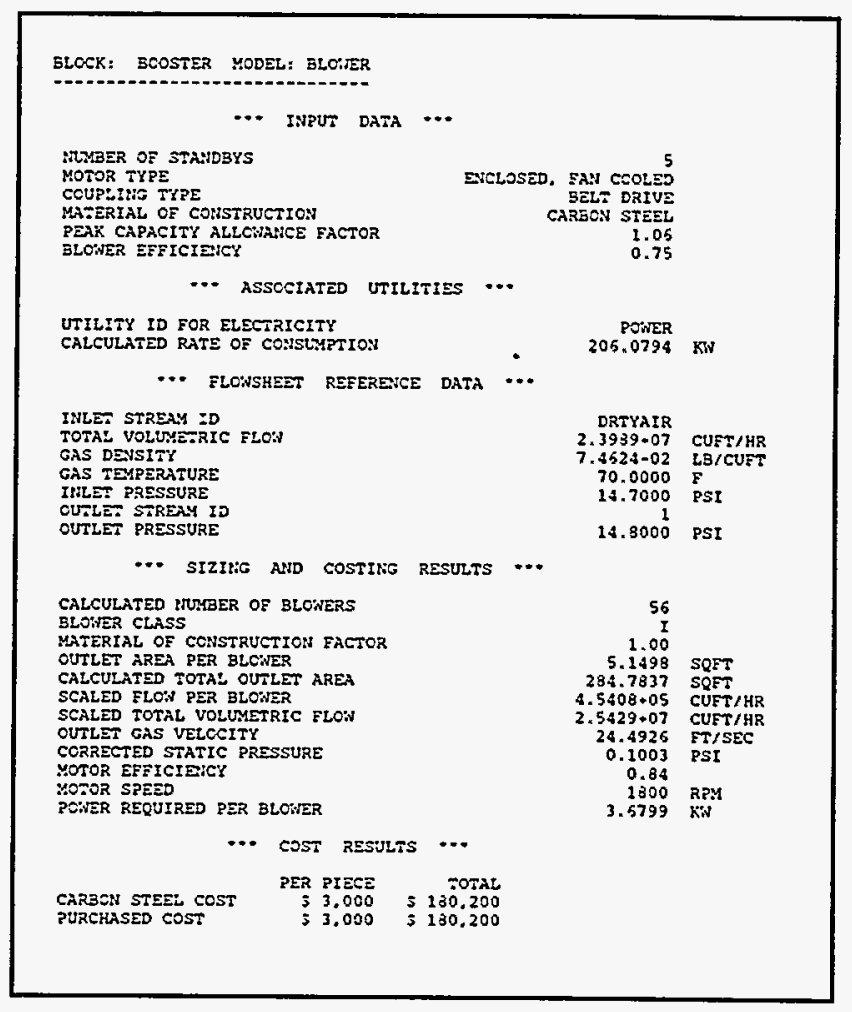

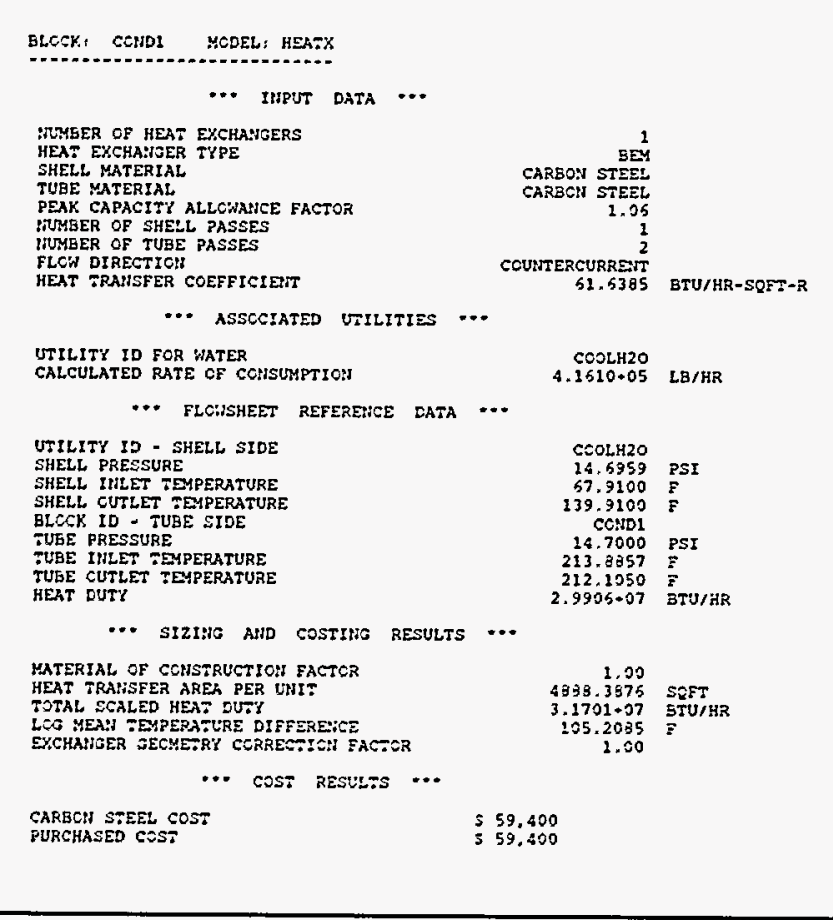

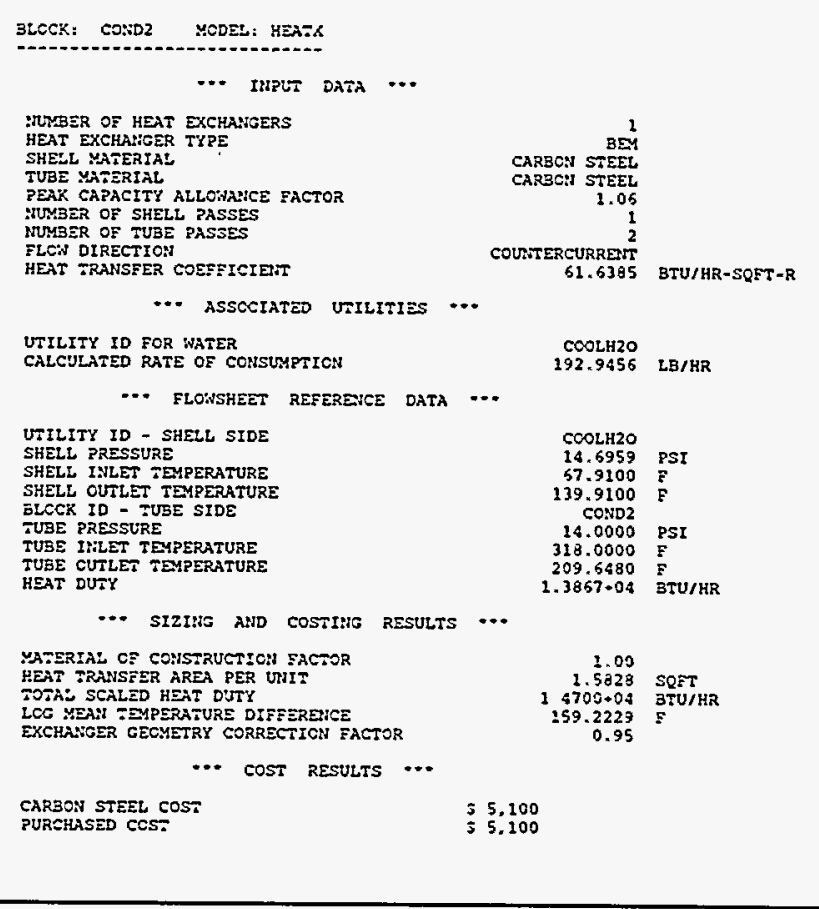


BIOFILTER PROCESS PRODUCING GYPSUM - ECONOMIC EVALUATION
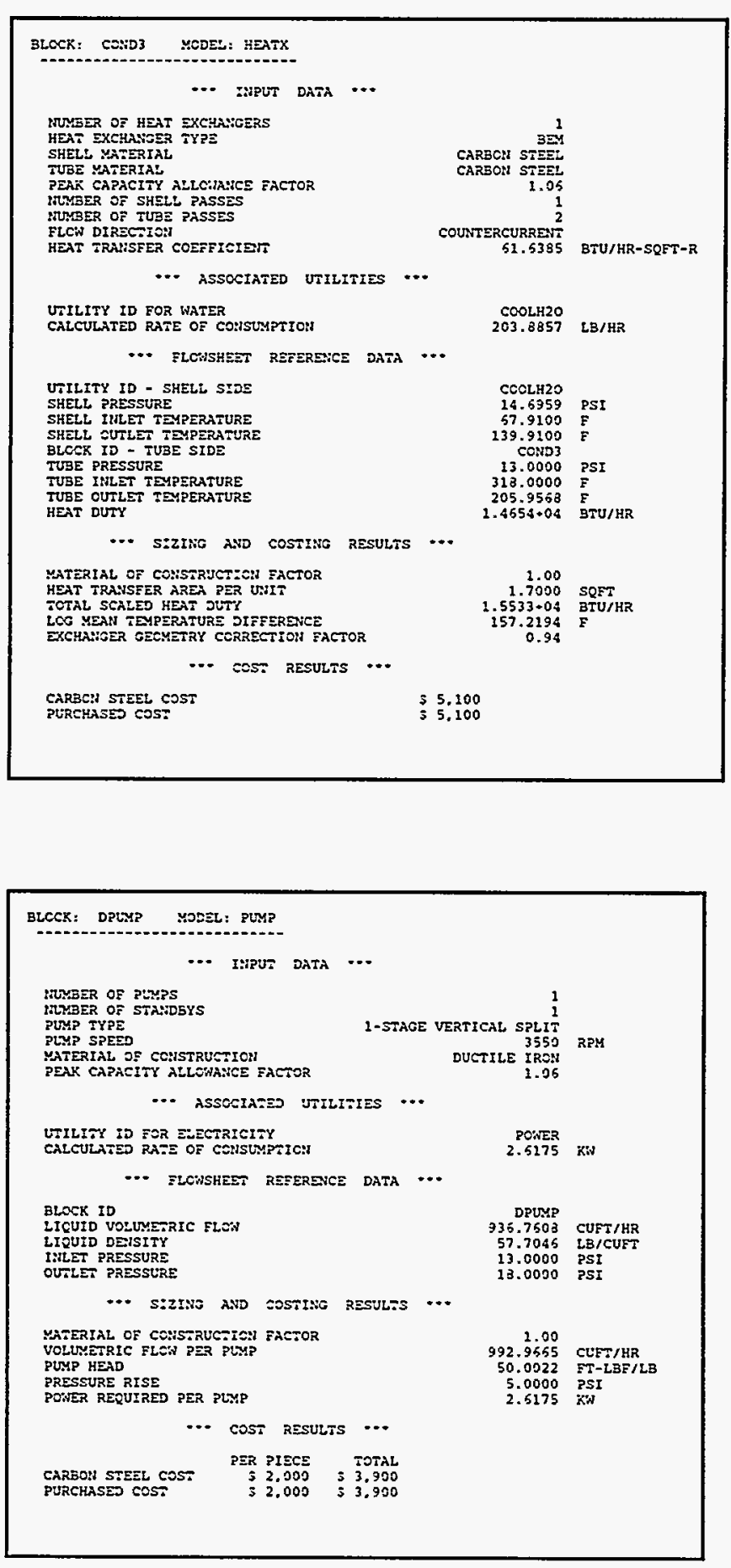

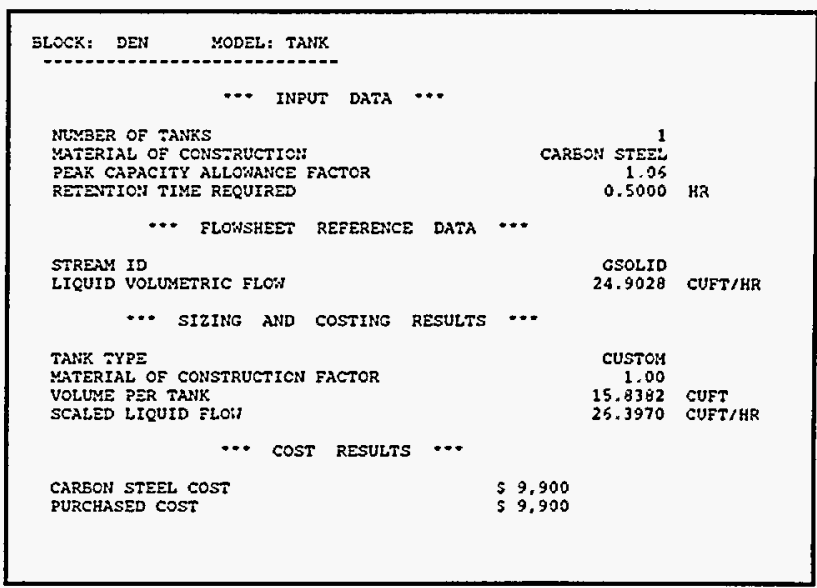

\section{BLCCK: DTIK MODEL: TANK -.. input data $\cdots$ \\ NUMBER OE TAMYS} ZATERTAL oE CONSTRUCTION PEAR CAPACITY ALLONA:ICE FACTOR RETZT:CA TIME REGUZRED -.. TLOUSHEET REFEREICE DATA $\cdots$ STREAM ID LIQUID VOLUMETRIC FLON -.. SIzthe AND COSTINe REsults $\cdots$ TANK TYPE MATERTAL OE CONSTRUCTION FACTOR VOLLME PER FANK
SCALED LIQUTD FLOH 4755.2391 CUFT .. COST RESULTS $\cdots$

SAREON STEEL COST
PURERASED COST

SLOCK: FILTER MODEL: USER
$\cdots$
$\cdots$
$\cdots$


BIOFILTER PROCESS PRODUCING GYPSUM - ECONOMIC EVALUATION

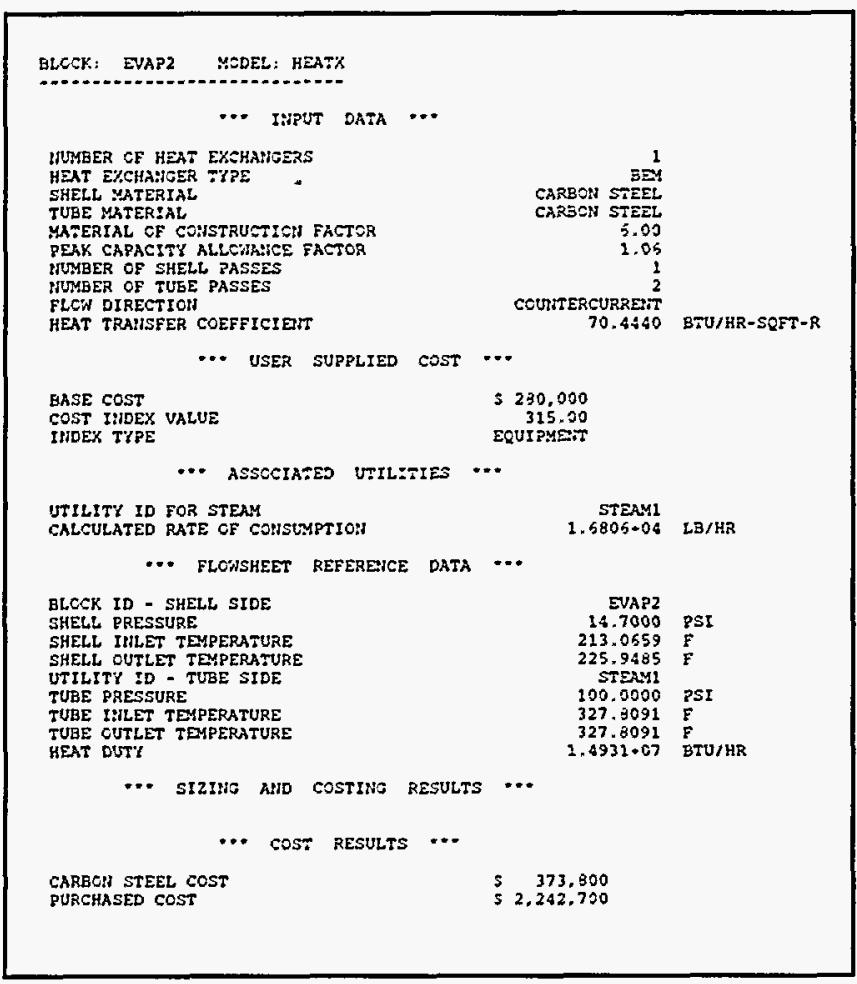

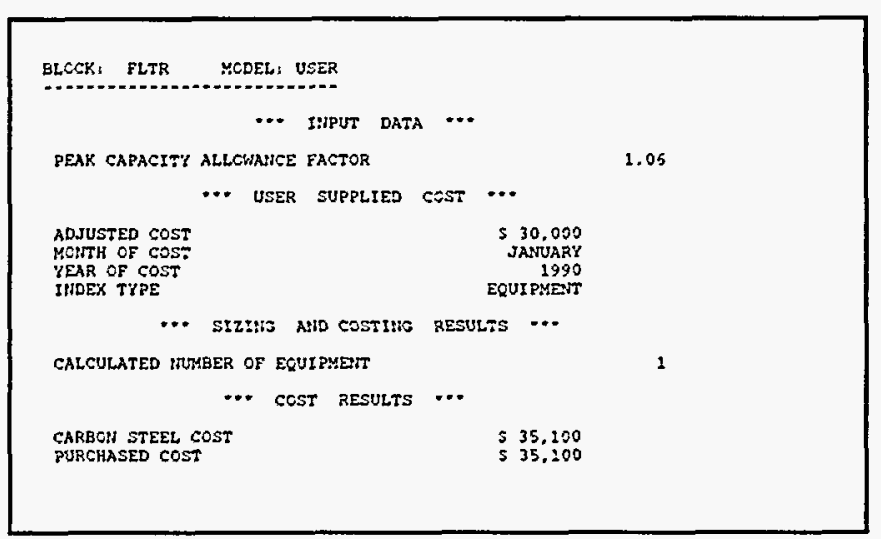

BLCEK: HOPPER MODEL: TAMK

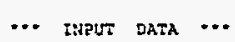

INMBER OF TAMKS

MATERIAL CF CEHSTRUCTICH

PEAK CAPACITY ALLCHANEE FACTOR

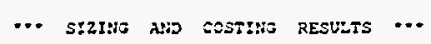

CARECN STEEL 12

13.1.25 cur:

TAIK TYPE

TAIK TYPE
MATERIAL CF CCHSTRUCTICH FACTER
VOLLYE PER TA:K

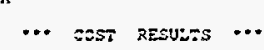

CARSCN STEE: COST
PURCHASED COST $\operatorname{ctstcm}$

$: 3.1370$ SUE

39,900
59,900
BLCCK: SVAP1 MODE: HEATX

$$
\text { -. ingut data } \cdots
$$

MWOER OF HEAT EXCHANGERS

HEAT EXCHANAER TYP

SHELL MATERTAL

MATERIAL OF COHSTRUCTICN FACTOR

PEAK CAPXCITY ALLOAANEE FACTOR

MUMBER OF SHELL PASSES

TLCW DIRECTION

HEAT TRALISFIR COEFFICIENT

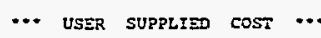

BASE COST

COST ILDEX VALUE

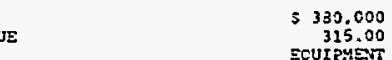

... asscciated utilities ...

TTITITY ID FOR STCOY

GIILITY ID FOR STSAM
CALCULATED RATE OF CONSUMPTIOH

... FLCisheEt REFERENCE DATA ...

BLOCX ID - SHELI SIDE

SHELL PRESSURE

SHELL INLET TEMPERATURE

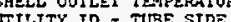

TUBE PRESSURE

TUBE INLET TEMPERATURE

UBE OUTLET TEAPERATURE

... SIzING AND COSTING RESULTS ...

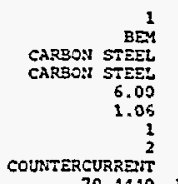

COUNTERCURREIT

STEMM1

$5.1007 .04 \quad 28 / 48$

$\cdots$ COST REsults $\cdots$

CARDON STEEN, COST

5 $\begin{array}{r}507.300 \\ 3.043 .700\end{array}$

CARDON STEEH, COS

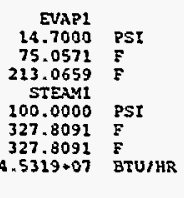

BLOCK: FSPLIT MOLEL: USER

$$
\text { -.. input Data ... }
$$

PEAK CAPACITY ALLCWANCE FACTOR 1.06

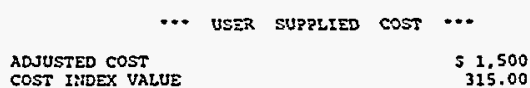

COST IHDEX VALUE
IMDEX TYPE
$\ldots$

... SIZIRG ARD COSTING RESULTS $\ldots$

-.. COST RESUETS $\cdots$

CAREON STEEL COS: $\quad$ \$ 2.200

BLOCK: MHECTI YOOEL: HEATX

-.. InPUT Data $\cdots$

ILMSER OF HEAT EXCHARGERS

HEAT EXCHA:TGER TXPE

SHELL YATERIAL

TUBE YATERIAL CAPACITY ALLOIANCE FACTOR

NUMBER OF SHELL PASSES

TNXSER OE TUBE PASSES

FLCA DIRECACA

2,200

-.. USER SUPPLIED COST -

$\begin{array}{lr}\text { ADUUSTED COST } & \$ 5.000 \\ \text { COSE INEEX VA:UE } & 315.00 \\ \text { INDEX TIPE } & \text { EQUIPMENT }\end{array}$

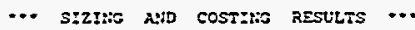

MATEREAL OE CONSERUCTICA FACTOR 1.00

$$
\text { -. cose rastits } \cdots
$$

$\begin{array}{ll}\text { CARSEN SEEEL GEST } & \$ 5.700 \\ \text { PÜREASED COST } & 5.700\end{array}$ 

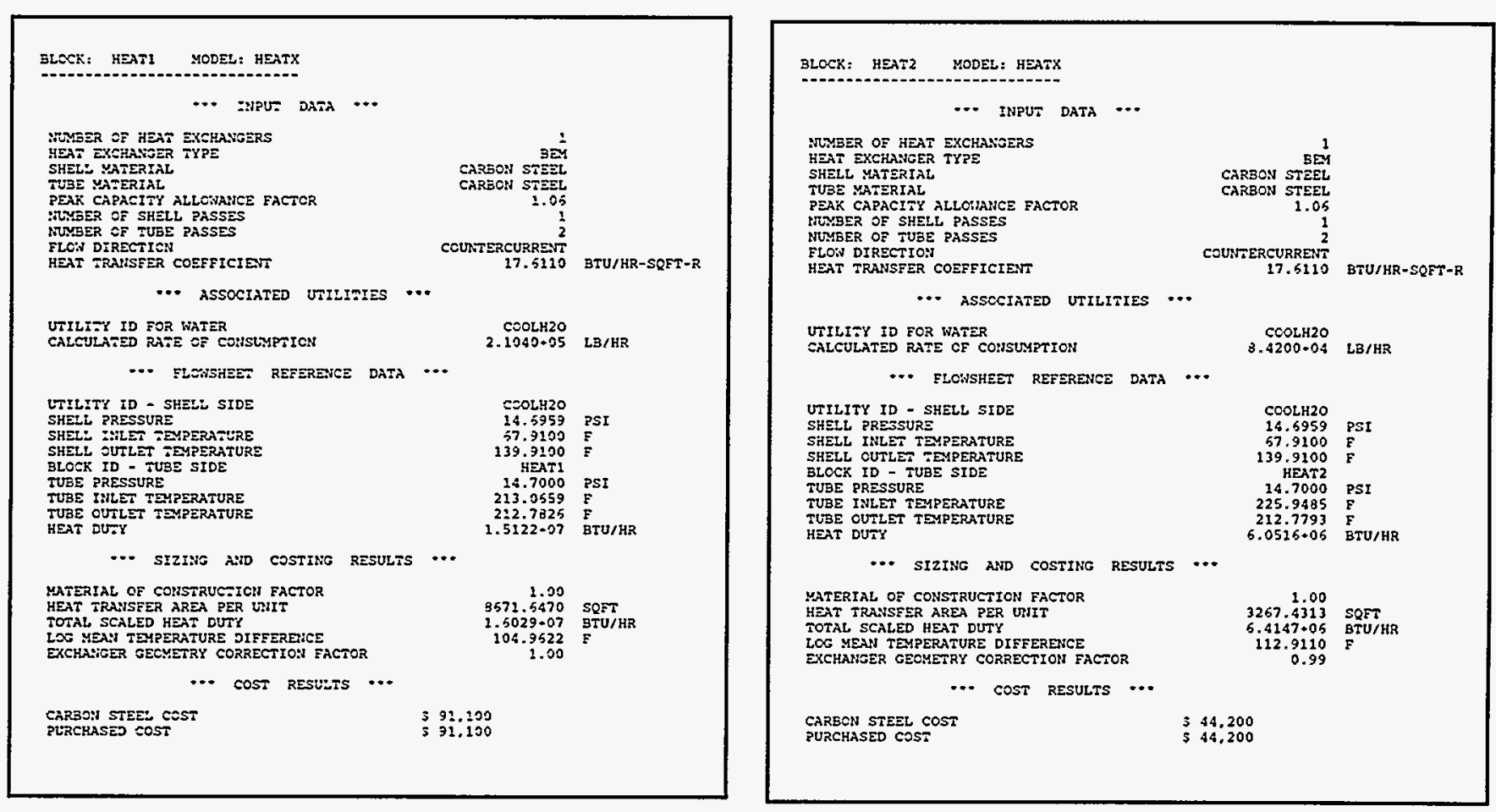

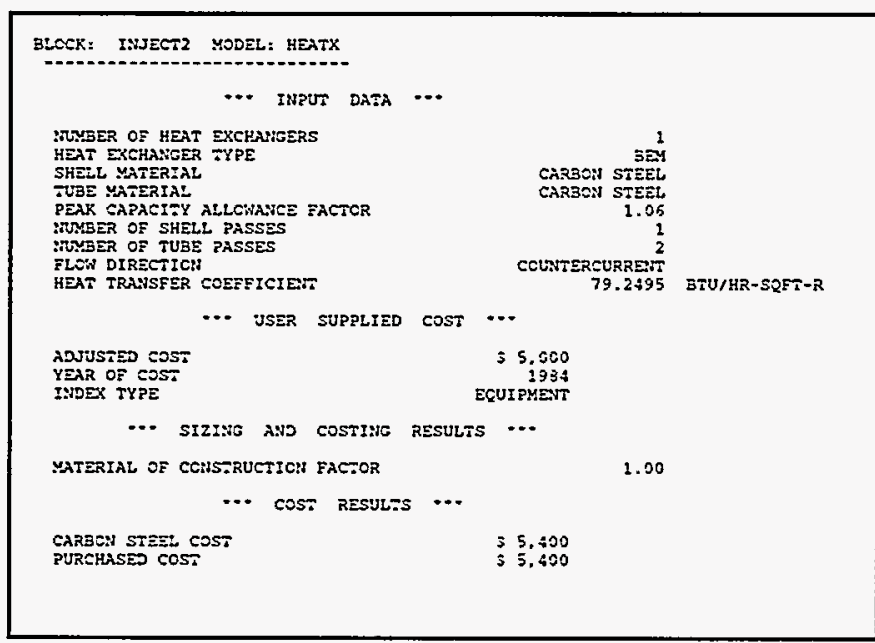

SLCCK: SCRUGEER MOJEL: USER

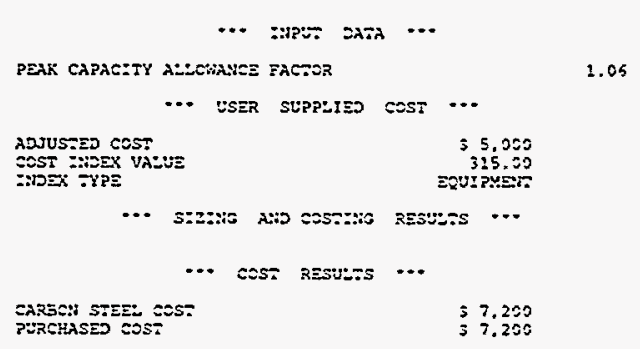

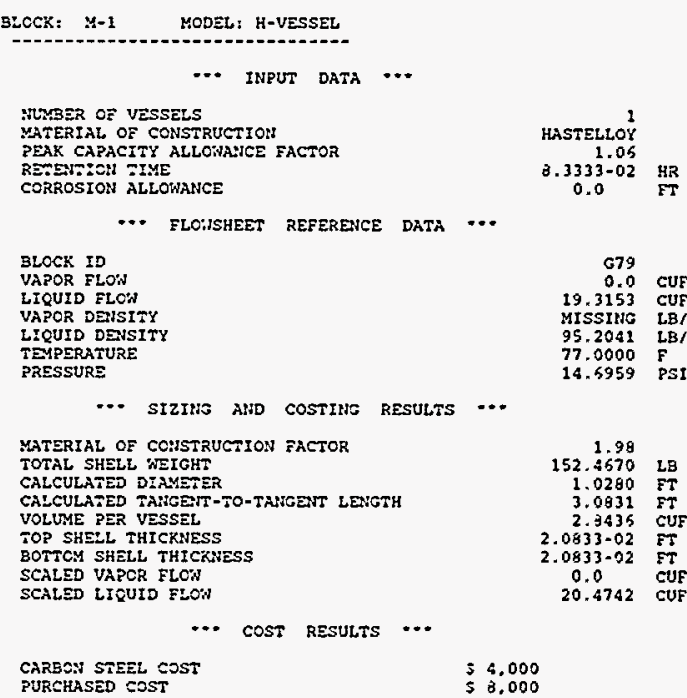




\section{BIOFILTER PROCESS PRODUCING GYPSUM - ECONOMIC EVALUATION}
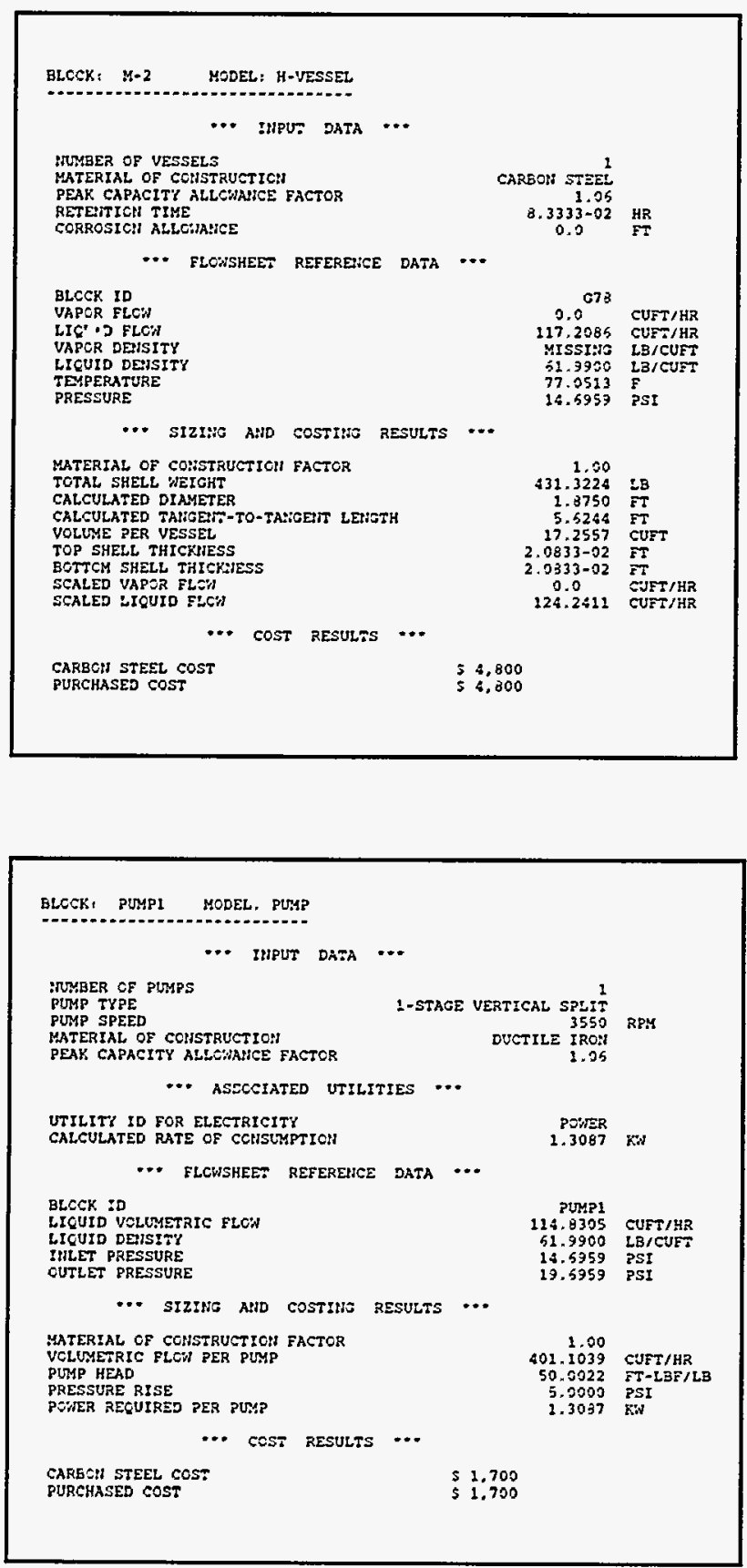

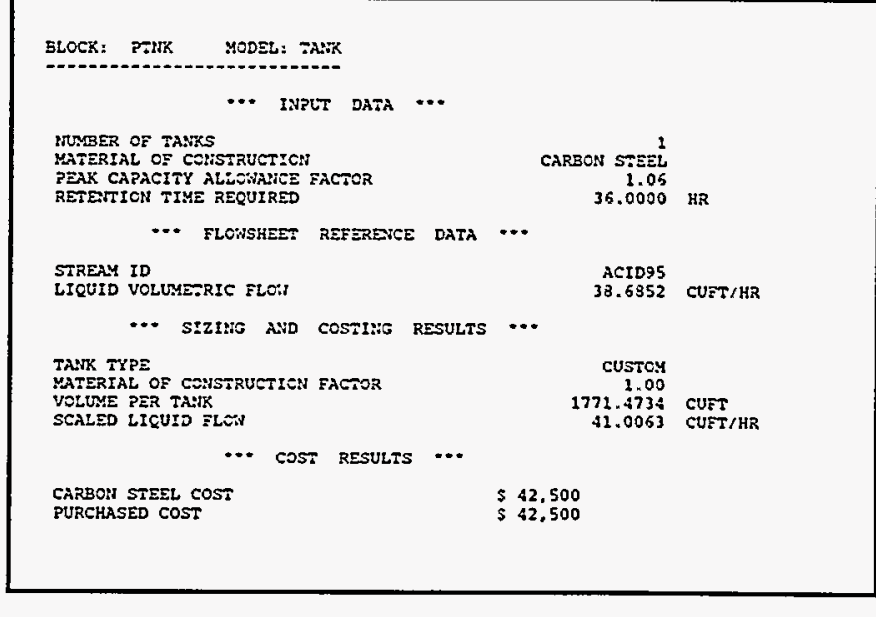

BLCCK: REACTOR MODEL: H-VESSEL

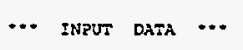

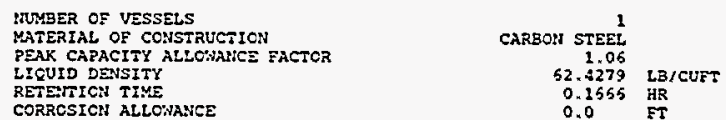

RETEMTICA TIME
CORRCSICM ALLONANCE

-.. FLONSHEET REFERENCE DATA ...

BLCSK ID
VAROR FLON
LICUID FLON
VAPOR DEISITY
TEYPERATURE

PRESSURE

.. siztio and costing RESULTS $\cdots$

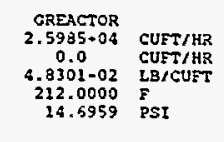

MATERIAL OE CONSTRUCTICN FACTOR

TTTAL SHELL NEICHT

CALCULATED DIAMETER

VOLUME PER VESSEL

TOP SHELL THICKNESS

SCALSD SHEL THICKS

SCALED VAPOR FLON

$$
\text { .. } \cos \text { Results } \cdots
$$

$\begin{array}{ll}\text { CARBOA STEEL COST } & \$ 5.000 \\ \text { PURCHASED COST } & \$ 5,000\end{array}$

\begin{tabular}{|c|c|c|c|}
\hline \multicolumn{4}{|l|}{ BLCCK: RPUMP MODEL: PUMP } \\
\hline$\cdots$ IIIPUT DATA & $\cdots$ & & \\
\hline $\begin{array}{l}\text { PUMP TYPE } \\
\text { PUMP SPEED } \\
\text { MATERIAL OF CONSTRUCTIOU FACTOR } \\
\text { PEAK CAPACITY ALLCAAICE FACTOR }\end{array}$ & 1-STAGE & $\begin{array}{r}\text { GE VERTICAL SPLIT } \\
3550 \\
3.70 \\
1.06\end{array}$ & RPM \\
\hline$\cdots$ ILCUSHEET REFEREICE & E DATA & $\cdots$ & \\
\hline $\begin{array}{l}\text { BLOCK ID } \\
\text { LIQUID VOLUYETRIC FLON } \\
\text { LICUID DESSITY } \\
\text { INLET PRESSURE } \\
\text { OUTLET PRESSURE }\end{array}$ & & $\begin{array}{r}\text { RPUNP } \\
1.2308=04 \\
62.4250 \\
16.7000 \\
19.7000\end{array}$ & $\begin{array}{l}\text { CUET/HR } \\
\text { LB/CUET } \\
\text { PSI } \\
\text { PSI }\end{array}$ \\
\hline$\cdots$ sIzImG גid costnic & RESULTS & $\cdots$ & \\
\hline $\begin{array}{l}\text { CALCULATED NUMBER OF PUMPS } \\
\text { FOTAE SCALED VOLUMETRIC FLCN } \\
\text { VOLWMETRIC FLCH PER PUMP } \\
\text { PLMP HEAD } \\
\text { PRESSURE RISE } \\
\text { POIIER REQUIRED PER PLYR }\end{array}$ & & $\begin{array}{r}2 \\
2.3045+04 \\
6522.9902 \\
50.0022 \\
5.0000 \\
17.0566\end{array}$ & $\begin{array}{l}\text { CUFT/HR } \\
\text { CUETLHR } \\
\text { ET-LBFILB } \\
\text { PSI } \\
\text { XW }\end{array}$ \\
\hline$\cdots \cos \pi$ RESULTS & s $\cdots$ & & \\
\hline $\begin{array}{lr} & \text { PER PIECE } \\
\text { CARBON STEEL COSI } & 35.200 \\
\text { PLREHASED COSI } & 519.200\end{array}$ & $\begin{array}{r}\text { TOTAL } \\
510.400 \\
538.300\end{array}$ & & \\
\hline
\end{tabular}

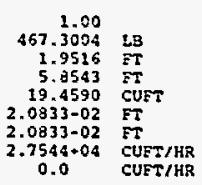


BIOFILTER PROCESS PRODUCING GYPSUM - ECONOMIC EVALUATION

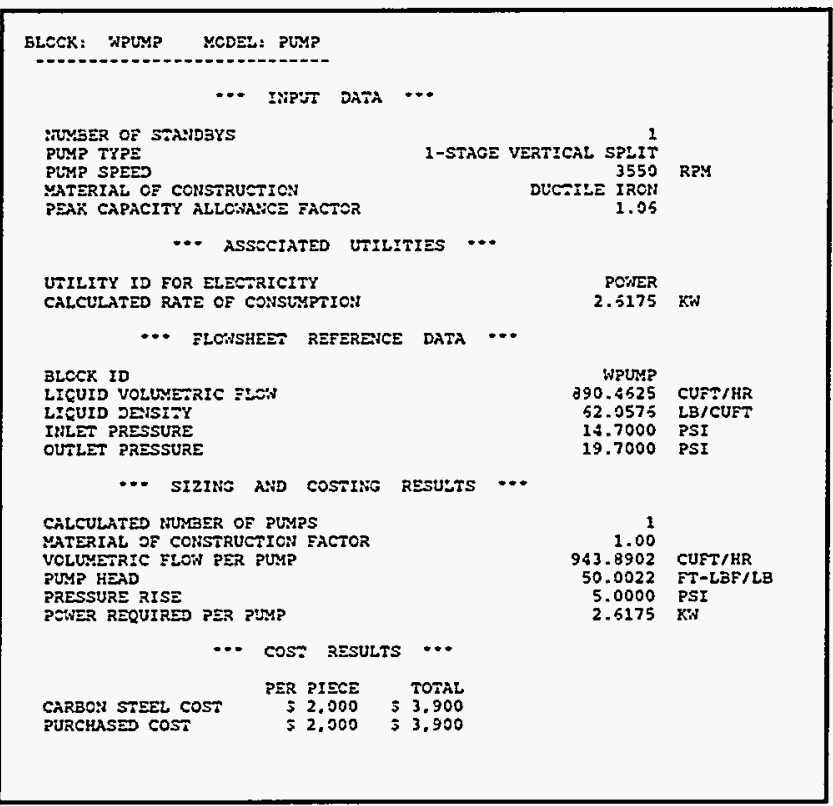

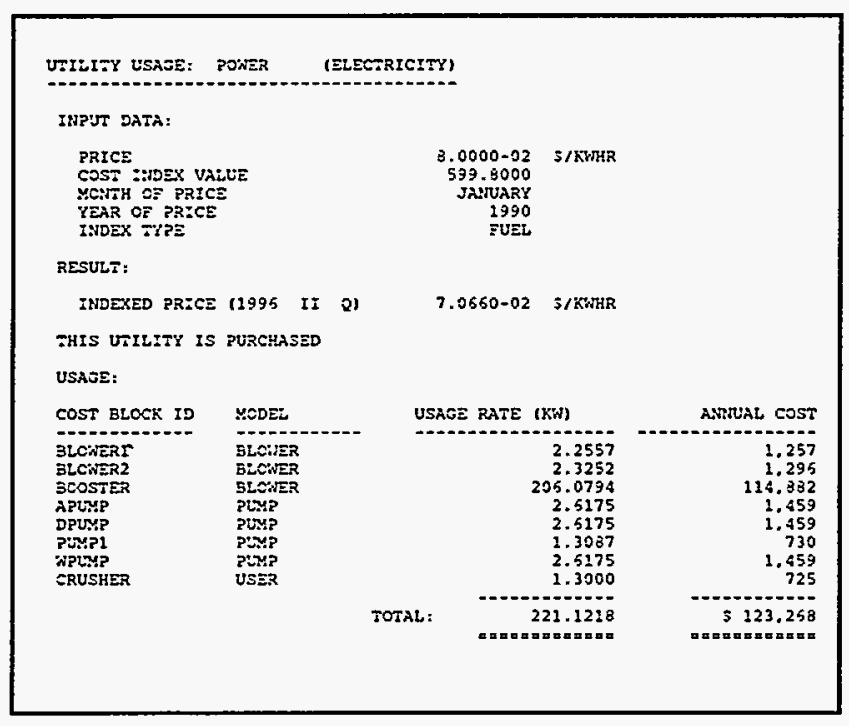

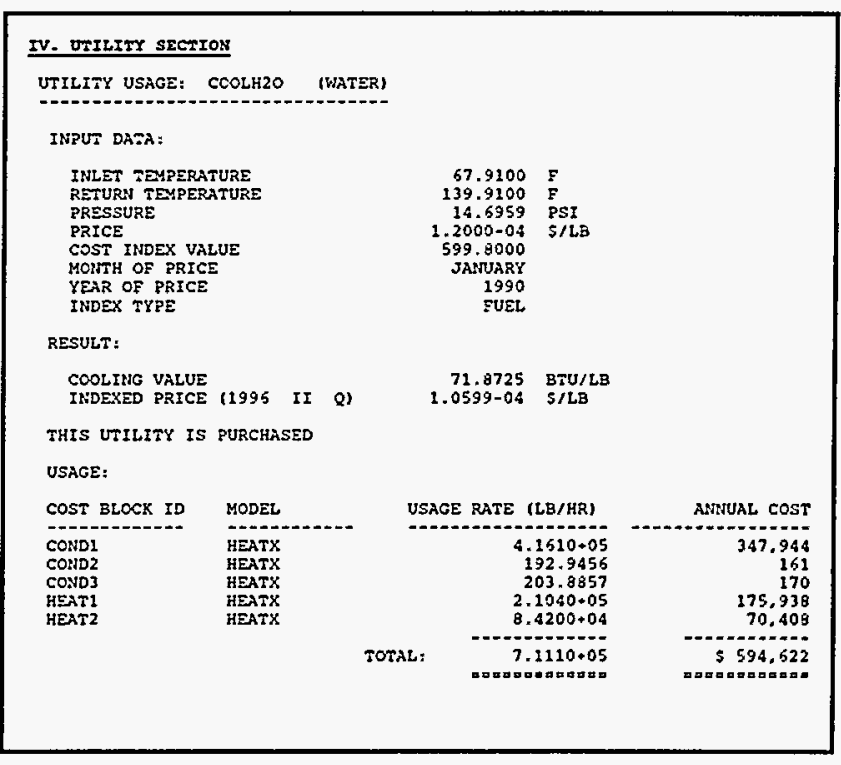

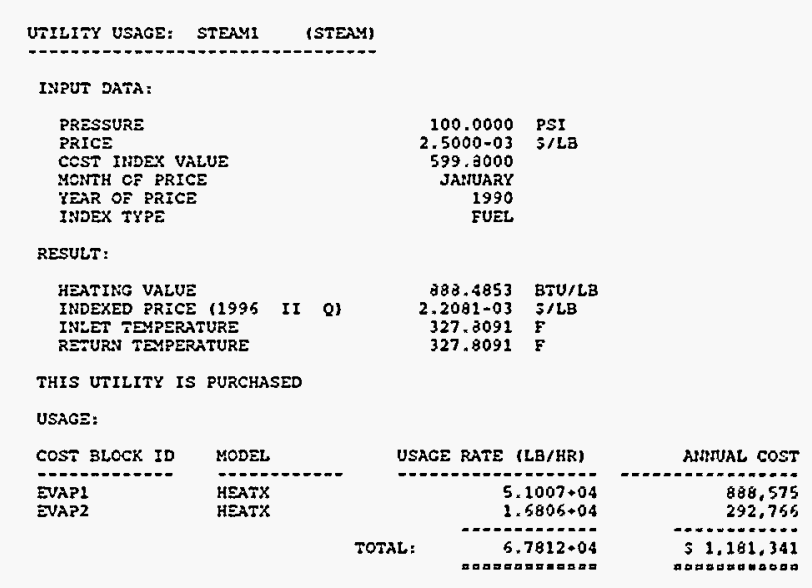




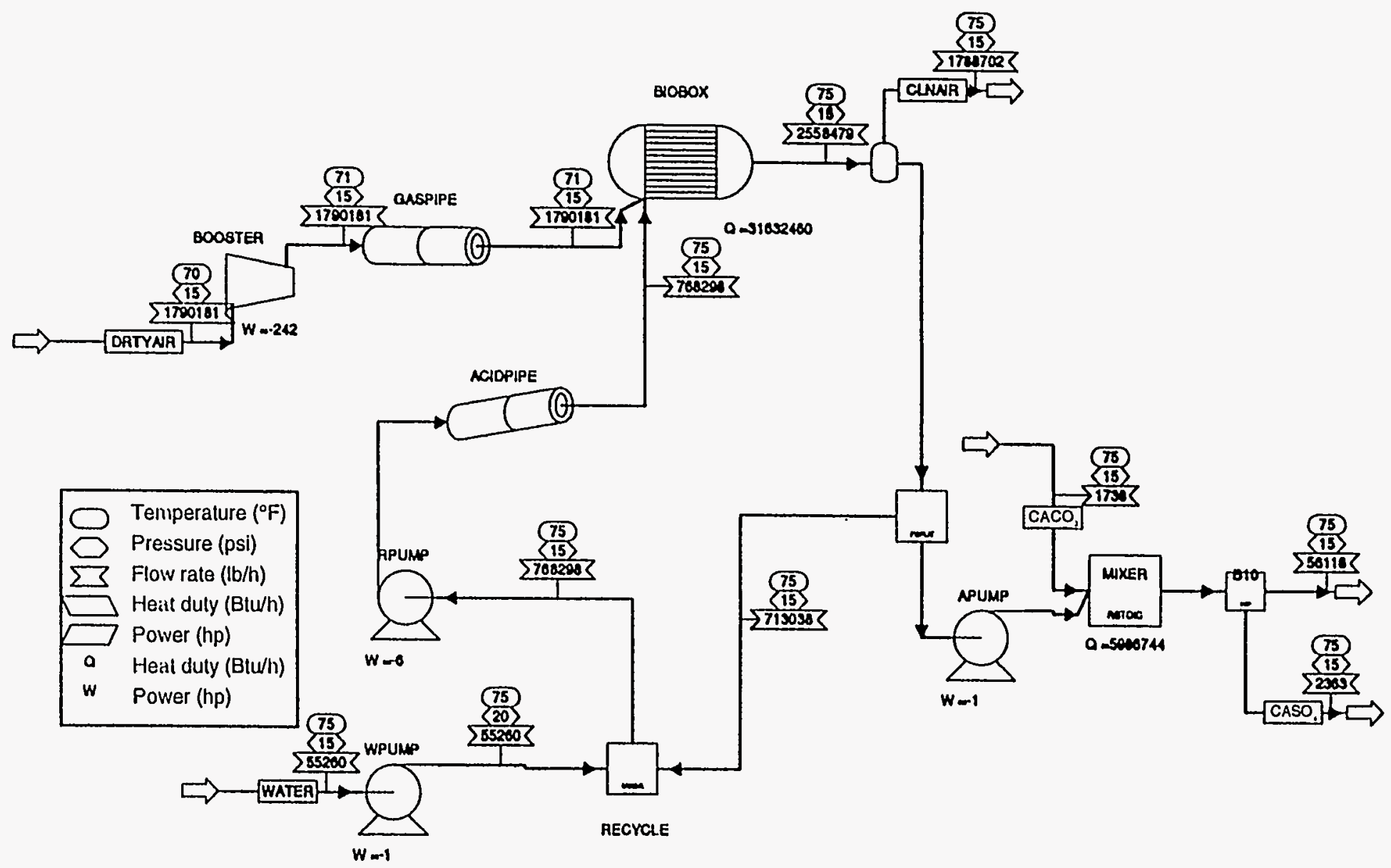

FIGURE A.6 Biofilter/Line Neutralizer PFD 


\section{BIOFILTER PROCESS WITH $3 \% \mathrm{H}_{2} \mathrm{SO}_{4}$ NEUTRALIZED - ECONOMIC EVALUATION}

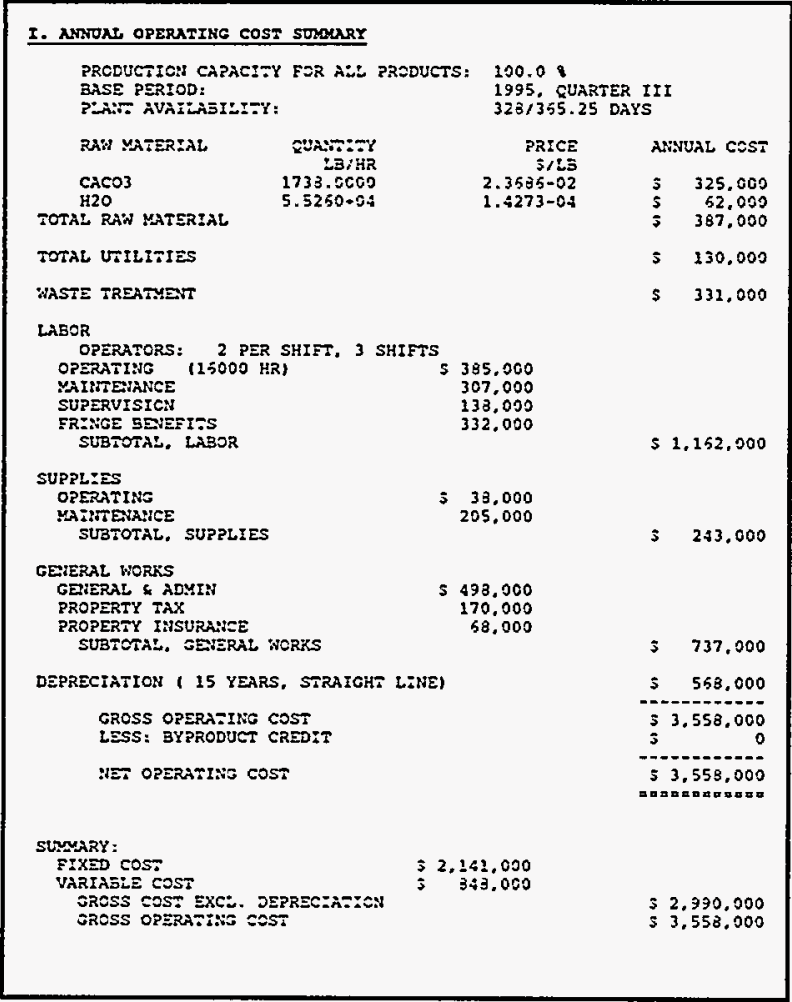

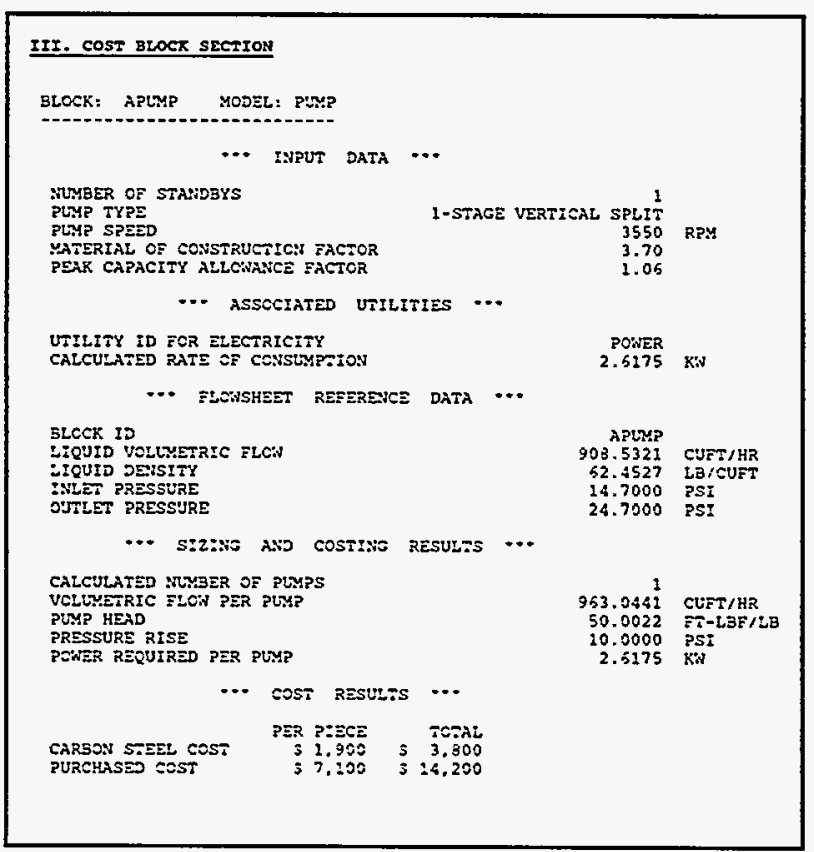

\section{PROCESS UNIT DTRECT COST SUMQARRY}

CCMPLETION: 1995, QUARTER III

$\operatorname{cosT} 310 \mathrm{cos}$ ID

guavTITY

QUANTITY
STANDBY

CARSON STEEL COS:
PURCHASED COST

COST BLOCK ID

QUANTITY

STANDSY

CARBON STEEL COS

PURCHASED COST

TOTAL EQUIPMENT COST

TOTAL INVESTMEMT

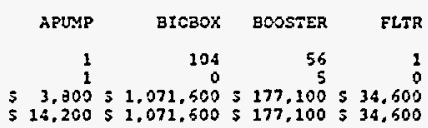

$$
\begin{array}{rrr}
\text { MIXER } & \text { RPUMP } & \text { UPUMP } \\
1 & 2 & 1 \\
5 & 1 & 1 \\
\$ 30.500 & \$ 15,300 & \$ 3,800 \\
\$ 105,500 & \$ 56,500 & \$ 3,800 \\
& \$ 1,464,400 & \\
& \$ 3,692,000 &
\end{array}
$$

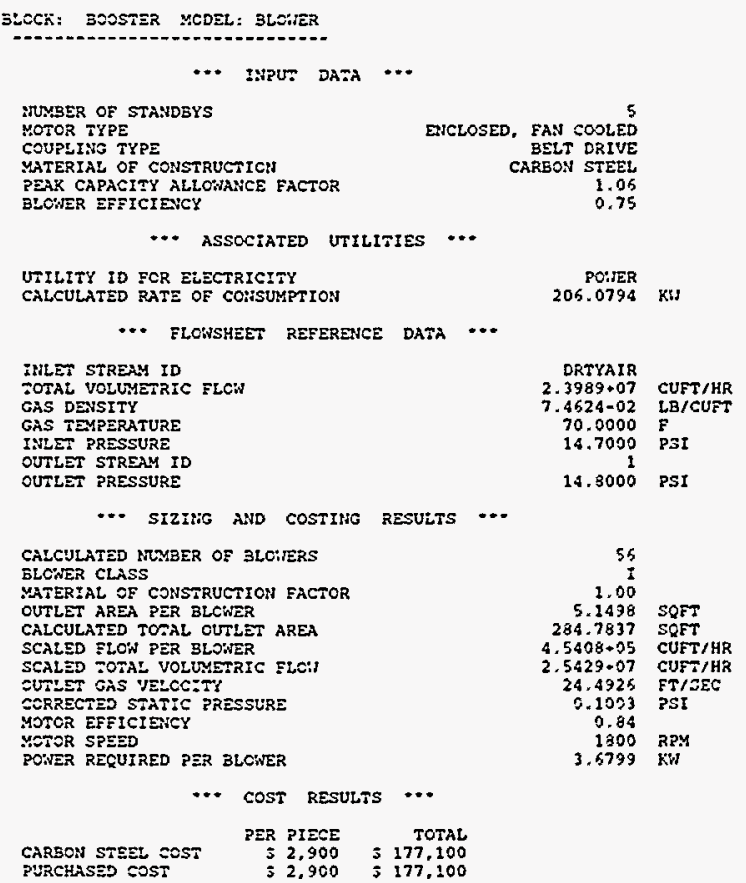


BIOFILTER PROCESS WITH $3 \% \mathrm{H}_{2} \mathrm{SO}_{4}$ NEUTRALIZED - ECONOMIC EVALUATION

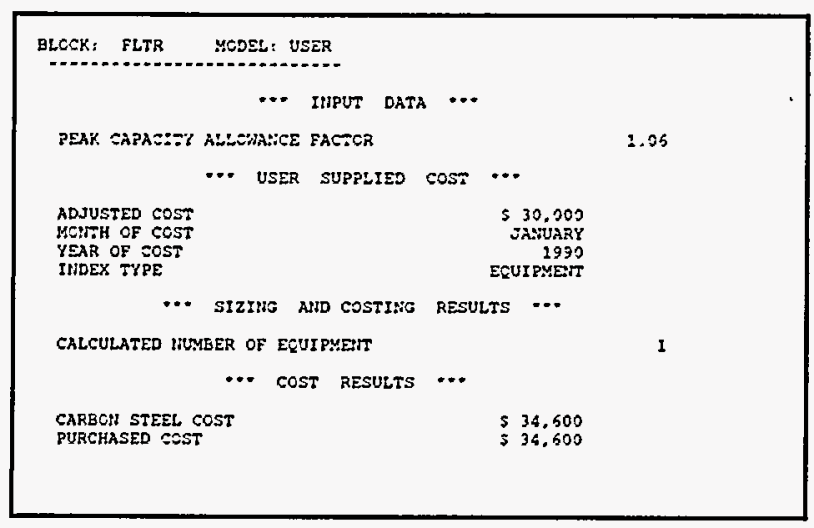

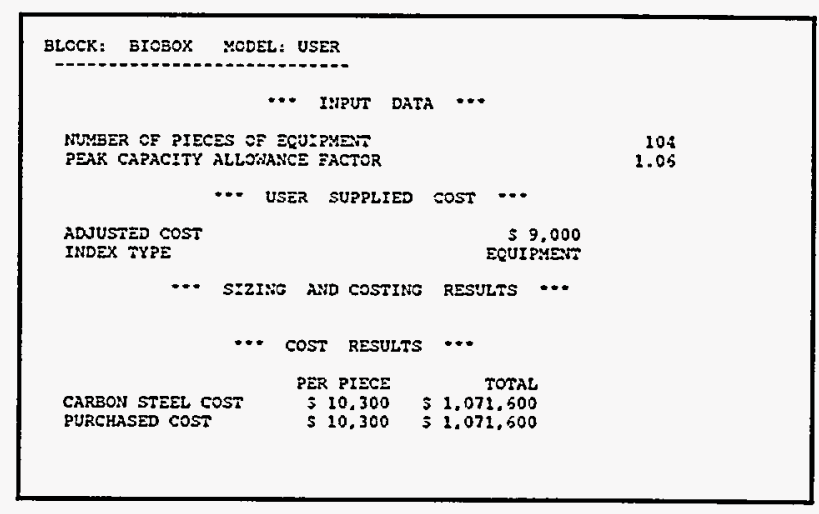

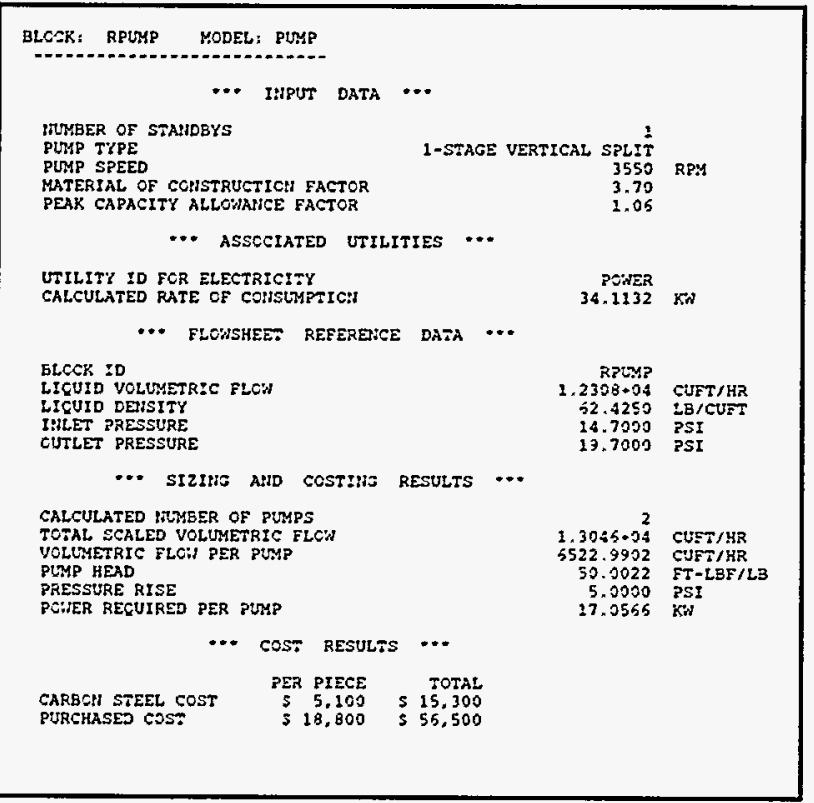
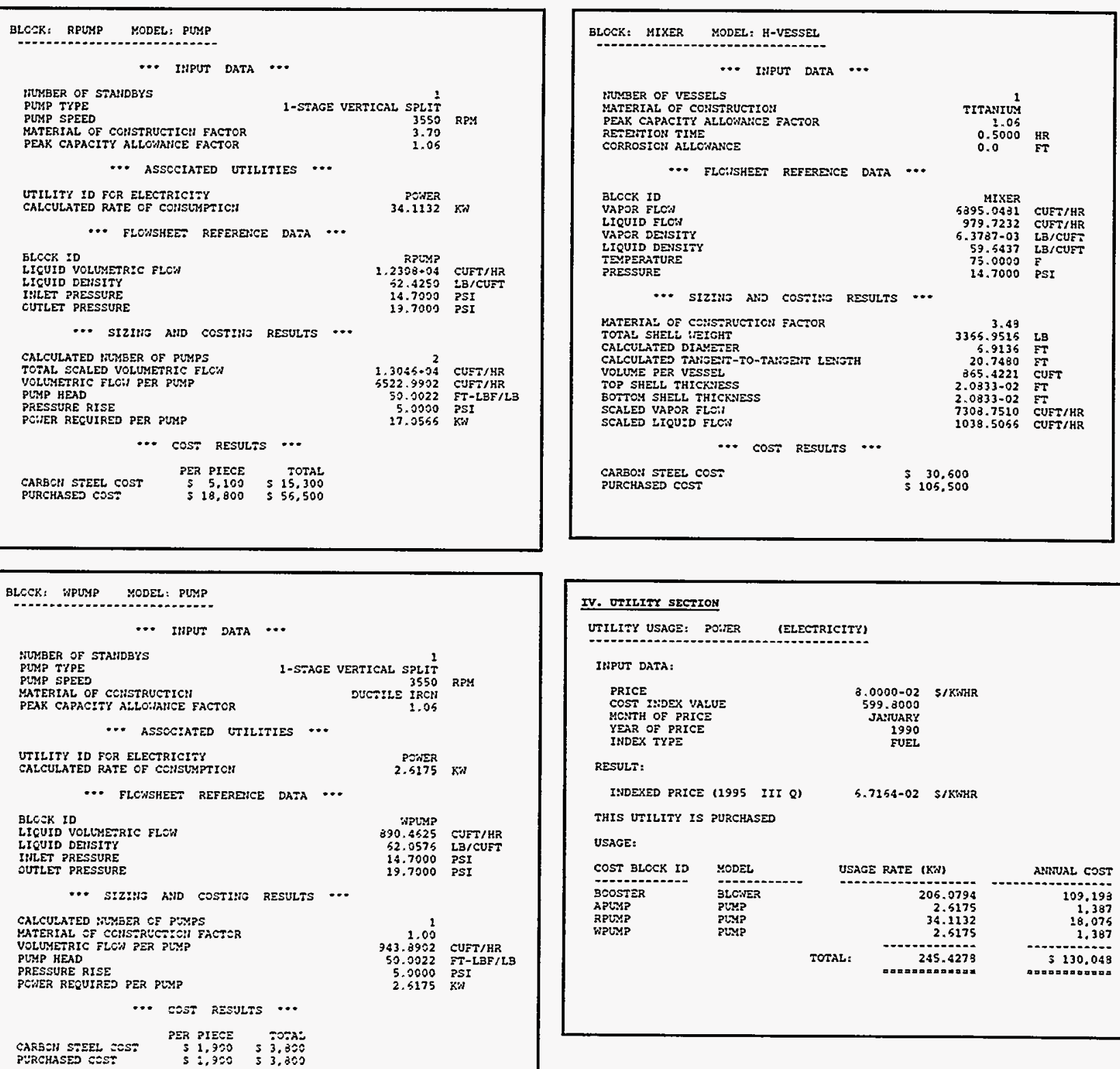

\section{OTILITY SECTION}

UTILITY USAGE: POARE (ELECTRICITY)

IMPUT DATA:

\begin{tabular}{|c|c|}
\hline 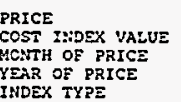 & $\begin{array}{r}3.0000-02 \\
599.8000 \\
\text { JA:UARY } \\
1990 \\
\text { EVEL }\end{array}$ \\
\hline
\end{tabular}

RESULT:

INDEXED PRICE (1995 III Q) $9.7254-02$ S/KKHR THIS UTILITY IS PURCHASED

USAGE:

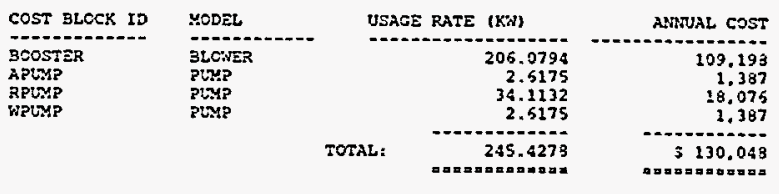




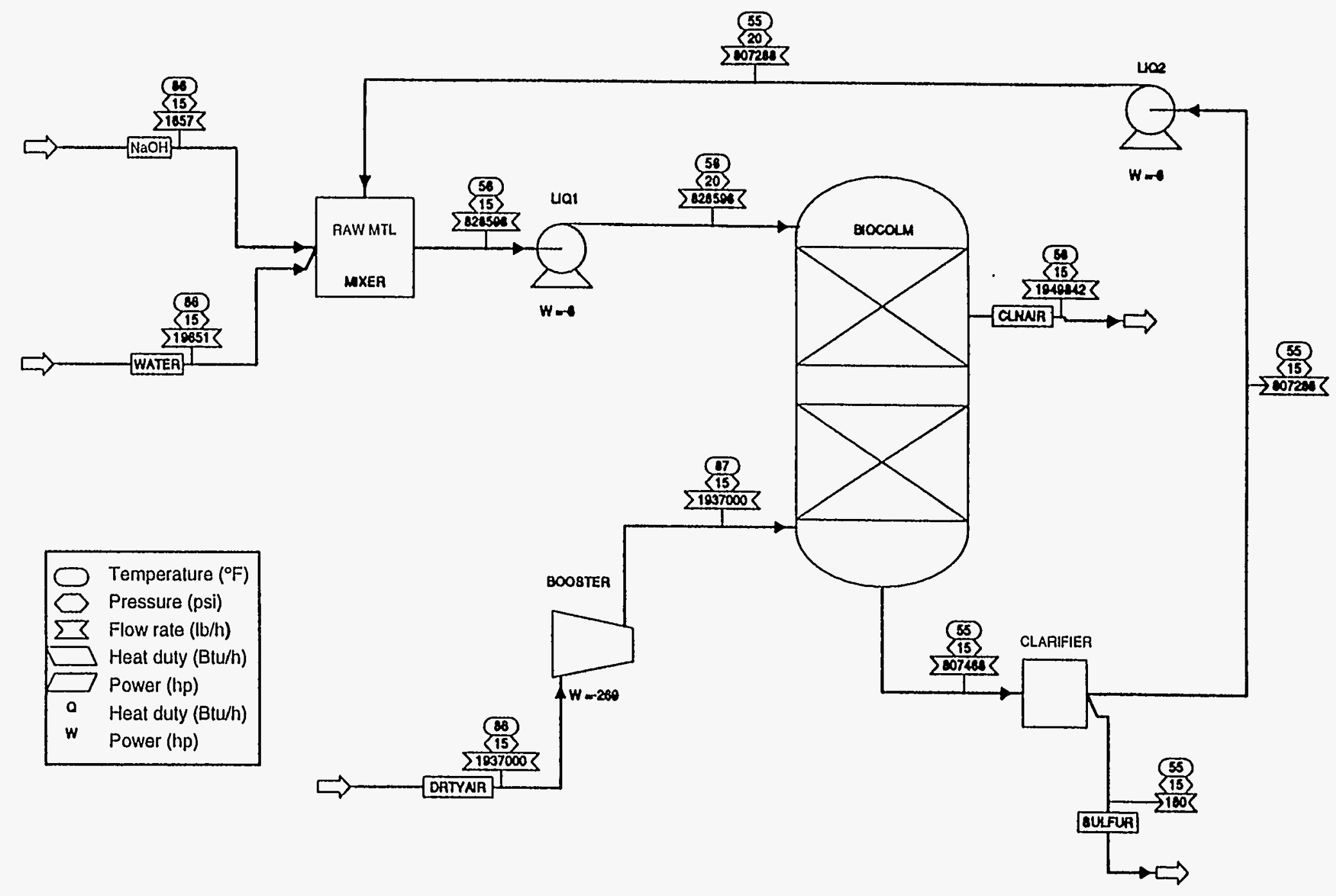

FIGURE A.7 Biocolumn PFD 
PACKED COLUMN FOR CS ${ }_{2}$ REMOVAL WITH SULFUR PRODUCTION - ECONOMIC EVALUATION

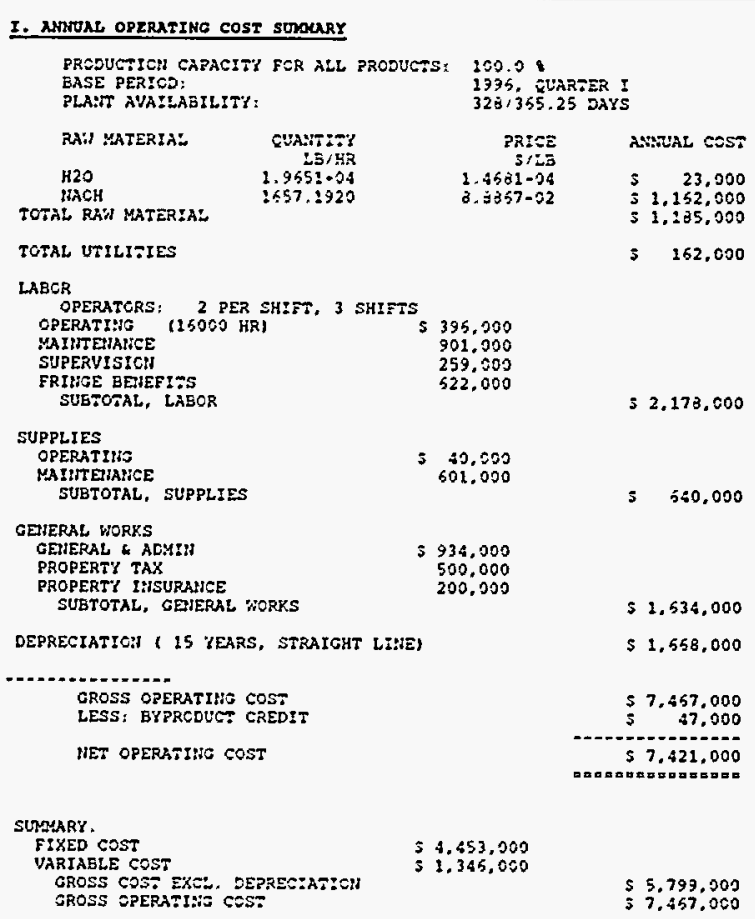

GROSS OPERATIME COST,
LESS: EYPRCDUE CREDT

MET OPERATISTC COST

SUMAARY.

$\begin{array}{ll}\text { FIXED COST } & \$ 4,453,000 \\ \text { VARIAELE COST } & \$ \$ 1,345,000\end{array}$

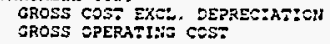

A:suas cos? $5 \quad 23.000$ $\$ 1.152 .000$ ; 162,000 $5,540.000$

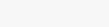

1. 534,000

$51,558,000$ $\$ 7.457 .0000$ $\$ 7.421 .000$

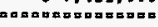

S 5.799 .209

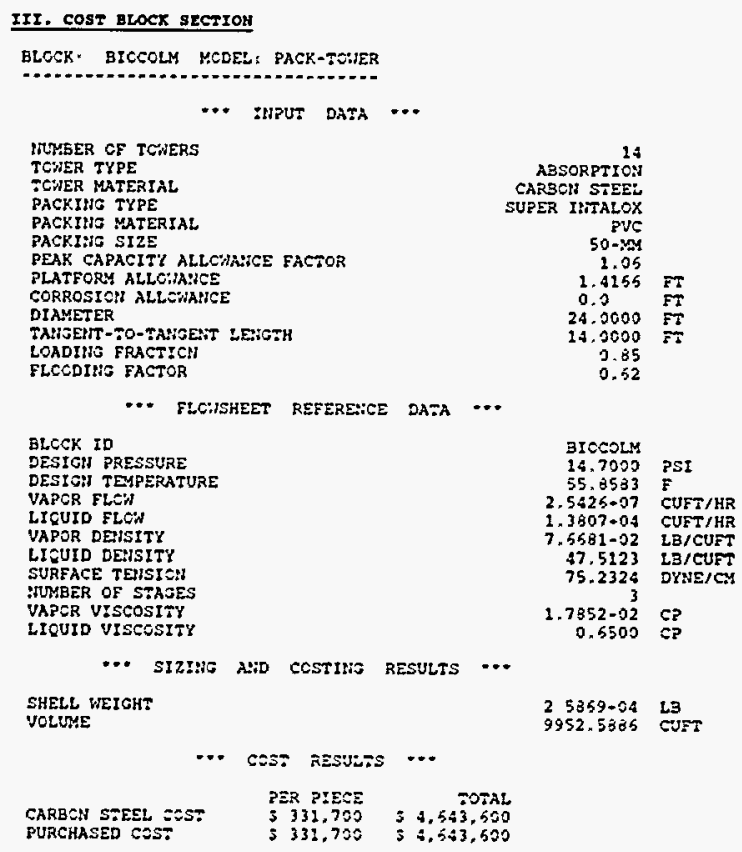

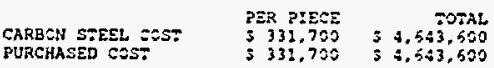

Brecos:

14.2005 PSI

$\begin{aligned} 55,3533 & \text { F } \\ 2,5425.07 & \text { CUFT/HR } \\ 1.36020 .04 & \text { CUFT/HR }\end{aligned}$

$3.5581-02$ LB/CUFT

$\begin{array}{lll}47.5123 & 23 / C U F T \\ 75.2324 & \text { DYNE } / \mathrm{CM}\end{array}$

$1.7552-02 \mathrm{CP}$
0.5500 $\begin{array}{ll}25359-04 & 23 \\ 9952.5505 & \text { CUIT }\end{array}$

II. EQOTPMENT DIRECT COST SUNPQRRY

CEMPLETIS:: 1995, GUARTER I

$\cos 3$ BLCCK 19

QUANTITY

STARBEYI STEEL COST

BICCOLM BOOSTER CLAR:F: LIQ1

COST BLCCK ID

QUANTITY

STANDBY

CARBON STEEL COST

TOTAL EQUIPUETT COS:

TOTAL INVESTMEN:

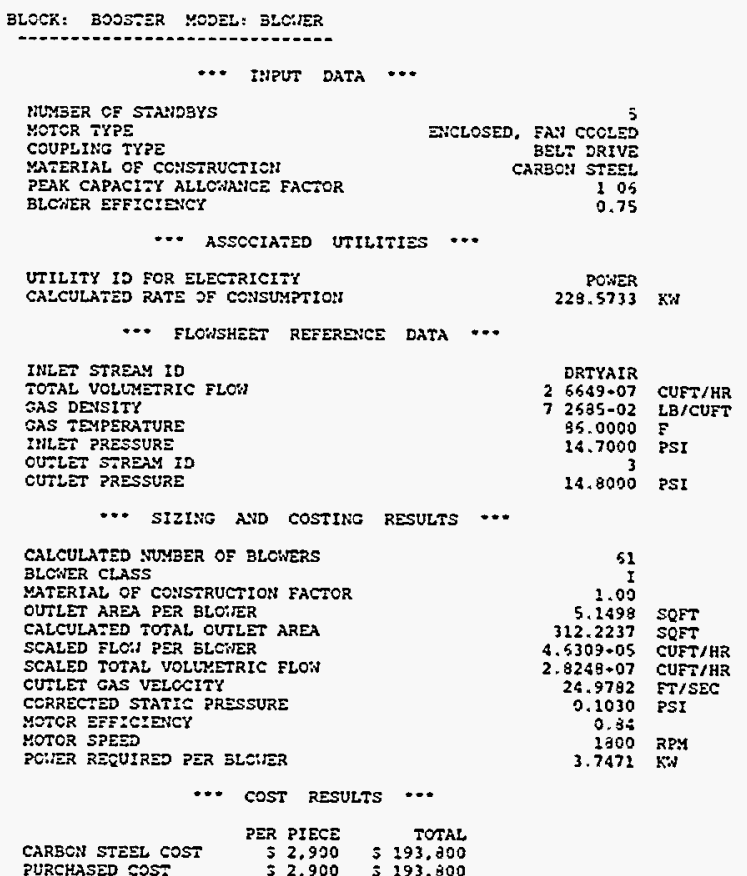




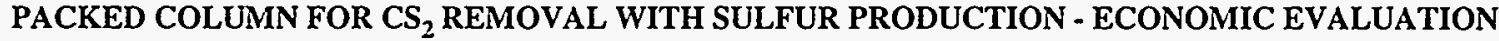

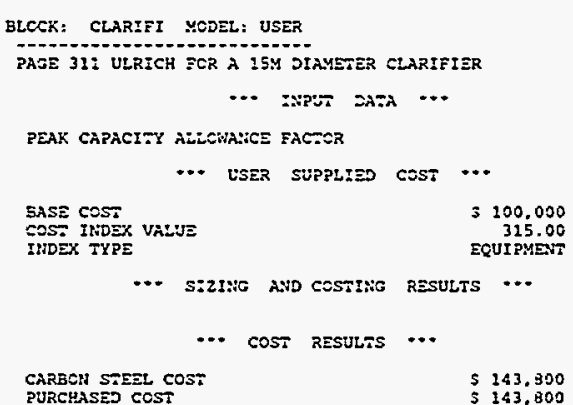

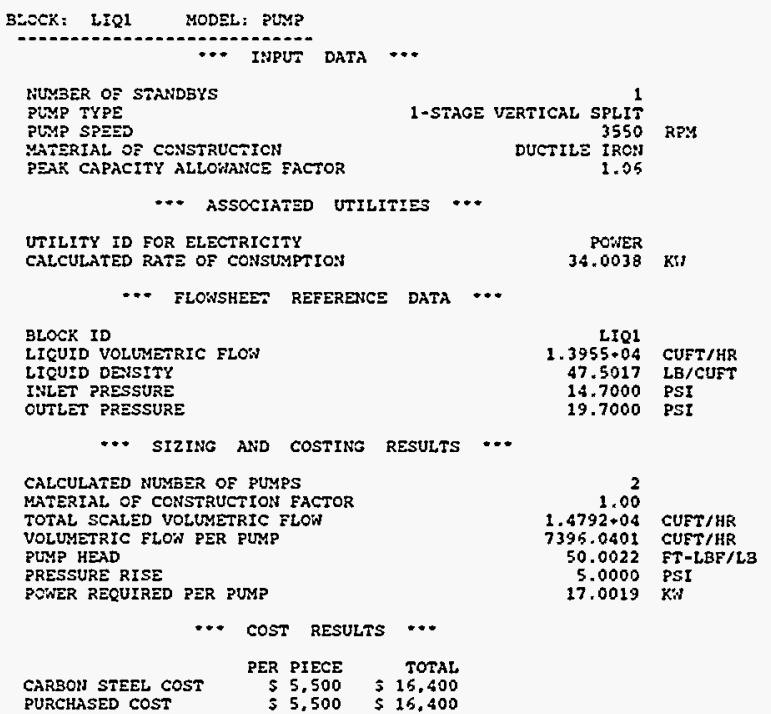


APPENDIX B:

CALCULATION OF DISPOSAL COSTS 


\section{APPENDIX B:}

\section{CALCULATION OF DISPOSAL COSTS}

Calculations for the possible amounts of sulfuric acid, sulfur, and gypsum that may be produced by sulfide recovery from Teepak air are based on averaged flow from two different airborne sulfide-contaminant sources at Teepak:

Teepak Source Number 1

Air flow

Contaminants

$$
\mathrm{CS}_{2}
$$

$\mathrm{H}_{2} \mathrm{~S}$

Teepak Source Number 2
Air flow
$354,000.00 \mathrm{~m}^{3} / \mathrm{h}$
Contaminants
$\mathrm{CS}_{2}$
$\mathrm{H}_{2} \mathrm{~S}$

\section{B.1 SOURCE 1 PRODUCTION RATES}

The $\mathrm{CS}_{2}$ emission from the first source is

$$
\begin{aligned}
& =\left(293.00 \mathrm{mg} \mathrm{CS}{ }_{2} / \mathrm{m}^{3}\right)\left(2.90 \times 10^{5} \mathrm{~m}^{3} / \mathrm{h}\right) \\
& =8.50 \times 10^{7} \mathrm{mg} \mathrm{CS}_{2} / \mathrm{h} .
\end{aligned}
$$

The amount of sulfur that may be produced from the $\mathrm{CS}_{2}$ emission is calculated by multiplying the total $\mathrm{CS}_{2}$ emission by the ratio of the atomic weight of sulfur to the molecular weight of $\mathrm{CS}_{2}$ :

$$
\begin{aligned}
& =\left[8.50 \times 10^{7} \mathrm{mg} \mathrm{CS} 2 / \mathrm{h}\right]\left[2.00(32.06) \mathrm{mg} \mathrm{S} / 76.13 \mathrm{mg} \mathrm{CS}_{2}\right] \\
& =7.16 \times 10^{7} \mathrm{mg} \mathrm{S} / \mathrm{h} .
\end{aligned}
$$

Similarly, the amount of sulfuric acid that may be produced from the sulfur is

$$
\begin{aligned}
& =\left[8.50 \times 10^{7} \mathrm{mg} \mathrm{CS}_{2} / \mathrm{h}\right]\left[2.00(98.07) \mathrm{mg} \mathrm{H}_{2} \mathrm{SO}_{4} / 76.13 \mathrm{mg} \mathrm{CS}_{2}\right] \\
& =2.19 \times 10^{8} \mathrm{mg} \mathrm{H}_{2} \mathrm{SO}_{4} / \mathrm{h} .
\end{aligned}
$$


Likewise, the amount of gypsum that may be produced is

$$
\begin{aligned}
& =\left[8.50 \times 10^{7} \mathrm{mg} \mathrm{CS}_{2} / \mathrm{h}\right]\left[2.00(172.18) \mathrm{mg} \mathrm{CaSO}_{4} * 2 \mathrm{H}_{2} \mathrm{O} / 76.13 \mathrm{mg} \mathrm{CS}_{2}\right] \\
& =3.84 \times 10^{8} \mathrm{mg} \mathrm{CaSO}_{4} * 2 \mathrm{H}_{2} \mathrm{O} / \mathrm{h} .
\end{aligned}
$$

The $\mathrm{H}_{2} \mathrm{~S}$ emission from Source 1 is calculated as follows:

$$
\left(324.00 \mathrm{mg} \mathrm{H}_{2} \mathrm{~S} / \mathrm{m}^{3}\right)\left(2.90 \times 10^{5} \mathrm{~m}^{3} / \mathrm{h}\right)=9.40 \times 10^{7} \mathrm{mg} \mathrm{H}_{2} \mathrm{~S} / \mathrm{h} .
$$

The amount of sulfur from $\mathrm{H}_{2} \mathrm{~S}$ is

$$
\begin{aligned}
& =\left(9.40 \times 10^{7} \mathrm{mg} \mathrm{H}_{2} \mathrm{~S} / \mathrm{h}\right)\left(32.06 \mathrm{mg} \mathrm{S} / 34.08 \mathrm{mg} \mathrm{H}_{2} \mathrm{~S}\right) \\
& =8.84 \times 10^{7} \mathrm{mg} \mathrm{S} / \mathrm{h} .
\end{aligned}
$$

The amount of sulfuric acid from $\mathrm{H}_{2} \mathrm{~S}$ is

$$
\begin{aligned}
& =\left(9.40 \times 10^{7} \mathrm{mg} \mathrm{H}_{2} \mathrm{~S} / \mathrm{h}\right)\left(98.07 \mathrm{mg} \mathrm{H}_{2} \mathrm{SO}_{4} / 34.08 \mathrm{mg} \mathrm{H}_{2} \mathrm{~S}\right) \\
& =2.70 \times 10^{8} \mathrm{mg} \mathrm{H}_{2} \mathrm{SO}_{4} / \mathrm{h} .
\end{aligned}
$$

The amount of gypsum from $\mathrm{H}_{2} \mathrm{~S}$ is

$$
\begin{aligned}
& =\left(9.40 \times 10^{7} \mathrm{mg} \mathrm{H}_{2} \mathrm{~S} / \mathrm{h}\right)\left(172.18 \mathrm{mg} \mathrm{CaSO}_{4} * 2 \mathrm{H}_{2} \mathrm{O} / 34.08 \mathrm{mg} \mathrm{H}_{2} \mathrm{~S}\right) \\
& =4.75 \times 10^{8} \mathrm{mg} \mathrm{CaSO}_{4} * 2 \mathrm{H}_{2} \mathrm{O} / \mathrm{h} .
\end{aligned}
$$

The total production of sulfur, sulfuric acid, and gypsum produced from Source 1 is calculated by adding the respective contributions from the $\mathrm{H}_{2} \mathrm{~S}$ and $\mathrm{CS}_{2}$ in the airstream. The total potential production rates from Source 1 are

$$
\begin{aligned}
& \text { Sulfur total }=7.16 \times 10^{7}+8.84 \times 10^{7} \\
& =1.60 \times 10^{8} \mathrm{mg} \mathrm{S} / \mathrm{h} \text {; } \\
& \text { Sulfuric acid total }=2.19 \times 10^{8}+2.70 \times 10^{8} \\
& =4.89 \times 10^{8} \mathrm{mg} \mathrm{H}_{2} \mathrm{SO}_{4} / \mathrm{h} \text {; and } \\
& \text { Gypsum total }=3.84 \times 10^{8}+4.75 \times 10^{8} \\
& =8.59 \times 10^{8} \mathrm{mg} \mathrm{CaSO}_{4} * 2 \mathrm{H}_{2} \mathrm{O} / \mathrm{h} \text {. }
\end{aligned}
$$




\section{B.2 SOURCE 2 PRODUCTION RATES}

The $\mathrm{CS}_{2}$ emission from Source 2 is

$=\left(293.00 \mathrm{mg} \mathrm{CS} 2 / \mathrm{m}^{3}\right)\left(3.54 \times 10^{5} \mathrm{~m}^{3} / \mathrm{h}\right)$

$=1.04 \times 10^{8} \mathrm{mg} \mathrm{CS} / \mathrm{h}$.

The amount of sulfur that may be produced from $\mathrm{CS}_{2}$ is

$=\left[1.04 \times 10^{8} \mathrm{mg} \mathrm{CS}_{2} / \mathrm{h}\right]\left[2.00(32.06) \mathrm{mg} \mathrm{S} / 76.13 \mathrm{mg} \mathrm{CS}_{2}\right]$

$=8.76 \times 10^{7} \mathrm{mg} \mathrm{S} / \mathrm{h}$.

Similarly, the amount of pure sulfuric acid is

$$
\begin{aligned}
& =\left[1.04 \times 10^{8} \mathrm{mg} \mathrm{CS}_{2} / \mathrm{h}\right]\left[2.00(98.07) \mathrm{mg} \mathrm{H}_{2} \mathrm{SO}_{4} / 76.13 \mathrm{mg} \mathrm{CS}_{2}\right] \\
& =2.68 \times 10^{8} \mathrm{mg} \mathrm{H}_{2} \mathrm{SO}_{4} / \mathrm{h} .
\end{aligned}
$$

Likewise, the amount of gypsum is:

$$
\begin{aligned}
& =\left[1.04 \times 10^{8} \mathrm{mg} \mathrm{CS}_{2} / \mathrm{h}\right]\left[2.00(172.18) \mathrm{mg} \mathrm{CaSO}_{4} * 2 \mathrm{H}_{2} \mathrm{O} / 76.13 \mathrm{mg} \mathrm{CS}_{2}\right] \\
& =4.70 \times 10^{8} \mathrm{mg} \mathrm{CaSO}_{4} * 2 \mathrm{H}_{2} / \mathrm{h} .
\end{aligned}
$$

Since the amount of $\mathrm{H}_{2} \mathrm{~S}$ from Source 2 is only $0.40 \mathrm{mg} / \mathrm{m}^{3}$, it is assumed that this very small amount of hydrogen sulfide makes no contribution to the amount of sulfur, sulfuric acid, or gypsum that may be produced.

\section{B.3 TOTAL PRODUCTION RATES FROM SOURCES 1 AND 2}

The total sulfur, sulfuric acid, and gypsum collection possibilities are calculated by adding the contributions from each source (a $96 \%$ yield is assumed):

Total sulfur production rate $=(7.16+8.84+8.76)(0.96) \times 10^{7}$

$$
=2.38 \times 10^{8} \mathrm{mg} \mathrm{S} / \mathrm{h}
$$

Total sulfuric acid production $=(2.19+2.70+2.68)(0.96) \times 10^{8}$

$$
=7.27 \times 10^{8} \mathrm{mg} \mathrm{H}_{2} \mathrm{SO}_{4} / \mathrm{h}
$$

Total gypsum production rate $=(3.84+4.75+4.70)(0.96) \times 10^{8}$

$$
=1.28 \times 10^{9} \mathrm{mg} \mathrm{CaSO}_{4} * 2 \mathrm{H}_{2} \mathrm{O} / \mathrm{h} \text {. }
$$


The yearly production rates are as follows:

$\begin{aligned} \text { Sulfur } & =\left(2.38 \times 10^{8} \mathrm{mg} \mathrm{S} / \mathrm{h}\right)\left(1.10 \times 10^{-9} \mathrm{ton} / 1.00 \mathrm{mg}\right)\left(1.00 \mathrm{~h} / 1.14 \times 10^{-4} \mathrm{yr}\right) \\ & =2,296.49 \text { tons/yr; }\end{aligned}$

Sulfuric acid $=\left(7.27 \times 10^{8} \mathrm{mg} \mathrm{H}_{2} \mathrm{SO}_{4} / \mathrm{h}\right)\left(1.10 \times 10^{-9} \mathrm{ton} / 1.00 \mathrm{mg}\right)\left(1.00 \mathrm{~h} / 1.14 \times 10^{-4} \mathrm{yr}\right)$ $=7,014.91$ tons $/ y r$;

Gypsum $=\left(1.28 \times 10^{9} \mathrm{mg} \mathrm{CaSO}_{4} * 2 \mathrm{H}_{2} \mathrm{O} / \mathrm{h}\right)\left(1.10 \times 10^{-9} \mathrm{ton} / 1.00 \mathrm{mg}\right)\left(1.00 \mathrm{~h} / 1.14 \times 10^{-4} \mathrm{yr}\right)$ $=12,350.88$ tons $/ \mathrm{yr}$.

\section{B.4 3\% SULFURIC ACID SOLUTION}

\section{B.4.1 Amount Produced}

The amount of $3 \%$ sulfuric acid that is produced from the biofilter is

$=(7,014.91$ tons $/ y r)[1+(97 / 3)]$

$=233,830.33$ tons $/ y r$.

\section{B.4.2 Volume}

In order to calculate the disposal cost for Teepak's 233,830.33-tons/yr 3\% sulfuric acid stream, the volume of the stream must be calculated. The density of a $3 \%$ sulfuric acid solution is about $63.96 \mathrm{lb} / \mathrm{ft}^{3}$ or $0.86 \mathrm{ton} / \mathrm{yd}^{3}$.

$$
\begin{aligned}
\text { Volume } & =(233,830.33 \mathrm{tons} / \mathrm{yr}) /\left(0.86 \mathrm{ton} / \mathrm{yd}^{3}\right) \\
& =271,895.73 \mathrm{yd}^{3} / \mathrm{yr}, \text { or } \\
& =54,922,937.46 \mathrm{gal} / \mathrm{yr} .
\end{aligned}
$$

\section{B.4.3 Disposal Cost}

The cost for the disposal of a $3 \%$ sulfuric acid solution is $\$ 0.60$ to $\$ 0.90$ per gallon; therefore, a cost range was calculated:

$$
\begin{aligned}
\text { Minimum cost } & =(54,922,937.46 \mathrm{gal} / \mathrm{yr})(\$ 0.60 / \mathrm{gal}) \\
& =\$ 32,953,762.48 / \mathrm{yr}, \text { and } \\
\text { Maximum cost } & =(54,922,937.46 \mathrm{gal} / \mathrm{yr})(\$ 0.90 / \mathrm{gal}) \\
& =\$ 49,430,643.71 / \mathrm{yr} .
\end{aligned}
$$




\section{B.4.4 Taxes}

For acid disposal, there is usually a city tax of about $\$ 0.025 / \mathrm{gal}$ and a hazardous waste tax of about $\$ 0.030 /$ gal. The total tax is about $\$ 0.055 /$ gal. The total tax is

$$
(\$ 0.055 / \mathrm{gal})(54,922,937.46 \mathrm{gal} / \mathrm{yr})=\$ 3,020,761.56 / \mathrm{yr}
$$

The disposal cost range, including taxes, is

$\$ 35,974,524.04 / \mathrm{yr}$ to $\$ 52,451,405.27 / \mathrm{yr}$.

\section{B.4.5 Transportation Cost}

If the distance over which the acid is transported is less than $500 \mathrm{mi}$, the cost is $\$ 914.00$ per load (one load $=4,500 \mathrm{gal}$ ). The total volume (in gallons) divided by 4,500 gives the total number of loads:

$(54,915,875.75 \mathrm{gal} / \mathrm{yr}) /(4,500.00 \mathrm{gal} / \mathrm{load})=12,203.53 \mathrm{loads} / \mathrm{yr}$.

The transportation cost for 12,204 loads is

$(\$ 914.00 /$ load $)(12,204$ loads $)=\$ 11,154,456.00 / \mathrm{yr}$

\section{B.4.6 Total Disposal Cost}

The total annual disposal cost for $3 \%$ sulfuric acid, including taxes and transportation costs, is

$\$ 47,128,980.04$ to $\$ 63,605,861.27$. 


\section{B.5 PURE SULFURIC ACID}

\section{B.5.1 Volume}

The density of pure sulfuric acid is about $114.44 \mathrm{lb} / \mathrm{ft}^{3}$ or $1.54 \mathrm{tons} / \mathrm{yd}^{3}$. The volume of pure sulfuric acid that may be produced at Teepak is

$$
\begin{aligned}
\text { Volume } & =(7,014.91 \text { tons } / \mathrm{yr}) /\left(1.54 \text { tons } / \mathrm{yd}^{3}\right) \\
& =4,555.14 \mathrm{yd}^{3} / \mathrm{yr}, \text { or } \\
& =920,019.23 \mathrm{gal} / \mathrm{yr} .
\end{aligned}
$$

\section{B.5.2 Disposal Cost}

The price for the disposal of pure sulfuric acid ranges from $\$ 2.45$ to $\$ 3.06 /$ gal. The disposal cost range is

$$
\begin{aligned}
\text { Minimum cost } & =(\$ 2.45 / \mathrm{gal})(920,019.23 \mathrm{gal} / \mathrm{yr}) \\
& =\$ 2,254,047.11 / \mathrm{yr}, \text { and } \\
\text { Maximum cost } & =(\$ 3.06 / \mathrm{gal})(920,019.23 \mathrm{gal} / \mathrm{yr}) \\
& =\$ 2,815,258.84 / \mathrm{yr} .
\end{aligned}
$$

\section{B.5.3 Taxes}

The city tax is about $\$ 0.025 /$ gal, with a $\$ 0.030 /$ gal hazardous waste tax; the total tax is about $\$ 0.055 /$ gal:

$$
(\$ 0.055 / \mathrm{gal})(920,019.23 \mathrm{gal} / \mathrm{yr})=\$ 50,601.06 / \mathrm{yr} .
$$

Therefore, the disposal cost range, including taxes, is

$$
\$ 2,304,648.17 \text { to } \$ 2,865,859.90 \text {. }
$$

\section{B.5.4 Transportation Cost}

For trips of less than $500 \mathrm{mi}$, the transportation cost is $\$ 914.00$ per load. Since one load equals 4,500 gal, the total number of loads is

$(920,019.23 \mathrm{gal} / \mathrm{yr}) /(4,500.00 \mathrm{gal} / \mathrm{load})=204.45 \mathrm{loads} / \mathrm{yr}$. 
The cost for transportation of 205 loads is

$(\$ 914.00 /$ load $)(205.00$ loads/yr $)=\$ 187,370.00 / y r$

\section{B.5.5 Total Disposal Cost}

The total disposal cost for pure sulfuric acid, including taxes and transportation, is $\$ 2,492,018.17 / \mathrm{yr}$ to $\$ 3,053,229.90 / \mathrm{yr}$.

\section{B.6 SULFUR}

\section{B.6.1 Volume}

The density of solid sulfur is $127.92 \mathrm{lb} / \mathrm{ft}^{3}$ or 1.73 tons/yd $\mathrm{yd}^{3}$. The volume of sulfur produced is

$$
\begin{aligned}
\text { Volume } & =(2,296.49 \text { tons } / \mathrm{yr}) /\left(1.73 \text { tons } / \mathrm{yd}^{3}\right) \\
& =1,327.45 \mathrm{yd}^{3} / \mathrm{yr}
\end{aligned}
$$

\section{B.6.2 Disposal Cost, Including Taxes}

The cost for disposal is $\$ 15.00 / \mathrm{yd}^{3}$. The disposal cost for $1,327.45 \mathrm{yd}^{3} / \mathrm{yr}$ is $\left(1,327.45 \mathrm{yd}^{3} / \mathrm{yr}\right)\left(\$ 15.00 / \mathrm{yd}^{3}\right)=\$ 19,911.76 / \mathrm{yr}$

\section{B.6.3 Transportation Cost}

use is

Each roll-off container holds $20 \mathrm{yd}^{3}$. The number of roll-off containers that Teepak will

$$
\left(1,327.45 \mathrm{yd}^{3} / \mathrm{yr}\right) /\left(20.00 \mathrm{yd}^{3} / \text { container }\right)=66.37 \text { containers } / \mathrm{yr}
$$

The transportation cost for each 20 -yd $\mathrm{d}^{3}$ roll-off container is $\$ 250.00$. The transportation cost for 67 containers is

$(67$ containers $/ y r)(\$ 250.00 /$ container $)=\$ 16,750.00 / y r$. 


\section{B.6.4 Total Disposal Cost}

The disposal cost for elemental sulfur, including taxes and transportation, is $\$ 36,661.76 / y r$.

\section{B.7 SULFURIC ACID NEUTRALIZATION WITH LIMESTONE}

\section{B.7.1 Limestone}

To calculate the amount of limestone needed to neutralize the sulfuric acid produced at Teepak, we note that one molecule of $\mathrm{H}_{2} \mathrm{SO}_{4}$ is neutralized by one molecule of $\mathrm{CaCO}_{3}$. Therefore, the weight of the sulfuric acid produced at Teepak is divided by the molecular weight of $\mathrm{H}_{2} \mathrm{SO}_{4}$; this value is multiplied by the molecular weight of $\mathrm{CaCO}_{3}$. The amount of limestone that Teepak needs each year is

$$
\begin{aligned}
& =\left(7,014.91 \text { tons } \mathrm{H}_{2} \mathrm{SO}_{4} / 98.08 \text { ton mole }\right)\left(100.09 \text { tons } \mathrm{CaCO}_{3} / \text { ton mole }\right) \\
& =7,158.67 \text { tons } \mathrm{CaCO}_{3}
\end{aligned}
$$

The cost for limestone is $\$ 4.30 /$ ton. The total yearly cost for limestone at Teepak is

$$
\begin{aligned}
& =(\$ 4.30 / \text { ton })(7,158.67 \text { tons } / y r) \\
& =\$ 30,782.28 / y r
\end{aligned}
$$

\section{B.7.2 Volume}

The density of gypsum is $144.77 \mathrm{lb} / \mathrm{ft}^{3}$, or $1.95 \mathrm{ton} / \mathrm{yd}^{3}$. The volume of gypsum produced each year is

$$
\begin{aligned}
\text { Volume } & =(12,350.88 \text { tons } / \mathrm{yr}) /\left(1.95 \text { tons } / \mathrm{yd}^{3}\right) \\
& =6,333.78 \mathrm{yd}^{3} / \mathrm{yr} .
\end{aligned}
$$

\section{B.7.3 Disposal Cost, Including Taxes and Fees}

The disposal cost for gypsum is $\$ 15.00 / \mathrm{yd}^{3}$. The cost for disposal of $6,333.78 \mathrm{yd}^{3} / \mathrm{yr}$ is $\left(6,333.78 \mathrm{yd}^{3} / \mathrm{yr}\right)\left(\$ 15.00 / \mathrm{yd}^{3}\right)=\$ 95,006.77 / \mathrm{yr}$ 


\section{B.7.4 Transportation Cost}

The number of $20-\mathrm{yd}^{3}$ containers needed is

$\left(6,333.78 \mathrm{yd}^{3} / \mathrm{yr}\right) /\left(20.00 \mathrm{yd}^{3} /\right.$ container $)=316.69$ containers $/ \mathrm{yr}$.

The transportation cost for each $20-\mathrm{yd}^{3}$ container is $\$ 250.00$. The transportation cost for 317 containers is

$(317.00$ containers/yr $)(\$ 250.00 /$ container $)=\$ 79,250.00 / \mathrm{yr}$.

\section{B.7.5 Total Disposal Cost}

The total disposal and transportation cost, including taxes and the limestone cost, is $\$ 205,039.05 / \mathrm{yr}$. 


\section{APPENDIX C:}

CALCULATIONS USED IN COMPLETING THE MATERIAL BALANCE 


\section{APPENDIX C:}

\section{CALCULATIONS USED IN COMPLETING THE MATERIAL BALANCE}

1. Total Gas Rate

$$
\frac{P V}{R T}=\frac{(1 \mathrm{~atm})\left(400,000 \mathrm{ft}^{3} / \mathrm{min}\right)}{\left(0.73 \mathrm{ft}^{3} \mathrm{~atm} / \mathrm{mole}^{\circ} \mathrm{R}\right)\left(530^{\circ} \mathrm{R}\right)}=1,034 \mathrm{~mole} / \mathrm{min}
$$

$(1,034 \mathrm{~mole} / \mathrm{min})(28.8 \mathrm{lb} /$ mole $)=29,779 \mathrm{lb} / \mathrm{min}$

2. Molar Rate of $\mathrm{CS}_{2}$ Removed

$$
(1,034 \text { mole gas } / \mathrm{min})\left(\frac{100 \text { mole } \mathrm{CS}_{2}}{10^{6} \text { mole gas }}\right)=1,034 \times 10^{-4} \text { mole } \mathrm{CS}_{2} / \mathrm{min}
$$

3. Molar Rate of $\mathrm{H}_{2} \mathrm{~S}$ Removed

$$
1,034\left(\frac{80}{10^{6}}\right)=827 \times 10^{-4} \text { mole } \mathrm{H}_{2} \mathrm{~S} / \mathrm{min}
$$

4. Mass Rate of Sulfur Converted to $\mathrm{H}_{2} \mathrm{SO}_{4}$

$\left(0.1034 \mathrm{~mole} \mathrm{CS}_{2} / \mathrm{min}\right)\left(64 \mathrm{lb} \mathrm{S} / \mathrm{mole} \mathrm{CS}_{2}\right)+(0.0827) 32=9.264 \mathrm{lb} \mathrm{S} / \mathrm{min}$

5. Mass Rate of $\mathrm{H}_{2} \mathrm{SO}_{4}$ Produced

$$
(9.264 \mathrm{lb} \mathrm{S} / \mathrm{min}) \frac{98 \mathrm{lb} \text { acid }}{32 \mathrm{lb} \mathrm{S}}=28.37 \mathrm{lb} \mathrm{acid} / \mathrm{min}
$$

6. Mass Rate of Solution to Biofilter Field

$$
(29,779 \mathrm{lb} \text { gas } / \mathrm{min})(0.43 \mathrm{lb} \mathrm{liq} / \mathrm{lb} \text { gas })=12,804.97 \mathrm{lb} \mathrm{liq} / \mathrm{min}
$$


7. Mass Rate of $\mathrm{H}_{2} \mathrm{O}$ Consumed

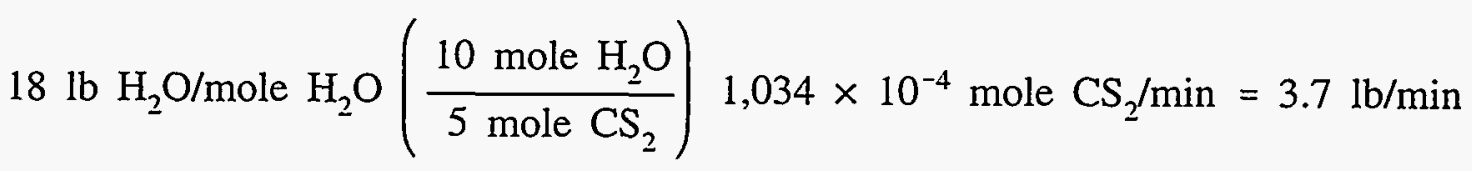




\section{DISTRIBUTION FOR ANL/ESD-30}

\section{Internal}

ANL Technical Publications Service

R. Weeks

S. Juricic (5)

E. Hathaway

M. McIntosh (52)

\section{External}

U.S. Department of Energy Office of Scientific and Technical Information (12) Manager, U.S. Department of Energy Chicago Field Office ANL-E Libraries (2)

ANL-W Library 